\title{
Water Resources of the Ipswich River Basin Massachusetts
}

GEOLOGICAL SURVEY WATER-SUPPLY PAPER 1826

Prepared in cooperation with the Commonwealth of Massachusetts Department of Public Works

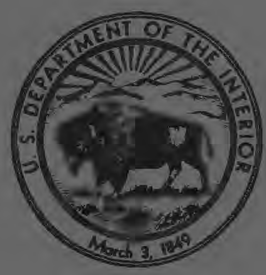




\section{Water Resources of the}

\section{Ipswich River Basin}

\section{Massachusetts}

By E. A. SAMMEL, J. A. BAKER, and R. A. BRACKLEY

GEOLOGICAL SURVEY WATER-SUPPLY PAPER 1826

Prepared in cooperation with the Commonwealth of Massachusetts Department of Public Works

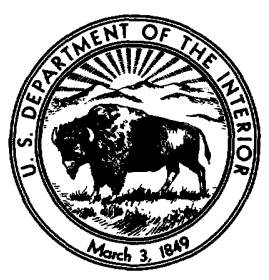




\title{
UNITED STATES DEPARTMENT OF THE INTERIOR
}

STEWART L. UDALL, Secretary

\section{GEOLOGICAL SURVEY}

\author{
William T. Pecora, Director
}

Library of Congress catalog-card No. GS 66-281 


\section{CONTENTS}

Page

Definitions_._.

Abstract

Introduction.

Purpose and scope of the investigation

Previous investigations and reports.

Climate and topography 5

Geologic units and their hydrologic characteristics...... 7

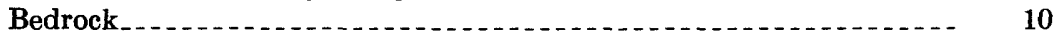

Distribution and characteristics.

Water in the bedrock

Buried valleys._... 13

Unconsolidated deposits.

Till

Ice-contact deposits

Outwash deposits.............. 20

Marine deposits........ 22

Swamp deposits. .

Wind deposits.... 27

Alluvium

Beach and dune deposits. 27

Hydrology ............. 28

Origin and movement of water

Ground water. 29

Recharge

Discharge . .

Natural discharge . .

Artificial discharge

Storage.....

Use

Methods of recovery

Wells _. .

Springs_...

Municipal supply

Domestic supply

Development of ground water in the lower Ipswich River basin _ $\quad 38$

Annual effective recharge.......... 39

Sustained yield and storage..... 41

Feasibility of increasing withdrawal

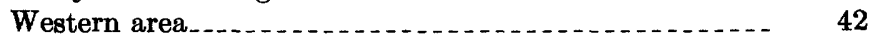

Central area..... 43

Eastern area... 44

Streamflow

General characteristics... 45

Duration of flow 
Hydrology-Continued

Streamflow-Continued

Page

Low-flow frequency

Base runoff . .

Floods _...

Diversion and stream regulation

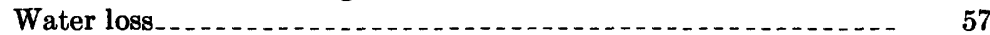

Quality of water

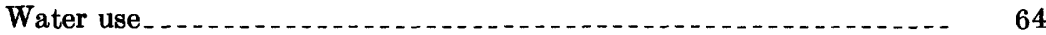

Agriculture, industry, and public supply

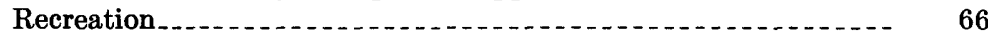

Water-resources development_... 69

Principal conclusions_._.

Selected references.... 76

Index . . . . . . . . 81

\section{ILLUSTRATIONS}

[Plates are in pocket]

Plate 1. Map and section showing surficial geology and depths to bedrock in the Ipswich River basin, Massachusetts.

2. Map showing availability of ground water and location of municipal water supplies, selected wells, and stream-gaging stations in the Ipswich River basin, Massachusetts.

Figure 1. Index map of Massachusetts showing location of the Ipswich River basin. ............ 3

2-16. Graphs showing-

2. Average monthly temperature and precipitation.-

3. Water levels, depths, and yields of wells penetrating

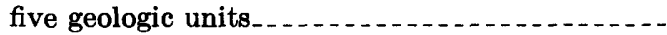

4. Particle-size distributions of ice-contact, outwash,

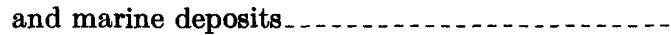

5. Water levels in two wells off Glen Road, Wilmington

6. Water levels in representative wells and cumulative departures from average annual precipitation...

7. Ground-water-level fluctuations, precipitation, and temperature during a period of alternate freezing and thawing.

Page

8. Water use and population growth $\ldots \ldots$

9. Municipal withdrawal of ground water........ 38

10. Estimated frequency limits of effective ground-

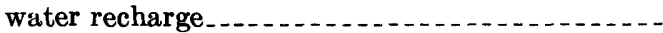

11. Cumulative duration of flows.................

12. Cumulative duration of flows at partial-record

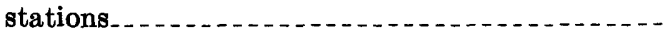

13. Frequency of lowest average discharges at the South Middleton gaging station...............

14. Frequency of lowest average discharges at the Ipswich gaging station........ 
Figore 15. Frequency of annual base runoff

16. Frequency of annual floods..... 55

17. Diagram showing relative amounts of selected chemical constituents in wells penetrating unconsolidated deposits

18. Diagram showing relative amounts of selected chemical constituents in wells penetrating bedrock ..........

19. Graphs showing annual withdrawals of water and popula-

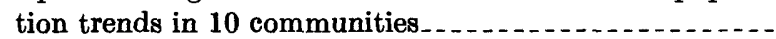

20. Graph showing per capita use of water in Hamilton, Reading, and Wilmington.......

21. Diagram showing average annual precipitation, evapotranspiration, runoff, and use of water.............

22. Graph showing frequency of lowest precipitation during the growing season at Middleton

\section{TABLES}

Table 1. Geologic units in the Ipswich River basin ...........

2. Hydrologic character of geologic units in the Ipswich River basin

3. Particle-size analyses of geologic units in the Ipswich

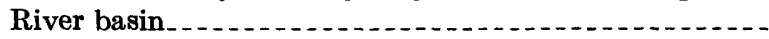

4. Annual precipitation, runoff, and base runoff in the Ipswich River basin

5. Chemical constituents of ground water in the Ipswich River basin

6. Summary of chemical analyses of water from wells and springs in the Ipswich River basin ...............

7. Concentrations of iron and manganese in samples of water from the Ipswich River.

8. Statistics relating to municipal water supplies withdrawn in the Ipswich River basin

\section{DEFINITIONS}

Definitions given here are not necessarily complete; they are intended as minimum explanations of use in this report.

Aquifer. A rock formation or geologic unit that is water bearing. Also called ground-water reservoir.

Aquifer, confined. An aquifer in which water in confined by relatively impermeable boundaries, which are generally the upper and lower surfaces of the aquifer. The confined water is under hydrostatic pressure which can cause it to rise in wells to a level above the top surface of the aquifer. The terms artesian aquifer and artesian water refer to these conditions. 
Aquifer, semiconfined. An aquifer at least one of whose confining boundaries is sufficiently permeable to permit some movement of water across the boundary into or out of the aquifer.

Aquifer, unconfined. An aquifer whose upper surface is sufficiently permeable to allow the free rise and fall of the water table. Also called a water-table aquifer.

Bedrock. The consolidated rock of the earth's crust.

Capillary fringe. The zone above the water table containing water in capillary openings.

Climatic year. The annual period beginning May 1 and ending April 30. Used as computation period for low-flow analyses; designated by the calendar year in which it begins.

Discharge, ground-water. Removal of water from an aquifer by evapotranspiration, natural flow to streams, or by pumping.

Discharge, surface-water. Rate of flow of a surface stream in terms of volume per unit of time. Expressed in this report as cubic feet per second or million gallons per day.

Diversion. In this report, water disposed of, or the disposal of water, outside the drainage basin in which it originates.

Drainage basin. An area occupied by a drainage system into which all surface waters within the area discharge. The boundary between two drainage basins is called a drainage divide.

Drawdown. The lowering or the amount of lowering of the water level in a well is the result of withdrawal of water.

Evapotranspiration. Combined discharge of water to the air by direct evaporation and plant transpiration.

Geologic unit. A group of rocks having common or closely related characteristics. Geologic units in the Ipswich River basin are classified largely according to mode of origin.

Ground water. Water in rock materials beneath the surface of the earth. Ground water is distinguished from soil moisture in this report. See Storage.

Hydraulic gradient. A pressure gradient or the slope of the free upper surface of the zone of saturation (water table). In an aquifer it is the change of pressure head per unit of distance of fiow in a given direction, commonly expressed in feet per mile.

Hydrograph. A graph showing changes of level or other property of water with respect to time.

Partial-record station. A site where limited streamflow data are collected systematically over a period of years for use in hydrologic analyses.

Permeability. The capacity of rock materials to transmit fiuid. Permeability depends largely on the shape and size of pore spaces and their interconnections ; in general, the larger the openings, the greater is the permeability.

Coefficient of permeability. As used by the Geological Survey, the rate of flow of water in gallons per day through a cross-sectional area of 1 square foot under unit hydraulic gradient and at a temperature of $60^{\circ} \mathrm{F}$. For field use the temperature is neglected and the field coefficient expresses the flow of water under prevailing field conditions. Expressed in units of gallons per day per square foot.

$p H$. A symbol used in denoting the acidity or alkalinity of solutions. $\mathrm{pH}$ values range from 0 to $14 ; 7$ indicates a neutral solution; numbers greater than 7 indicate alkalinity, and numbers less than 7 indicate acidity. 
Pleistocene. An epoch of the geologic time scale occuring just prior to the Recent epoch. Commonly referred to as the glacial epoch or ice age.

Porosity. The ratio of the volume of openings (pores) to the total volume of a rock. If pores are interconnected, the porosity determines the maximum capacity of a rock to accept and store water. Because pore spaces, although numerous, may be very small or poorly connected, a high porosity does not necessarily indicate a high permeability.

Recession curve. A hydrograph showing the decreasing rate of runoff or groundwater discharge following a period of rain or snowmelt.

Recharge. Addition of water to an aquifer by infiltration of precipitation through the soil, by seepage from streams or other bodies of surface water, by flow of ground water from another aquifer, or by pumpage of water into the aquifer through recharge wells; also, the water added by these processes.

Runoff. That part of precipitation that appears in surface streams. It is the same as streamflow unaffected by artificial diversions, storage, or other works of man in or on the stream channels (Langbein and Iseri, 1960, p. 17). On the basis of speed of appearance after rainfall or melting snow, runoff may be classified as direct runoff, which is directly associated in time with causative rainfall or melting snow, and base runoff, which is the sustained or fair weather flow. On the basis of source, runoff may be classified as surface runoff, which travels over the soil surface to the nearest stream channel, ground-water runoff, which is derived by seepage from the ground-water body, and storm seepage, which is derived by seepage from shallow, perched groundwater bodies above the main ground-water body. Direct runoff ordinarily consists of surface runoff and storm seepage. Base runoff consists largely of ground-water runoff but may also include surface runoff. For example, in the Ipswich River basin the base runoff at times consists only of ground-water runoff, but at other times it may include surface runoff from water temporarily stored on the swamps.

Sorting. In a sediment, a measure of the range of the size distribution on either side of the average.

Sorting coefficient. In this report a figure representing sorting in a given sample; determined by the expression: $S_{0}=\sqrt{Q_{1} / Q_{3}}$, where $Q_{1}$ is the particle size greater than that of 75 percent of the sample, and $Q_{3}$ is the size greater than that of 25 percent of the sample. In a perfectly sorted sample, all particles are the same size and $S_{0}=1$.

Specific capacity. The rate of discharge from a well per unit of drawdown, expressed as gallons per minute per foot.

Specific yield. The quantity of water that a fully saturated rock will yield by gravity drainage; expressed as a percentage which is the ratio of (1) the volume of water yielded to (2) the volume of the rock.

stage. The height of a water surface above an established datum plane; often used interchangeably with gage height.

Storage. Water detained in a drainage basin by natural or artificial means. In the Ipswich River basin, storage is largely natural and consists of (1) soil moisture, water retained in the soil and available for use by vegetation, (2) surface-water storage, water temporarily impounded in depressions in the earth's surface such as ponds, swamp surfaces, and stream channels, (3) ground-water storage, water in the saturated zone of rock materials and in the unsaturated zone between the water table and the soil zone, and (4) miscellaneous categories such as the small amounts of water stored by vegetation, and others. 
Stratigraphy. That part of the descriptive geology of the area which pertains to the character, thickness, sequence, and age of the rocks.

Surface water. Water on the surface of the earth.

Thiessen method. A graphic means of integrating precipitation records from several stations in order to estimate the average precipitation over an area.

Transmissibility. The capacity of a formation to transmit water. Coefficient of transmissibility. The rate of flow of water through a vertical strip of the aquifer 1 foot wide and extending the full saturated thickness under a hydraulic gradient of 100 percent ( $1 \mathrm{ft}$. per $\mathrm{ft}$.). Expressed in gallons per day per foot. Also the arithmetical product of the coefficient of permeability and the saturated thickness of an aquifer.

Unconsolidated rocks. The surficial materials that overlie bedrock nearly everywhere in the river basin. Composed of discrete particles that range in size from clay to boulders.

Water loss. The difference between the average precipitation over a drainage basin and the water yield from the basin for a given period. It is assumed that over a sufficiently long period of time the water loss is equal to the average evapotranspiration.

Water table. The free upper surface of a zone in which openings in the rocks are fully saturated with water under hydrostatic pressure. In a well penetrating a water-table aquifer, the water stands at a level which represents the position of the water table at that place at a given time.

Water year. The annual period beginning October 1 and ending September 30. The water year is designated by the calendar year in which it ends. 


\title{
WATER RESOURGES OF THE IPSWICH RIVER BASIN MASSACHUSETTS
}

\author{
By E. A. Sammel, J. A. Baker, and R. A. Brackley
}

\begin{abstract}
Water resources of the Ipswich River basin are at present (1960) used principally for municipal supply to about 379,000 persons in 16 towns and cities in or near the river basin. By the year 2000 municipal use of water in this region will probably be more than twice the current use, and subsidiary uses of water, especially for recreation, also will have increased greatly.

To meet the projected needs, annual pumpage of water from the Ipswich River could be increased from current maximums of about $12 \mathrm{mgd}$ (million gallons a day) to about $45 \mathrm{mgd}$ without reducing average base flows in the river, provided that the increased withdrawals would be restricted to periods of high streamflow. In addition, considerably more pumpage could be derived from streamflow by utilizing base-flow discharge; however, the magnitude of such use could be determined only in relation to factors such as concurrent ground-water use, the disposal of waste water, and the amount of streamflow required to dillute the pollution load to acceptable levels. Under present conditions, little or no increase in diversion of streamflow would be warranted in the upstream parts of the basin during the summer and early fall of each year, and only a moderate increase could be made in the lower reaches of the stream during the same period.

Annual rainfall in the basin averages about 42.5 inches, and represents the water initially available for use. Of this amount, an average of about 20.5 inches is returned to the atmosphere by evapotranspiration. The remainder, about 22 inches, runs off as streamflow in the Ipswich River or is diverted from the basin by pumpage. The average annual stream runoff, amounting to about 47 billion gallons, is a measure of the water actually available for man's use. The amounts of water used by municipalities in recent years are less than 10 percent of the available supply.

Large supplies of ground water may be obtained under water-table conditions from the stratified glacial drift that forms the principal ground-water reservoir of the basin. Stratified drift deposits fill valleys in about 31 percent of the basin. Thicknesses of the deposits are generally less than 50 feet, but at places may be as great as 200 feet.
\end{abstract}

Between 1931 and 1960 recoverable annual recharge to stratified drift aquifers averaged about 10 inches, equal to $42 \mathrm{mgd}$. The least possible recharge during any of these years was probably more than $41 / 2$ inches, or $25 \mathrm{mgd}$. Therefore, ground-water withdrawals from the basin could be sustained at a rate at least five times greater than the 1960 rate of $4.9 \mathrm{mgd}$. In the lower Ipswich basin, withdrawal of ground water could be sustained at a rate eight or nine times greater than the 1960 rate of $1.86 \mathrm{mgd}$. There are 1 or more favorable sites for 
further exploration for ground water in each of the 10 communities that occupy the major part of the river basin. Small but reliable supplies of ground water for domestic use may be withdrawn from bedrock almost anywhere in the basin.

Ground-water levels show no long-term trend since 1939, and although large fluctuations in water levels occur during each year, the ground-water reservoir at most places in the Ipswich River basin is replenished annually to its full capacity. During parts of most years potential recharge is unable to enter the already-saturated ground-water reservoirs, and most of this "rejected recharge" enters streams as surface runoff.

The chemical quality of both ground and surface water is generally satisfactory for most uses, although excessive concentrations of iron and manganese occur locally, and at places the hardness of the water is objectionable.

The surface- and ground-water resources of the basin are closely related. Because most areas favorable for further development of ground water are adjacent to stream channels, large increases in the withdrawal of ground water during low-flow periods will result in reductions of streamflow. The magnitude of the effect will be strongly dependent on whether the ground water withdrawn is diverted from the basin, wasted to a stream from a central point, or returned to the ground at numerous points within the basin. Conversely, a reduction of streamflow by pumping directly from stream channels during low-flow periods may in turn reduce the amount of water available to wells adjacent to the channels. Such measures as swamp drainage, channel dredging, diversions of streamflow, or pumpage of ground water to divert potential base flow would tend to further reduce low streamflows, and could reduce ground-water withdrawals at downstream points.

\section{INTRODUCTION}

\section{PURPOSE AND SCOPE OF THE INVESTIGATION}

The Ipswich River basin, an area of 155 square miles in Middlesex and Essex Counties, is in a region which is undergoing rapid urbanization (fig. 1). Communities in this a rea have absorbed, and will continue to absord, the burgeoning population of metropolitan Boston. The rapid growth of these communities has intensified old water problems and created new ones. Those responsible for planning and development in the region are confronted not only by the recurring problem of where to get new supplies of water to meet increasing demand, but also by the twofold problem of anticipating the effects of land-use changes upon water resources and of resolving conflicts of interest among users of the land and water resources.

In order to provide data upon which solutions to many of the water problems could be based, investigation of the water resources in the Ipswich River basin was begun in 1955 by the U.S. Geological Survey in cooperation with the Massachusetts Department of Public Works. Specific objectives were (1) to determine the elements of geology and hydrology involved in a program proposed for drainage of wetlands in Wilmington, Reading, and North Reading, (2) to define the relationship of surface and ground water to the Reading municipal water supply, (3) to analyze streamflow data from two gaging stations on 


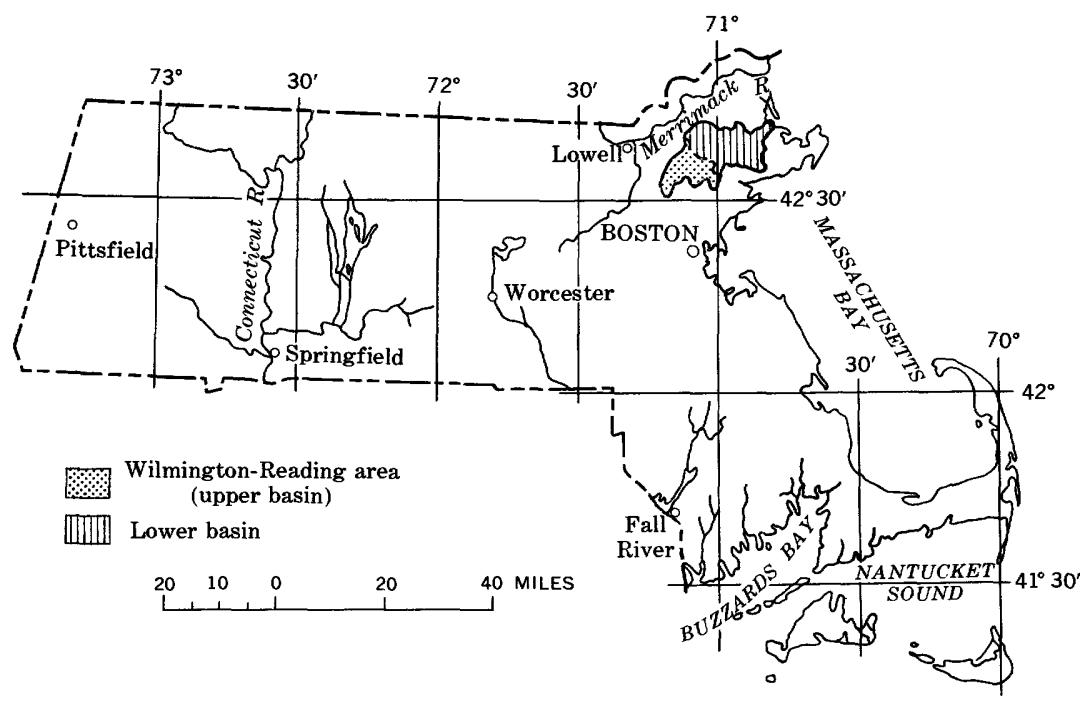

Frgure 1.-Location of the Ipswich River basin.

the Ipswich River as a means of estimating base flow and determining the low-flow characteristics of the river, and (4) to decribe the geohydrologic conditions in the lower Ipswich River basin.

The investigation was carried out under the general direction of O. M. Hackett, former district geologist, Branch of Ground Water, U.S. Geological Survey. Assisting with the fieldwork during the summers of $1955-58$ were Henry G. Healy, Gordon S. Bird, Joan Canzanelli, John K. Colby, Richard J. Hecht, and Edward A. Sossen.

Analyses of ground water were made by the Branch of Quality of Water, Albany, N.Y., under the direction of Felix Pauszek. Analyses of rock materials for particle-size distribution and hydrologic properties were made in the hydrologic laboratory of the Branch of Ground Water, Denver, Colo., under the direction of A. I. Johnson.

Surface-water work in support of the investigation was performed by personnel of the Branch of Surface Water of the Geological Survey under the direction of C. E. Knox, District Engineer, Boston, Mass. Miscellaneous measurements of streamflow were made by R. A. Brackley, and interpretations of low-flow data were made by R. A. Brackley and C. E. Knox.

The Branch of Regional Geology in New England, U.S. Geological Survey, furnished preliminary surficial geologic maps of the Wilmington and Georgetown quadrangles by R. O. Castle and N. P. Cuppels, respectively, and the Reading and Salem quadrangles by R. N. Oldale. Surficial geology in the South Groveland quadrangle 
was mapped by H. G. Healy, Branch of Ground Water, and the Ipswich and Marblehead North quadrangles by the senior author. Seismic data were obtained and interpreted by C. R. Tuttle of the Branch of Regional Geology in New England and by Weston Geophysical Engineers, Inc., Weston, Mass. Seismic reports by Weston Geophysical Engineers were made available through the courtesy of the Weston corporation, the Massachusetts Department of Public Works, and the towns of Danvers and Ipswich. The writers gratefully acknowledge the help of well owners, well drillers, consultants, and town and city officials.

\section{PREVIOUS INVESTIGATIONS AND REPORTS}

Major geologic features of the Ipswich River basin are described in a report on the geology of Massachusetts and Rhode Island by Emerson (1917). The report includes a map showing the distribution of bedrock formations in the two States. Reports on the geology of Essex County by Sears (1905) and Clapp (1921) include geologic maps showing bedrock and some glacial features. A report by Chute and Nichols (1941) describes the geology of the coastline of northeastern Massachusetts, including the coastal section of the Ipswich River basin.

Two reports dealing with water resources are of general interest. The first, a report on land and water resources of the New EnglandNew York region by the New England-New York Inter-Agency Committee (1955), contains a chapter on the Massachusetts Coastal Region. The second, by Crosby (1937), describes the occurrence of ground water in relation to buried valleys in northeastern Massachusetts.

Most of the basic ground-water data collected in the lower Ipswich River basin are available in a report by Samuel and Baker (1962). This report includes records of 733 wells or groups of wells and test holes, logs of 242 wells and test holes, chemical analyses of 21 water samples, periodic measurements of water levels in 36 wells, and pumpage of ground water for public supply in 5 municipalities. Basic data from the Wilmington-Reading area are available in a similar report by Baker and Sammel (1961). Both reports may be obtained from the office of the U.S. Geological Survey, Water Resources Division, 2300 John Fitzgerald Kennedy Federal Building, Boston, Mass., 02203.

Stream discharges measured at two gaging stations on the Ipswich River are published by the U.S. Geological Survey in a continuing series of Water-Supply Papers entitled "Surface Water Supply of the United States." 
Detailed results of the investigation of ground-water conditions in the upstream portion of the drainage basin are given by Baker, Healy, and Hackett (1964).

\section{CLIMATE AND TOPOGRAPHY}

The climate of the Ipswich River basin is typical of humid areas in the north-temperate latitudes. Temperature extremes in the basin are moderated by proximity to the ocean, and, on the other hand, extremes of precipitation are increased by the seasonal hurricanes that are common to the Atlantic coast.

Average annual precipitation for the period 1931-58 in the Ipswich River basin is 42.47 inches, as computed by the Thiessen method. The average is computed from records of precipitation obtained at stations in Beverly, Ipswich, Middleton, North Andover, Peabody, Reading, and Wilmington. From snowfall records at Ipswich, Middleton, and Haverhill it is estimated that an average of slightly more than 50 inches of snow, an amount roughly equivalent to 5 inches of rainfall, falls in the basin annually. Thus an abundant supply of water is available in the basin each year, and, as is shown in figure 2 , the precipitation is distributed with remarkable uniformity throughout the year. At Middleton, for example, the difference between average precipitation for February, the driest month (3.13 in.), and the average for November, the wettest month (3.93 in.), is slightly less than one inch. However, maximum monthly precipitation has amounted to more than four times the average values for some months of the year, mainly as the result of fall hurricanes and a few severe winter storms.

In spite of the nearly uniform distribution of precipitation through the year, there is a marked seasonal change in hydrologic conditions which is primarily due to the annual temperature cycle (fig. 2). During the annual rise and fall of temperature, the growing season for vegetation is the period between the last freezing temperatures in the spring and the first frost in the fall. During the growing season, which averages nearly 180 days between mid-April and mid-October, most precipitation is intercepted and evaporated by plants, and as a result little or no recharge reaches the deeper ground-water bodies. The hydrologic effects during this season are readily apparent in the decline of ground-water levels and in drastic reductions of streamflow.

The topography of the Ipswich River basin, although highly irregular on a small scale, is sufficiently uniform to have little effect on temperatures and precipitation. The basin is in the seaboard lowland (Fenneman, 1938, p. 370-373), and is characterized by low rounded 


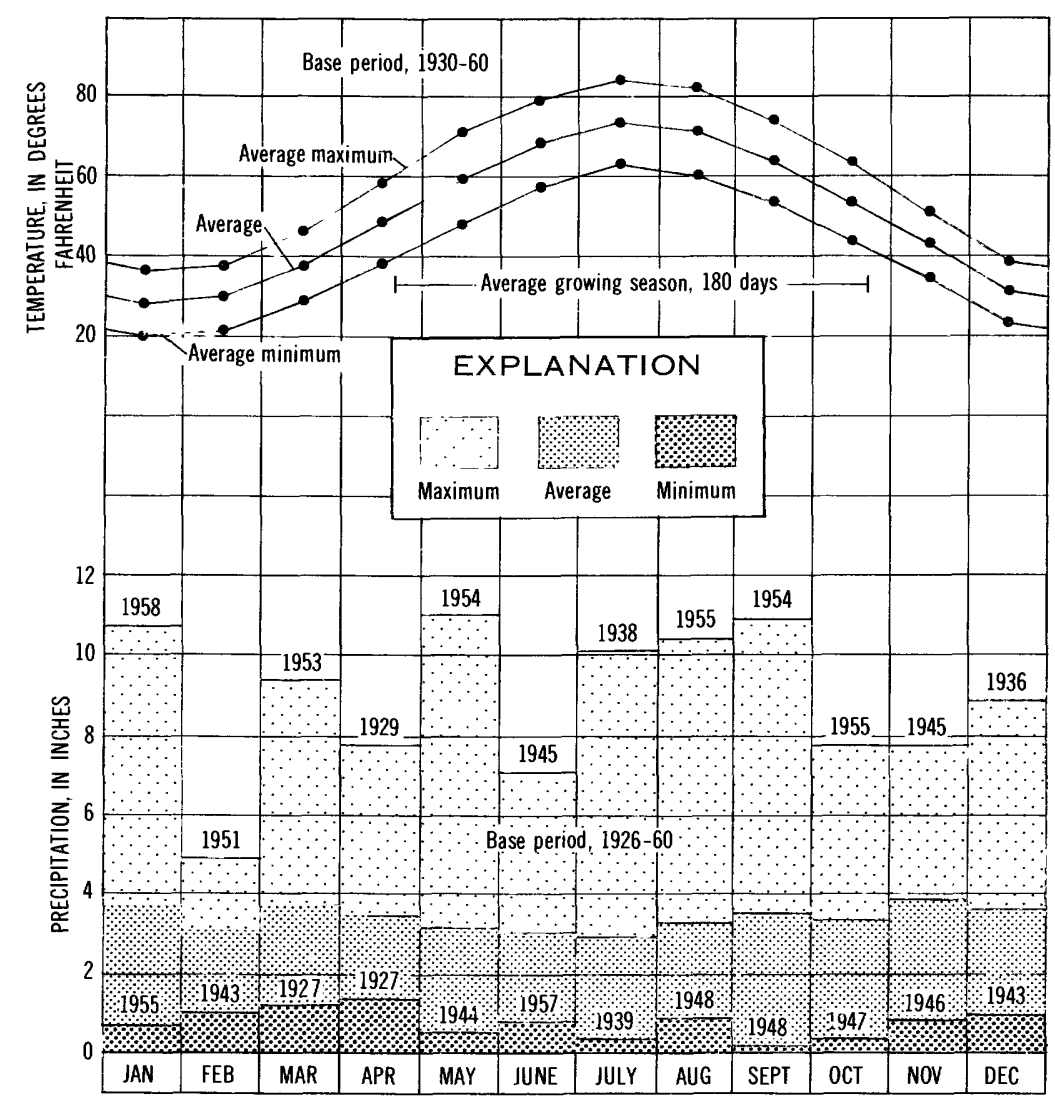

FiguRE 2.-Average monthly temperatures at Haverhill, and average monthly precipitation at Middleton.

hills surrounded by swamps. The summits of most hills lie below 300 feet, although Mills Hill in North Andover and Holt Hill in Andover have altitudes of 405 and 420 feet respectively. The lowlands, in which low mounds, ridges, terraces, and alluvial flats are interspersed with swamps, range in altitude from sea level to about 140 feet. Nearly one-fifth of the land surface is flooded during part of each year, and many of the largest lowland areas possess no clearly defined drainage pattern. Small ponds, and lakes, the largest of which is Wenham Lake in Wenham and Beverly, occupy numerous depressions in the swampy lowland surfaces.

The Ipswich River, which descends only about 115 feet in its 35-mile course, flows for much of its length through the nearly level freshwater marshes. Tidal marshes border the river below a dam at 
Ipswich, and from this point to the sea, a distance of $31 / 2$ miles, the river is an estuary.

The effect of precipitation in the basin is modified by the differences in the permeability of the glacial till in the uplands and of the stratified drift and swamp deposits in the lowlands. Precipitation runs off rapidly from the semipermeable materials in the uplands and only a small part is recharged to the glacial till. In the lowlands vast quantities of precipitation infiltrate the permeable sediments and are stored and released slowly throughout the year, a condition making these areas not only the major sources of stream base flow but also the major ground-water reservoirs.

\section{GEOLOGIC UNITS AND THEIR HYDROLOGIC CHARACTERISTICS}

The Ipswich River basin is underlain by consolidated (bedrock) and unconsolidated rocks. (See table 1.) Bedrock consists of a variety of igneous and metamorphic rocks whose infiltration properties, storage capacities, and water yield are relatively uniform. For the purpose of this report bedrock is considered as a single geologic unit. The unconsolidated rocks are subdivided according to origin into seven geologic units which differ greatly in their hydrologic properties (table 2). Areal relationships of the surficial geologic units and locations of bedrock outcrops are shown in plate 1. 


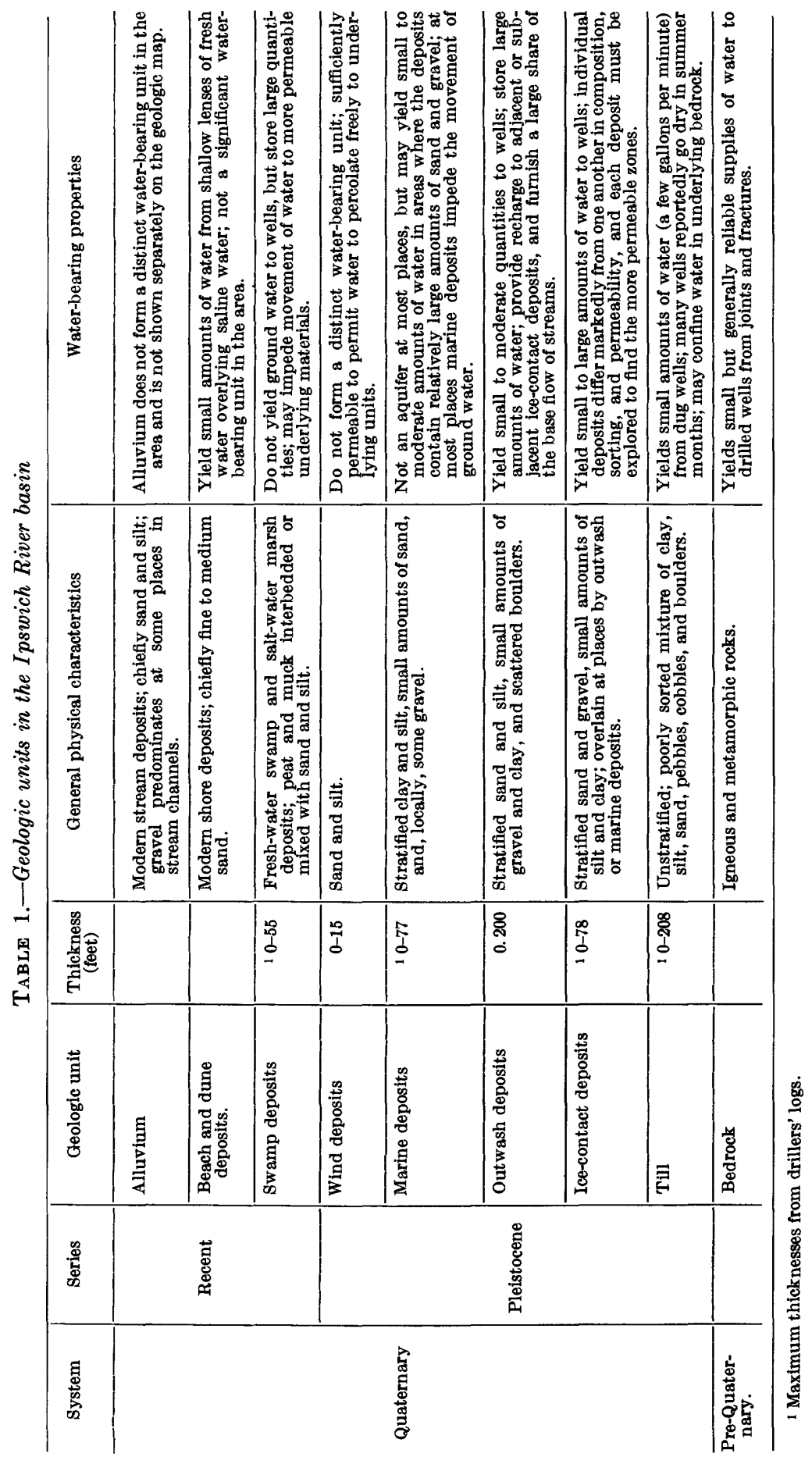




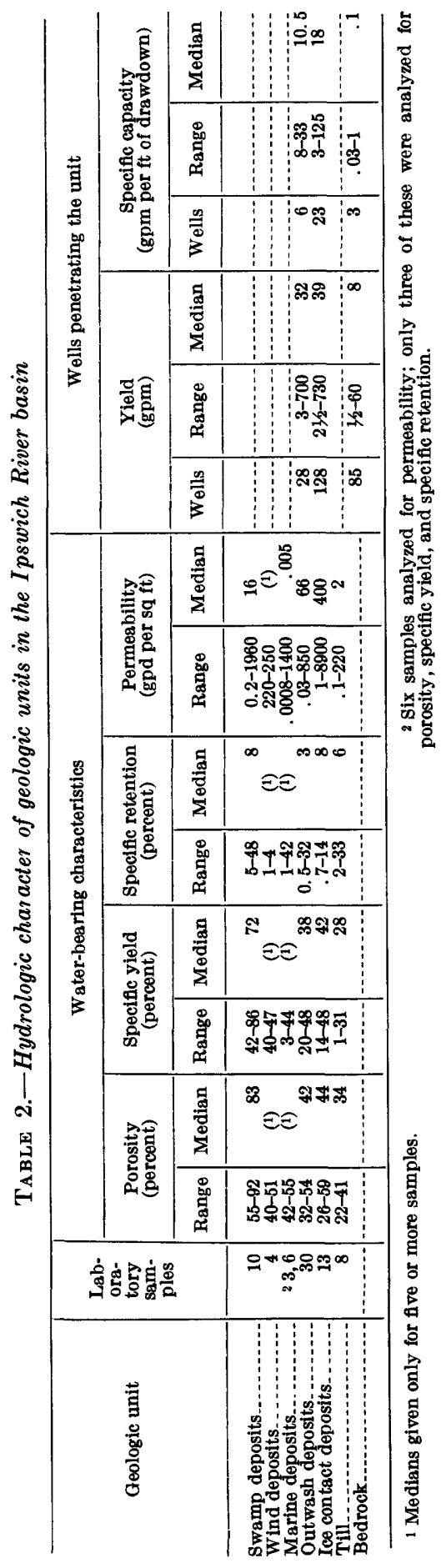




\section{BEDROCK}

\section{DISTRIBUTION AND CHARACTMRISTICS}

The bedrock formations in the Ipswich River basin consist of igneous and metamorphic rocks ranging in age from Precambrian to Triassic. These rocks have been described by Sears (1905), Emerson (1917), Clapp (1921), and LaForge (1932). As described by Emerson, the principal rock types are diorite, granite, gabbro, gneiss, and quartzite. Subordinate rock types include schist, syenite, diabase, and pegmatite. The rocks have been folded, fractured, and, at places, faulted; they show evidence of a northeast-southwest structural trend.

Bedrock is exposed principally on hills and ridges, but also crops out from place to place in the valleys and along the coastal marshes. Over most of the area, the irregular, knobby bedrock surface is mantled by unconsolidated deposits.

\section{WATPER IN THE BEDROCK}

Ground water in the bedrock occurs chiefly in joints or fractures, which in general are narrow planar openings. Where the joints and fractures have been enlarged by weathering, the openings may be as much as several inches wide and spaced from less than an inch to as much as 4 feet apart. The joints intersect each other and therefore may be interconnected over a considerable area. They probably decrease in number and size with depth, however, and occupy only a small proportion of the total volume of the bedrock. As a result, the porosity, specific yield, and permeability of the bedrock generally are low.

The bedrock is a source of small but generally reliable supplies of ground water throughout the area. Because of its low porosity and correspondingly low storage capacity, it is of little importance as a reservoir; rather, the joints in the bedrock serve principally as conduits which transmit water from overlying materials to wells that intersect the joints. Wells intersecting these joints yield water at rates determined either by the permeability of the bedrock or by the permeability of overlying deposits, whichever is smaller. Some joints are isolated, and others are connected only to an exposed bedrock surface or to dry unconsolidated deposits. If a well were to penetrate only such joints, the water supply would fail whenever the small quantity of ground water stored by the joints was exhausted.

Ground water in the bedrock commonly occurs under confined (artesian) conditions; and, as a result, water in most wells in bedrock rises above the depth at which it is first found. Ordinarily, the walls of the joints serve as the confining layers, but at some places impermeable unconsolidated deposits overlie the bedrock surface and act as con- 
fining layers. Less commonly, the water in bedrock occurs under unconfined (water-table) conditions in places where overlying materials are either absent or are very permeable.

At most places where observations could be made, water levels in wells in bedrock were higher than the bedrock surface. Depths to water are generally greater in wells on hills than in the valleys. The maximum depth to water, 153 feet, was measured in a well (North Andover 61) on the summit of Boston Hill, one of the highest points in the area.

The depth at which water is reached in a well in bedrock is no index to the depth at which a nearby well will reach water. The depth at which water is found in a well depends on where a water-bearing joint is first intersected. One well may intersect such a joint only a few feet below land surface, whereas a nearby well may be drilled to a depth of many feet before doing so.

Because of the great variety in size, spacing, and attitude of the joints, neither the depths nor the yields of wells in bedrock can be predicted accurately. However, most wells yield at least a few gallons per minute, enough for domestic use, at depths between 50 and 150 feet. Data on depths to water, yields, and static water levels for wells in bedrock in the Ipswich River basin are summarized in figure 3.

Because of the low permeability of the bedrock, the specific capacities of wells are expected to be small. The reported specific capacities of three wells for which information is available are about $1,0.1$, and $0.03 \mathrm{gpm}$ (gallons per minute) per foot of drawdown. These figures are low compared with specific capacities of wells in unconsolidated deposits.

Bedrock is regarded in this report as a single geologic unit largely because the hydrologic properties of bedrock appear to be relatively uniform throughout the basin. However, the relationship of bedrock to runoff and evapotranspiration differs greatly from place to place, depending largely on the bedrock topography. In uplands of the basin in which bedrock is near to or exposed at the surface, the amount of ground-water storage per unit of surface area is minimum; and a large proportion of the potential recharge is rejected each year. The amount of direct runoff per unit of precipitation is probably at its maximum in these upland areas. Little is known about the rates at which water enters and leaves the bedrock anywhere in the Ipswich River basin, but the evidence indicates that both recharge and discharge occur at small and relatively uniform rates during most of the year. Annual changes in amounts of storage are probably small, and it is assumed that water fills nearly all the available storage volume in bedrock during most of each year. 
WATER, IPSWICH RIVER BASIN, MASSACHUSETTS
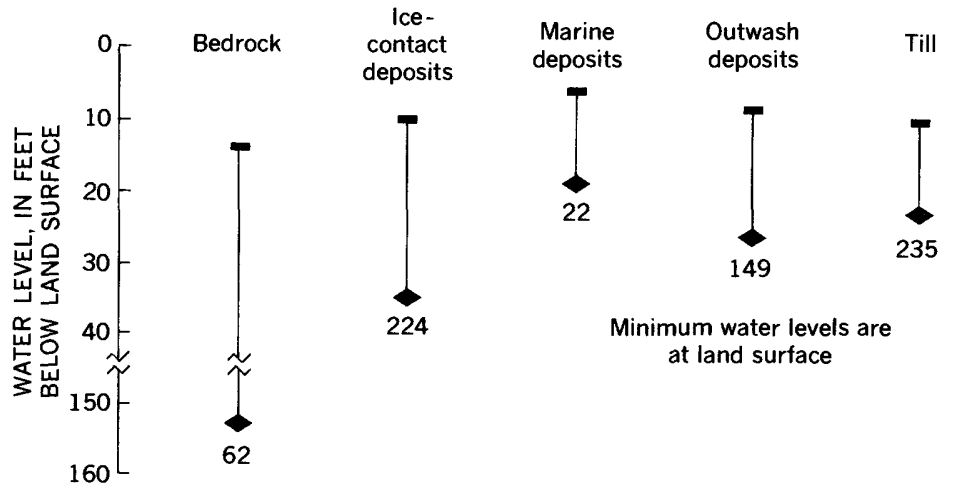

Minimum water levels are at land surface
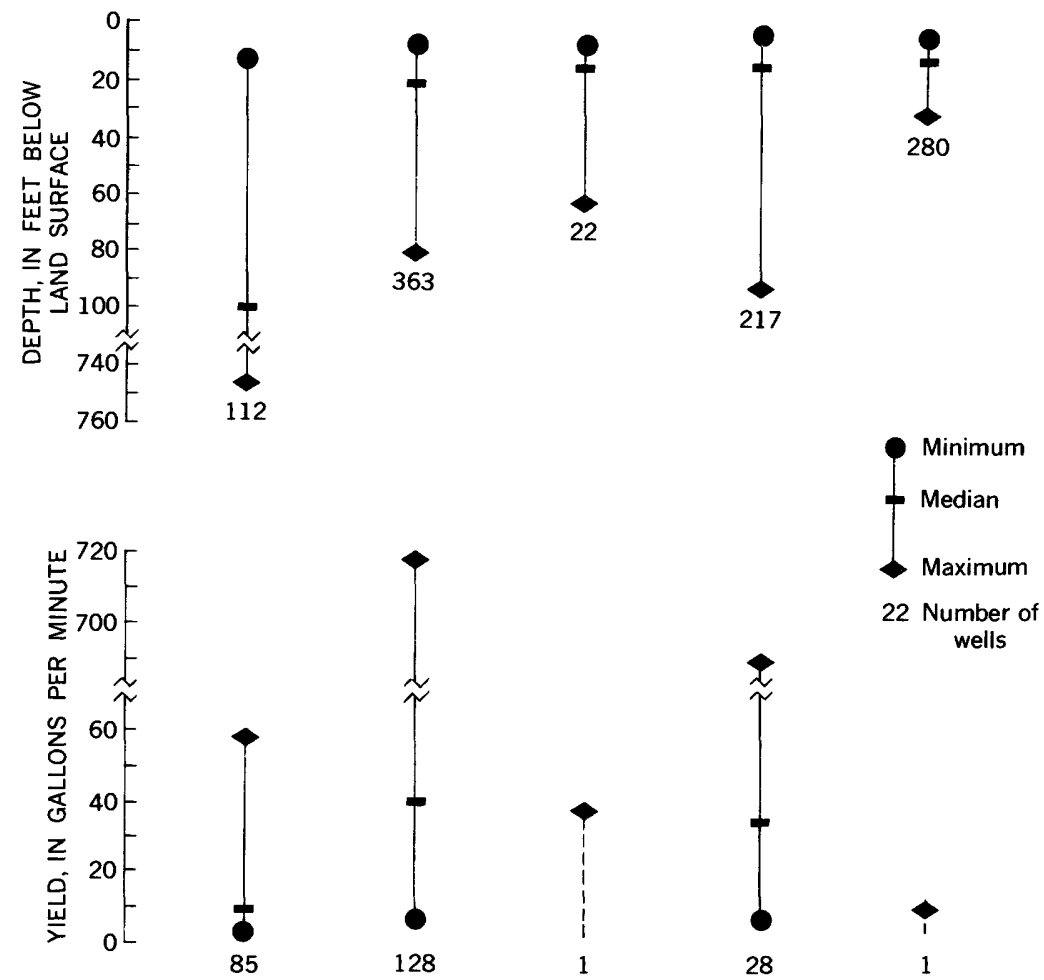

FIGURE 3.-Ranges and medians of water levels, depths, and yields of wells penetrating five geologic units. 


\section{BURIFD VALLEYS}

Former stream valleys deeply incised into bedrock have been traced through portions of the Wilmington-Reading area (Baker and others, 1964). These valleys are now partly filled with stratified sediments which form a large part of the ground-water reservoir for the upper Ipswich River basin. In the basin above South Middleton, the ancient bedrock valley system coincides at places with the present drainage system of the Ipswich River. Altitudes of the bedrock surface commonly are 20-30 feet below sea level, and the bedrock valleys range from 200 feet to perhaps 2,000 feet in width. Depths to bedrock or refusal in wells, test borings, and seismic exploration are shown on the geologic map (pl. 1).

In the Ipswich River basin downstream from South Middleton, known depths to bedrock are too scattered to permit the continuous tracing of buried valleys. At a number of places the bedrock surface is many feet below sea level, and the pattern of these locations suggests that there is more than one preglacial valley crossing the present valley of the lower Ipswich River.

Some of the lowest known altitudes of bedrock surfaces in the lower Ipswich River basin are given in the following tables; the locations of the wells and seismic lines are shown in plates 1 and 2 , respectively.

Wells and Test Borngs

\begin{tabular}{|c|c|c|}
\hline Well & Location & $\begin{array}{l}\text { Altitude of bed- } \\
\text { rock surface (ft } \\
\text { below mean sea } \\
\text { level) }\end{array}$ \\
\hline $\begin{array}{l}\text { Hamilton } 100 \\
\text { Ipswich } 159\end{array}$ & $\begin{array}{l}\text { Idlewood Brook at Ipswich River, Hamilton- } \\
1 / 2 \text { mile southwest of Heartbreak Hill, Ips- }\end{array}$ & $\begin{array}{r}15 \\
>44\end{array}$ \\
\hline $183 \ldots$ & $\begin{array}{l}\text { wpswich River east of Mill Road, Ipswich-- } \\
\text { Ipswich River east of Palmer State Park, } \\
\text { Ipswich. }\end{array}$ & $\begin{array}{r}>40 \\
37\end{array}$ \\
\hline $89-1-2-1$ & Miles River at Sagamore Road, Ipswich & 7 \\
\hline & $\begin{array}{l}\text { Eagle Hill River southeast of Eagle Hill, } \\
\text { Ipswich. }\end{array}$ & 7 \\
\hline Topsfield 7 & $\begin{array}{l}\text { Ipswich River at Rowley Bridge, Topsfield - - } \\
\text { Massachusetts Audubon Society reserva- }\end{array}$ & $\begin{array}{l}28 \\
45\end{array}$ \\
\hline Wenham 15_ & Pleasant Pond, Wenham & 36 \\
\hline
\end{tabular}

Seismic Lines

\begin{tabular}{l|r}
\hline Location & $\begin{array}{c}\text { Lowest bedrock } \\
\text { altitude (ft below } \\
\text { mean sea level) }\end{array}$ \\
\hline Ipswich River at Route 114, Middl eton & 70 \\
Ipswich River at Middleton Colony, Middleton & 65 \\
$1 / 2$ mile northeast of Putnamville Re servoir, Danvers. & 40 \\
\hline
\end{tabular}




\section{UNCONSOLIDATED DEPOSITS}

Unconsolidated deposits in the lower Ipswich River basin are composed largely of debris remaining from the passage over the area of one or more ice sheets during the Pleistocene Epoch. In addition to the glacial drift (a general term for all deposits of glacial origin), there are minor amounts of wind laid deposits of Pleistocene age, and swamp deposits and alluvium of Recent age. The glacial drift includes deposits of till (ice-laid drift) and stratified drift (water-laid drift). The stratified drift is subidivided further, according to its environment of deposition, into ice-contact, outwash, and marine deposits.

Not all unconsolidated deposits in the Ipswich River basin can be classified precisely. Locally, till and ice-contact deposits are intimately associated and, in some places, are difficult to distinguish from one another. The youngest ice-contact deposits are transitional to the oldest outwash deposits, and the youngest outwash deposits grade into marine deposits and the alluvium. Nevertheless, at most places the unconsolidated deposits differ from each other in form, physical characteristics, and water-bearing properties.

Ground water in the unconsolidated deposits occurs in intergranular openings (voids between the particles). The porosity of the rock materials depends principally on the shape and arrangement of the constituent particles and on the degree of sorting. The permeability depends on the size, shape, and interconnection of the openings. Finegrained materials, such as clay and silt, have many very small openings, the total volume of which is large compared to the volume of rock. Nevertheless, the minuteness of the individual openings permits only slow rates of dirainage, and these rocks have small permeabilities and specific yields. In contrast, coarse materials, such as sand, and gravel, have large well-connected openings; and even though the total volume of pore space is small relative to the volume of rock, the permeabilities and specific yields of sand and gravel commonly are large.

The areal distribution of unconsolidated deposits is shown on the geologic map (pl. 1) ; included with the map is a cross section indicating typical subsurface relationships of the deposits. The wind deposits and alluvium, which are thin and superficial, are not significant water-bearing units. They are not differentiated on the map but are included with the older deposits with which they are associated. Particle-size distribution determined in the laboratory for samples from five geologic units are included in table 3. 
TABLE 3.-Particle-size analyses of geologic units in the Ipswich River basin

\begin{tabular}{|c|c|c|c|c|c|c|c|c|}
\hline \multirow[b]{2}{*}{ Geologic unit } & \multirow{2}{*}{$\begin{array}{c}\text { Number } \\
\text { of } \\
\text { samples }\end{array}$} & \multicolumn{2}{|c|}{ Sorting coefficient } & \multirow{2}{*}{$\begin{array}{l}\text { Number } \\
\text { of } \\
\text { samples }\end{array}$} & \multicolumn{4}{|c|}{$\begin{array}{c}\text { Grain size (average percent } \\
\text { by weight) }\end{array}$} \\
\hline & & Range & Median & & Gravel & $\begin{array}{l}\text { Medium } \\
\text { to very } \\
\text { coarse } \\
\text { sand }\end{array}$ & $\begin{array}{l}\text { Very fine } \\
\text { to fine } \\
\text { sand }\end{array}$ & $\begin{array}{l}\text { Silt } \\
\text { and } \\
\text { clay }\end{array}$ \\
\hline $\begin{array}{l}\text { Wind deposits } \\
\text { Marine depostis- } \\
\text { Outwash deposits } \\
\text { Ice-contact deposits } \\
\text { Till }\end{array}$ & $\begin{array}{r}4 \\
6 \\
42 \\
30 \\
7\end{array}$ & $\begin{array}{l}1.4-1.7 \\
1.5-7.1 \\
1.1-4.3 \\
1.3-4.3 \\
1.4-7.0\end{array}$ & $\begin{aligned} \text { (1) } \\
2.8 \\
1.6 \\
2.0 \\
5.9\end{aligned}$ & $\begin{array}{r}4 \\
10 \\
64 \\
24 \\
7\end{array}$ & \begin{tabular}{r|}
0 \\
3 \\
4 \\
28 \\
14
\end{tabular} & $\begin{array}{l}16 \\
10 \\
29 \\
33 \\
19\end{array}$ & $\begin{array}{l}59 \\
13 \\
38 \\
31 \\
16\end{array}$ & $\begin{array}{r}25 \\
74 \\
29 \\
8 \\
51\end{array}$ \\
\hline
\end{tabular}

1 Medians given only for five or more samples.

TUL

\section{DISTRIBUTION AND CHARACTERISTICS}

Till overlies the bedrock surface nearly everywhere. It is exposed in nearly half the area of the Ipswich River basin, principally on hills and ridges, and is buried by younger unconsolidated deposits in the valleys and along the flanks of many hills. The till is composed of soil and rock that was transported and spread over the land surface by ice of the Wisconsin glacial advance (Flint, 1953, p. 900-901). Till commonly forms a thin sheet called ground moraine, but it also forms a few streamlined elongate hills called drumlins.

Till ranges in thickness from less than 1 foot to at least 208 feet. The greatest known thickness of till, 208 feet, was recorded in the log of a well (North Andover 61) which penetrated the drumlin known as Boston Hill.

Till is characterized by a wide range of particle size, lack of stratification, and little or no sorting. It is, for the most part, extremely dense and tough. The matrix of most till in the basin is fined grained and compact; it commonly contains more than 50 percent silt and clay (table 3 ). The compact till is massive in some places, but it has nearly horizontal closely spaced parting planes in other places. In many exposures of till the uppermost zone, ranging in thickness from a few inches to a few feet, is loose, distinctly sandy, and generally structureless. Cobbles and boulders are more numerous in the loose till than in the compact till. The relationship of the sandy till to the clayey till is not known with certainty, but it is tentatively concluded that both were deposited during one major ice advance and retreat.

\section{HYDROLOGY OF THE TILI}

Because of its poor sorting and extreme range of particle size, till has a low specific yield and permeability. These properties were determined in the laboratory for 8 undisturbed samples of till matrix which 
did not include cobbles and boulders; the coefficients of permeability and the specific yields are low, the median being 2 gallons per day per square foot (table 2). A mass of till in place however, would have a permeability lower than that of its matrix alone because the space occupied by cobbles and boulders represents a large volume of the mass through which no flow takes place.

Till is a source of small supplies of water in its outcrop area. In general, water in the till occurs under water-table conditions, although in a few places water may be confined in lenses or layers of saturated sand and gravel within the till mass. Owing to its small permeability, the till yields water slowly to wells.

Measured depths of wells in till are as much as 36 feet, but most wells are less than 20 feet deep. Seasonal water-level fluctuations are large, up to 17 feet, and many shallow wells reportedly go dry during the summer months. Deeper wells may yield sufficient water (probably on the order of a few gallons per minute) for domestic supplies the year round. No precise data are available on the yields and specific capacities of wells in till.

During late winter and early spring the upland till masses are nearly saturated, and the water table approaches or reaches the land surface. As a result, much of the precipitation on upland till areas runs off directly to streams or to land surfaces at lower elevations. Streamflow records for the Ipswich River show that nearly all shortduration peak flows involving changes in flow rate of more than 100 cfs (cubic feet per second) occur between mid-December and midApril. Much of this peak discharge must be attributed to rapid runoff from the upland till areas. During the summer and early fall months, however, most of the precipitation that falls on till areas is retained in the soil zone and is subsequently lost to the basin through evapotranspiration. Records of ground-water levels in till show that recharge largely ceases and storage is greatly depleted during the months from April to October of most years. Direct contributions from till areas to stream base flows are probably small, but ground-water discharge from till undoubtedly helps to maintain ground-water levels in the low-level ice-contact and outwash deposits that lie between most till masses and the stream channels.

\section{ICE-CONTACT DEPOSITS}

\section{DISTRIBUTION AND CHARACTERISTICS}

Ice-contact deposits are masses of material that were deposited by melt-water streams in and near a wasting ice sheet. They represent a final phase of glaciation. At places in the Ipswich River basin, icecontact deposits are partly or completely concealed by the overlap of 
adjacent marine or outwash deposits; at a few places in the coastal area, ice-contact deposits and marine deposits are interbedded, a fact suggesting that these units are in part contemporaneous and that the sea advanced across the coastal area while ice blocks were still present. Ice-contact deposits are exposed over about 19 percent of the basin.

Ice-contact deposits in the basin occur as kames, kame terraces, kame plains, kame deltas, and ice-channel fillings. Kames are knobby hills which are at places grouped to form kame fields. Kame terraces are the flat tops of materials deposited between hillsides and adjacent ice masses in the valleys. Kame plains, like kame terraces, have flat tops, but are bounded on nearly all sides by relatively steep slopes formed when the ice mass against which the materials were deposited melted. Kame deltas are flat-topped features deposited in bodies of water. Ice-channel fillings are linear or sinuous ridges with either flat or rounded tops. Many of these landforms are marked by kettles which are depressions formed by the melting of buried or partly buried ice blocks.

The maximum known thickness of ice-contact deposits, 78 feet, was reported in the $\log$ of well Middleton 119, about half a mile northwest of Burleys Corner. In the vicinity of test hole Middleton 60, about a quarter of a mile southwest of Burleys Corner, the difference in altitude between the bedrock, as determined by seismic methods, and the surface of the deposit suggests that the deposit may be as much as 160 feet thick. The thickness of each deposit is partly determined by the topography of the underlying till or bedrock surface. Thus kameterrace deposits, which are perched against valley walls, pinch out at the exposed contact with till or bedrock, generally thicken toward the center of the valley, and wedge out or thin appreciably where the icecontact slope dips toward the bottom of the valley. Some kames and kame terraces are marked by protruding knobs of bedrock, and their greatest thicknesses ordinarily occur near ice-contact slopes farthest from the bedrock exposures.

Ice-contact deposits are characterized internally by abrupt changes in stratification, grain size, and structure. Bedding deformed by collapse, faulting, or folding may be seen at some places. Where these characteristics cannot be examined, as in well cuttings, the ice-contact deposits generally cannot be identified with assurance.

The ice-contact deposits in the Ipswich River basin consist principally of sand and gravel but include small amounts of silt and clay. The composition of 24 samples of ice-contact deposits analyzed in the laboratory averaged (by weight) 28 percent gravel, 33 percent medium to very coarse sand, 31 percent very fine to fine sand, and 8 percent silt and clay (table 3). The representativeness of the laboratory results 
is at least partially confirmed by data from drillers' logs. Relative thicknesses of materials in four ranges of grain size were recorded from 439 logs of wells and test holes. The bar graphs in figure 4 give percentages of the four grain-size categories in test holes penetrating ice-contact, outwash, and marine deposits. Grain sizes described as "gravel" or "sand and gravel" predominate in the ice-contact deposits, and the remainder of the materials found were about equally divided between "sand" and "sand with some silt or clay." These data also confirm field observations which have stressed the heterogeneous nature of the ice-contact deposits.

Field observations of ice-contact deposits indicate that size-sorted materials occur in discontinuous layers. The contacts between adjacent layers generally are sharp, and abrupt changes in grain size in both horizontal and vertical directions are common. Bedding is horizontal to steeply dipping, and some deposits are crossbedded. Some deposits, particularly kame deltas and some kame plains, show deltaic structure, with foreset beds that are relatively fine grained and topset beds that are relatively course grained and poorly sorted. In

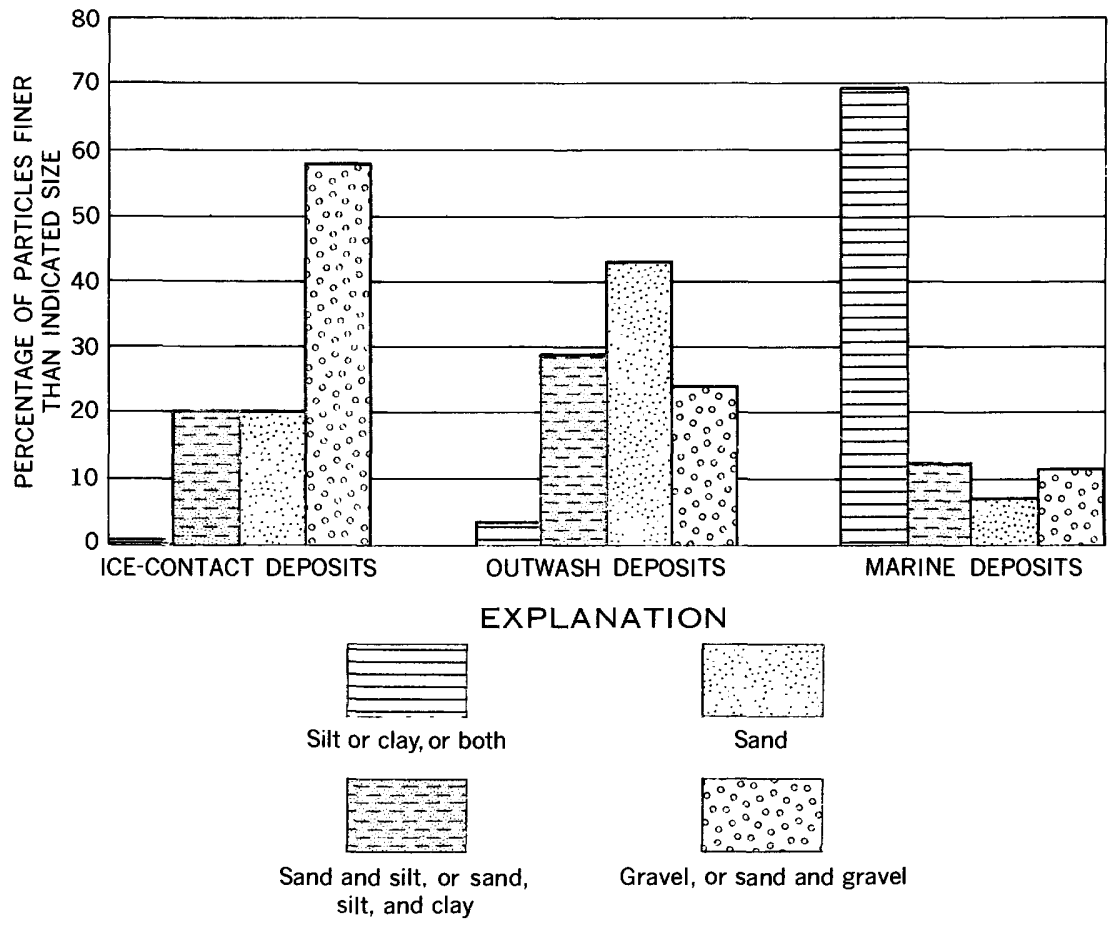

Figure 4.-Particle-size distributions reported in logs of test holes penetrating icecontact, outwash, and marine deposits. 
general, the materials are not cemented, but hard layers consisting of either fine- or course-grained materials cemented with iron oxide occur from place to place.

The individual deposits may differ markedly from one another. At one extreme, commonly in ice-channel fillings and kames, the deposits are poorly sorted and poorly stratified and consist of particles of all sizes. They may contain small bodies of till. At the other extreme, the deposits are well stratified and moderately well sorted and the range of predominant particle sizes is small. Such deposits commonly form kame terraces and kame plains. A distinctive feature of many of the kame plains and terraces is a horizontal cap of gravel. This cap usually conceals sand, which makes up the bulk of the deposits.

\section{HYDROLOGY OF THE ICE-CONTACT DEPOSITS}

The predominance of sand and gravel suggests that, in general, the specific yield and permeability of the ice-contact deposits are medium to large. However, the wide variation in the composition and sorting of the individual deposits implies a similarly wide variation in the permeabilities. The coefficients of permeability for 13 samples of icecontact deposits range from 1 to $8,900 \mathrm{gpd}$ per sq ft (gallons per day, per square foot; table 2). These values probably do not represent the full range of values of permeability to be expected from ice-contact deposits but probably include the common range of values. As expected, the finer grained ice-contact deposits, represented by five undisturbed samples from three locations, had lower coefficients of permeability (from 24 to $990 \mathrm{gpd}$ per sq $\mathrm{ft}$ ) than the coarser grained ice-contact deposits, represented by six disturbed samples from six locations, which had coefficients of permeability ranging from 400 to $8,900 \mathrm{gpd}$ per sq ft.

The ice-contact deposits yield small to large quantities of ground water to wells. The reported yields of nine large-diameter gravelpacked wells range from 215 to $730 \mathrm{gpm}$ and the yields of driven and dug wells range from $21 / 2$ to $150 \mathrm{gpm}$. The median yield for all wells in ice-contact deposits is $39 \mathrm{gpm}$.

Wells in the more permeable ice-contact deposits are expected to have comparatively large specific capacities. The specific capacities of the few wells for which yield and drawdown data were available support this expectation. In 23 wells, which were pumped for periods ranging from 1 to 181 hours, specific capacities ranged from 3 to 125 and averaged $27 \mathrm{gpm}$ per foot of drawdown. The median specific capacity, which probably is more representative than the average, was $18 \mathrm{gpm}$ per foot of drawdown.

By means of a method developed by Theis and others (1954), coefficients of transmissibility were estimated from the specific capacities 
of 15 wells for which sufficient data were available. Estimated coeffi. cients of transmissibility for 15 ice-contact aquifers range from 8,000 to $74,000 \mathrm{gpd}$ per ft. The median is $30,000 \mathrm{gpd}$ per ft. Uncertainties regarding storage coefficients and well characteristics make these estimates somewhat unreliable as measures of specific aquifers, but the range of values is probably a conservative estimate of the transmissibilities that are most common in the basin.

Depths to the water table in wells penetrating ice-contact deposits are as much as 35 feet below land surface, but the average depth is less than 10 feet. The annual range of seasonal fluctuations of water levels in ice-contact deposits is small-normally less than 5 feet. Data on depths, yields, and static water levels in wells in ice-contact deposits are summarized in figure 3.

\section{OUTWASH DEPOSITS}

\section{DISTRIBUTION AND CHARACTERISTICS}

Outwash deposits were formed by glacial meltwater streams, often contemporaneously with the ice-contact deposits. However, the outwash materials were transported into valleys and lowlands, usually beyond the terminus of the glacier. Outwash deposits underlie low terraces and swamps of about 12 percent of the Ipswich River basin. They are especially extensive along the headwater streams of the Ipswich River system in Wilmington, in Cedar Swamp in Reading, in the valleys of Fish and Pye Brooks in the north-central part of the basin, and in the area north of Wenham Lake in the southeastern part of the basin (pl. 1). Outwash deposits also occur as scattered patches in the swamps, along the margins of many swamps, and along the streams. The deposits form broad, gently sloping sand plains, such as the one in the valley of Fish Brook northeast of Topsfield, or form gently sloping terraces of small areal extent. In general, outwash deposits overlie bedrock or older unconsolidated deposits, although in the coastal area outwash and near-shore marine deposits are intimately associated and are in part contemporaneous.

The thicknesses of outwash deposits range from less than 1 foot to about 200 feet. The greatest measured thickness, 102 feet, was reported in the $\log$ of well North Reading 131, but seismic traverses described in the Wilmington-Reading report suggest that elsewhere the thickness may be at least 200 feet.

Outwash deposits consist principally of sand but include silt, clay, and some gravel. The average composition of 64 samples of outwash deposits analyzed in the laboratory is 4 percent gravel, 29 percent medium to very coarse sand, 38 percent very fine to fine sand, and 29 percent silt and clay (table 3 ). The data of figure 5 support the 
conclusion drawn from field evidence that outwash deposits are finer textured than ice-contact deposits but coarser textured than marine deposits.

\section{HYDROLOGY OF THE OUTWASH DEPOSITS}

The specific yields of 30 samples of outwash deposits collected at 22 locations in the Ipswich River basin range from 20 to 48 percent; the average is 37 percent and the median is 38 percent (table 2). These samples probably have the common range of values in the Ipswich basin.

Analysis of grain-size distributions in samples from outwash deposits suggests that the permeabilities, although generally low, may range from very low to medium. The coefficients of permeability of the 30 samples mentioned above range from 0.03 to $850 \mathrm{gpd}$ per sq $\mathrm{ft}$; the average is $188 \mathrm{gpd}$ per sq $\mathrm{ft}$, and the median is $66 \mathrm{gpd}$ per sq $\mathrm{ft}$ (table 2 ). These figures do not represent the full range of values of permeability to be expected from outwash deposits, but probably include the common range of values.

Outwash deposits store large amounts of ground water which they transmit slowly. In some places outwash deposits provide supplementary storage for adjacent or subjacent ice-contact deposits, and throughout the basin they furnish a large share of the base flow of streams. Outwash deposits are sufficiently permeable at some places to yield small to moderate quantities of water to wells.

At most places outwash deposits will probably produce enough water for domestic use, and it is possible that groups of carefully constructed and developed wells, properly dispersed in the areas of coarser grained deposits, could yield enough water for commercial or industrial use. The largest reported yield of wells penetrating outwash deposits, $700 \mathrm{gpm}$, is from a large-diameter gravel-packed well developed for municipal supply in Peabody.

Data on drawdown versus yield are available for only six wells. The specific capacities of these wells are $8,9,10,11,15$, and $33 \mathrm{gpm}$ per foot of drawndown. Estimates of aquifer transmissibilities based on the specific capacities range from 8,000 to $44,000 \mathrm{gpd}$ per $\mathrm{ft}$.

Depths to the water table in outwash deposits are similar to those measured in ice-contact deposits, the average depth being less than 10 feet below land surface. The range of seasonal fluctuations of water levels in outwash deposits is small, normally less than 5 feet. Data on depths, yields, and static water levels in outwash deposits are summarized in figure 3.

Both outwash and ice-contact deposits are known to underlie much of the area covered by swamp deposits. Together, these deposits afford maximum opportunity for recharge and recovery of ground water in 
the basin. Areas underlain by these deposits contribute least to direct surface runoff and short-duration peak streamflows. Outwash deposits discharge ground water slowly and contribute appreciably to the annual base flow of the streams, but ice-contact deposits, because of their greater permeability and their generally higher topographic positions, drain rapidly and contribute little to base flow during lowflow periods.

\section{MARINE DEPOSITS}

\section{DISTRIBUTION AND CHARACTERISTICS}

Marine deposits underlie lowlands in the coastal area and in the valleys of the Ipswich River and its tributaries for a distance of about 8 miles inland from the present coastline. They were deposited during a rise of sea level which accompanied the wastage and retreat of the last Pleistocene ico sheet. At places, the marine deposits form thin layers over till and bedrock at altitudes as much as 90 feet above present sea level. Marine deposits are exposed in about 5 percent of the Ipswich River basin.

The marine deposits commonly overlie bedrock, till, and ice-contact deposits, and are overlain at places by outwash deposits. The contact between marine deposits and underlying unconsolidated deposits commonly is sharp, although at some places material from the underlying deposits may be mixed with the marine deposits, and at places, marine deposits are interbedded with ice-contact or outwash deposits. The thickness of marine deposits ranges from less than 1 foot to as much as 77 feet as reported in the log of well Ipswich 303 .

The marine deposits consist principally of clay and silt, but they include small amounts of sand and, locally, some gravel. Ten samples of marine deposits average 39 percent clay, 35 percent silt, 13 percent very fine and fine sand, 10 percent medium to very coarse sand, and 3 percent gravel (table 3). Data from drillers' logs (fig. 4) also support the conclusion that the marine deposits are composed of predominantly fine-grained materials. At many places a well-sorted medium quartz sand overlies the clay and silt, and locally a well-washed gravel is associated with the sand. The sand and gravel strata, which probably indicate near-shore marine deposition, are as much as 40 feet thick. Near the base of the marine deposits, thin layers of clay and silt commonly alternate with relatively thick layers of sand, and at many places a sharply defined layer of gravel underlies the silty clay and sand. In at least one location, deltaic sand and gravel are interstratified with clay and silt. Inland, the upper sand and gravel strata appear to merge with low-level outwash deposits.

Where fine-grained marine deposits occur in thick strata the deposits are commonly found to have two distinct zones: an upper zone 
of light-brown to olive-brown clay and silt, and a lower zone of lightgray to blue-gray clay and silt. The upper zone is generally hard and dry, and it is characterized by closely spaced blocky fractures. Dark staining, which is probably a deposit of manganese and iron, occurs in the fissures. Both zones have nongraded laminations, although the laminations are more easily seen in the hard, dry upper zone. Both zones contain lenses and strata of fine sand, some of which are convoluted. The contact between the two zones was examined in several exposures. In these exposures the upper dry brown silty clay grades downward into saturated gray plastic silty clay of a transition zone which ranges from a few inches to 4 feet in thickness. Where roots of vegetation penetrate the transition zone or the lower zone, the material surrounding the roots most commonly resembles the material of the upper zone. It is assumed, therefore, that the clays and silts were deposited in a continuous sequence and that the upper zone is a zone of leaching and weathering.

\section{HYDROLOGY OF THE MARINE DEPOSITS}

Because of the small average grain size in the marine deposits, the specific yield is small even though the porosity is large. The porosity of 3 samples of silty clay collected in the lower Ipswich River basin ranges from 42 to 55 percent (table 2 ). The specific yield of the same samples ranges from 3 to 44 percent. These few samples undoubtedly do not represent the full range of possible values, but the samples are considered to be sufficiently representative to indicate the magnitudes to be expected generally.

Coefficients of permeability of 6 samples of marine deposits range from 0.0008 to $1,400 \mathrm{gpd}$ per sq $\mathrm{ft}$. The highest value is for an undisturbed sample of sand and very fine gravel. The sample was orianted horizontally, parallel to the bedding, and it is probable that the permeability of the deposit in a vertical direction is significantly less than the horizontal permeability. The range of permeabilities found for the six samples tested probably represents the range to be expected generally in the marine deposits.

Few of the wells in the lower Ipswich River basin obtain water from the marine deposits, and in most places the unit cannot be considered an aquifer. However, the marine deposits may yield small to moderate amounts of water in areas where the deposits contain relatively large amounts of sand and gravel. For example, several wells adjacent to the Miles River in Hamilton obtain supplies of water from strata in or associated with the marine unit.

Typically, however, the fine-grained marine deposits act as a barrier to the downward movement of water from the land surface, and at places they confine water in underlying coarse-grained deposits. At 
least three flowing wells in the coastal area-Wenham 35, Hamilton 31, and Hamilton 77-demonstrate the existence of artesian pressures in deposits underlying the marine unit. Two other wells, Ipswich 41 and 331, each driven through marine clay on the edge of a salt marsh, produce potable water from aquifers below sea level. The data from these and other wells suggest that salt water may be sealed out of some aquifers by marine deposits. Some wells in apparently similar environments, Ipswich 47 for example, produce brackish water. At these wells it is evident that the marine deposits do not form an effective confining layer. The available data on depths, yields, and water levels in wells penetrating marine deposits are summarized in figure 3.

\section{SWAMP DEPOSITS}

\section{DISTRIBUTION AND CHARACTERISTICS}

Swamp deposits, including those of both fresh- and salt-water marshes, are exposed in about 17 percent of the Ipswich River basin. They are widespread along the floors of the valleys, in tidal flats along the seacoast, and in scattered small depressions in the uplands. They commonly overlie outwash in the lowlands and till or bedrock in the uplands. Wenham Swamp, the largest fresh-water swamp in the area, occupies about 3 square miles in western Hamilton and Wenham.

The swamp deposits range in thickness from less than 1 foot to at least 55 feet. The maximum known thickness, 55 feet, is reported in the $\log$ of test boring Wilmington 252, in the valley of Martins Brook. The deposits in the uplands are commonly thinner than those in the lowlands.

The swamp deposits consist of brown peat and muck interbedded or mixed in some places with sand or silt. The peat is a spongy, fibrous mass of slightly decomposed plant remains. The muck, generally dark brown or black, is a fine-textured nonfibrous mass of greatly decomposed plant remains. The sand and silt were probably deposited during recurrent flooding of the swamps and marshes.

\section{HYDROLOGY OF THE SWAMP DEPOSITS}

Hydrologic properties were determined in the laboratory for 10 samples of swamp deposits (table 2) which were collected at five locations. Porosities range from 55 to 92 percent; specific yields range from 42 to 86 percent; and permeabilities range from 0.2 to $1,960 \mathrm{gpd}$ per sq $\mathrm{ft}$. The smallest values of permeability were obtained for samples of muck, but the smallest values of specific yield were for peat. The 10 samples for which permeability was determined were paired; each pair consisted of one sample oriented in a horizontal plane and the other sample oriented in a vertical plane. 
For muck, there was no significant difference in the horizontal and vertical permeabilities, but for peat the vertical permeability was notably smaller than the horizontal permeability. These data suggest that the swamp deposits as a unit are relatively impermeable in the vertical direction.

Swamp deposits do not yield water to wells but they may have an important influence on ground-water recharge and discharge. The low vertical permeabilities of swamp deposits suggest that these deposits retard the movement of water between the surfaces of the swamps and the more permeable outwash deposits that underlie the swamp deposits in most of the area. Field observations indicate that at some places water may at times be perched on or within the swamp deposits, or confined under artesian pressure in the materials beneath the swamp deposits. The effect of confinement at one location is illustrated by hydrographs from a pair of observation wells 10 feet apart in the Wilmington-Reading area (fig. 5). During the period of record the water level in the deeper well (Wilmington 447), which penetrated outwash deposits, remained higher than the water level in the shallower well (Wilmington 448), which penetrated only the swamp deposits overlying the outwash. The higher water levels in the deep well indicate that water in the underlying outwash deposits is under greater than hydrostatic pressure and, therefore, is confined by the overlying swamp deposits. The hydrographs also show that seasonal fluctuations of water levels in this swamp are very small and that the water table is at or near the land surface all year. Water levels measured in other swamps have shown a greater range of fluctuations than those cited here, but in general, water levels remain within a fer, feet of the swamp surfaces during most years.

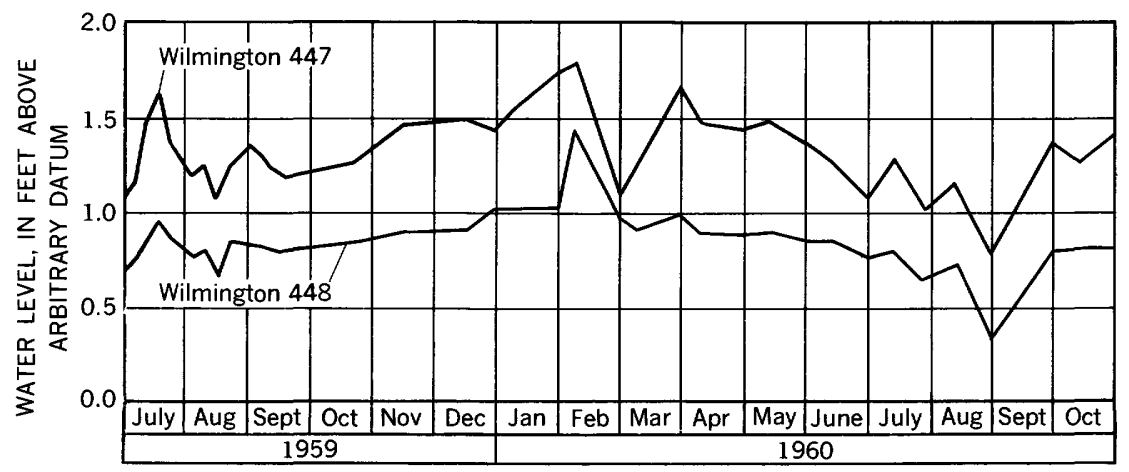

Figure 5.-Water levels in two wells 10 feet apart in a swamp off Glen Road, Wilmington. Wilmington 447 was finished in outwash deposits beneath swamp deposits. Wilmington 448 was finished in swamp deposits. 
The influence of swamp deposits on the hydrology of the basin is greater than their relative volume would indicate. The hydrologic effects of the swamp deposits are principally due to the following factors: Porosities as great as 92 percent in the deposits permit large volumes of storage; low altitudes and level topography allow maximum opportunity for retention of water; dense vegetation and free water surfaces afford maximum opportunity for evapotranspiration; the proximity of most swamp areas to stream channels, permits the ponding of streamflow during flood stages; and the slow release of ponded water reduces peak discharges and increases base runoff in the streams.

Quantitative data regarding swamp deposits are generally not available. For example, the amount of water lost to the basin each year by evapotranspiration from swamps is unknown, although it is assumed that the rate of evapotranspiration from swamp areas is considerably greater than the average rate (about 20.5 in. per yr) computed for the entire basin. The amount of water stored in swamp deposits is also unknown because of the sparseness of subsurface data in swamp areas. The amount of water ponded on swamp surfaces at a given time is a third unknown which, however, is more easily estimated than the first two. Observations indicate that early in April of most years there may be an average of 1 foot of ponded water on the fresh-water swamps. The water thus ponded amounts to about $41 / 2$ billion gallons.

Most of the water ponded on the swamps drains into stream channels during a fairly short period in the late spring. If runoff is assumed to occur over a 2-month period, 1 foot of ponded water on swamps would add about $75 \mathrm{mgd}$ (million gallons per day) to streamflow measured at the gaging station near Ipswich. If, during the subsequent 2-month period, a 1-foot thickness of swamp deposits with a specific yield of 50 percent were dewatered, and evapotranspiration accounted for an estimated two-thirds of the water, the contribution to streamflow could be an additional $12 \mathrm{mgd}$.

Recharge of ground water from swamp deposits to underlying stratified drift is undoubtedly an important function, or potential function of swamp areas. However, the magnitude of existing or potential recharge cannot now be estimated, owing to the lack of knowledge of vertical permeabilities in swamp materials-especially the permeability of the layer of silty muck that apparently lies at the base of most swamp deposits.

In summary, the swamp systems in the Ipswich River basin function as huge storage reservoirs which reduce peak storm runoff by temporarily impounding large volumes of water that otherwise 
would leave the basin quickly, and which provide large volumes of potential recharge for the aquifers. At the same time these storage areas allow the loss of large volumes of water through evapotranspiration. It is apparent, therefore, that optimum development of water resources in the Ipswich River basin will require a greater quantitative knowledge than is now available on the functions of swamps in the hydrologic system.

\section{WIND DEPOSITS}

Wind deposits of late Pleistocene and early Recent age form a thin discontinuous mantle on bedrock and glacial drift throughout the area and occur as poorly formed dunes at a few places, particularly along the seacoast. These deposits consist chiefly of fine sand and silt apparently derived from drift and deposited by the wind as the last ice sheet disappeared. They are characterized by excellent sorting (table 3), scattered ventifacts, and a lack of stratification. The average thickness of wind deposits in the Ipswich River basin is about 2 feet and the maximum thickness probably is no more than 5 feet.

Throughout most of the lower Ipswich River basin the Wind deposits lie above the water table and are not a source of ground water. However, they are sufficiently permeable to permit water to percolate freely from the surface to the underlying deposits. The wind deposits were sampled at two sites. Coefficients of permeability ranged from 220 to $250 \mathrm{gpd}$ per sq $\mathrm{ft}$ in four samples (table 2).

Wind deposits are not shown on the geologic map.

\section{ALLUVIUM}

A thin layer of alluvium occurs along the streams of the area. It rests on the older geologic units traversed by the streams, and in many places it is interbedded or mixed with swamp deposits.

The alluvium consists principally of sand and silt, but at places in some of the stream channels gravel predominates. The alluvium is generally similar in physical characteristics and water-bearing properties to the outwash. It does not form a distinct water-bearing unit and, therefore, is not differentiated on the geologic map.

\section{BEACH AND DUNE DEPOSITS}

Beach and dune sand of Recent origin have been mapped in the river basin at only two places, Little Neck and Castle Hill in Ipswich (pl. 1). Fresh water exists in these deposits as shallow lenses over the saline water from the estuary. At Castle Hill, fresh water from the beach sand was reportedly used at one time for domestic supply. The amount of water available from this source is extremely small, however, and the beach deposits are not a significant water-bearing unit in the Ipswich River basin. 


\section{HYDROLOGY}

\section{ORIGIN AND MOVEMENT OF WATER}

The source of water supply in the Ipswich River basin is the precipitation, averaging 42 inches a year, that falls within the basin boundaries. About half the precipitation is returned to the atmosphere by evapotranspiration, and the remainder leaves the basin as streamflow or is diverted from the basin by pumpage for municipal supply. The amount of runoff (including diversions) is a measure of the amount of water available for man's use.

Water that enters the basin as precipitation is disposed of in a number of ways. A small amount of water evaporates almost immediately from the land surface or from vegetation, a somewhat larger amount flows over the land surface directly into the stream channels which drain the basin, and by far the largest amount infiltrates the soil in the area on which it falls.

Water in the soil zone is available for use in plant growth, and during the growing season most water that infiltrates the soil is intercepted and transpired by vegetation. It is during the growing season, therefore, that most of the annual evapotranspiration occurs. During the remainder of the year, most of the water that enters the soil zone percolates downward through porous materials to the water table.

Ground water in the saturated zone beneath the water table is commonly thought of as being in storage, but the storage is temporary, and in the Ipswich River basin, the time of storage is relatively short. Water in the saturated zone percolates through the porous material, moving continuously in the direction of the hydraulic gradient, and is eventually discharged from the aquifer. Because hydraulic gradients are generally steep in the Ipswich River basin and geomorphic features are small, most natural ground-water discharge probably occurs in periods of time ranging from several days (in some ice-contact deposits) to several years (in large till masses).

Ground water is discharged from storage in several ways. The chief form of natural discharge is the flow of ground water to streams; this flow sustains streamflow during periods of no overland runoff. Natural discharge also occurs when water in the saturated zone reenters the unsaturated zone of soil moisture and is again available for evaporation or transpiration. In addition, natural discharge occurs at the many places in the basin where the water table intersects the land surface to form ponds, springs, and seeps. Artificial discharge occurs where ground water is pumped or flows from wells under artesian pressure or where artificial drainage channels intersect the water table. 


\section{GROUND WATER}

\section{RECHARGE}

Throughout the year only a part of the total precipitation falls on areas that allow a significant amount of recharge to the ground-water reservoir. In outcrop areas of till and bedrock the quantity of recharge per unit area is small owing to the low permeability and storage capacity of till and bedrock and to the relatively steep slopes of the land surface. The principal recharge areas in the Ipswich basin are the outcrop areas of outwash, ice-contact deposits, and possibly swamp deposits. Outwash and ice-contact deposits are sufficiently permeable to allow rapid infiltration, and at most places and times they have enough storage capacity to accept all potential recharge. Typically, these deposits underlie terraces and plains whose moderate slopes and flat tops retard runoff and afford maximum opportunity for infiltration.

The flat, poorly drained swamp surfaces afford maximum recharge potential. In addition to direct precipitation, these surfaces collect runoff from adjacent higher land and are flooded by the overflow of streams during part of the recharge season each year. In spite of their favorable topographic location, the lowland swamps are of uncertain significance as intake areas. As noted earlier, the swamp deposits have vertical permeabilities sufficiently small to impede the movement of water from the surfaces of the swamps to the underlying outwash deposits. Nevertheless, although recharge is undoubtedly retarded, even very slow leakage from the swamp deposits would contribute an appreciable volume of recharge over the 26 square miles of fresh-water swampland in the Ipswich River basin.

During most of the recharge season and the early part of the growing season (October to May), the water table is at or near the swamp surfaces. Because the underlying deposits normally are fully saturated at this time, they can store no additional water, and potential recharge is rejected. Late in the growing season many of the swamp surfaces are dry, and the outwash deposits underlying the swamp deposits may not be fully saturated. Flooding seldom occurs at this time of the year, and most precipitation is retained by the swamp deposits. Maximum recharge probably occurs as the result of precipitation and flooding at the beginning of the recharge season (October to December).

A small amount of recharge enters aquifers by infiltration from streams. In the Ipswich basin recharge of this kind probably occurs naturally only during bankfull or flood stages of the streams. At some places, however, recharge is artificially induced from streams by the withdrawal of water from nearby wells. For example, recharge 
is induced from time to time at the Reading municipal well field (Baker and others, 1964, p. 125-150). In the lower Ipswich River basin conditions similar to those at the Reading well field may exist at the site of one or more of the Danvers-Middleton municipal supply wells near the Ipswich River.

\section{DISCHARGE}

\section{NATURAL DISCHARGE}

Most ground water in the Ipswich basin is discharged by evapotranspiration or by seepage to ponds, springs, swamps and streams. Discharge of ground water by transpiration occurs where the roots of plants penetrate the water table or the capillary fringe above the water table. Evaporation of ground water occurs where the capillary fringe or the water table is at or near the land surface. Swamps are the principal areas in which ground water is discharged by both evaporation and transpiration.

The quantity of water discharged from springs is small. During the recharge period, particularly in the early spring, many small seepage springs are formed in low places, and at points of contact between bedrock and overlying unconsolidated deposits. Small fracture springs in the bedrock are especially noticeable along roadcuts during the winter.

Ground water is discharged to the Ipswich River and its tributaries throughout the year. The surfaces of the streams normally act as base levels for ground-water flow, and changes in the altitudes of stream surfaces affect the discharge of ground water. A rise in stream stage will decrease the hydraulic gradient of the ground-water flow and will thereby decrease the rate of ground-water discharge. Conversely, the lowering of a stream level will tend to increase the rate of ground-water discharge. For example, the artificial raising of stream stages by a dam, such as that on the Ipswich River above Ipswich, decreases the rate of ground-water discharge, whereas a deepening of stream channels, such as that proposed for the Wilmington-Reading area, would serve to increase ground-water discharge. At the present time, however, changes in stream stages introduced by manmade structures probably have relatively little influence on ground-water flow.

Ground-water discharge to the Ipswich River and its tributaries is the principal source of base flow in the streams. An unknown amount of water also is contributed to base flow by runoff from swamp surfaces during much of the year. However, during low-flow periods of late summer and early fall, most of the surface water has drained from the 
swamps, and streamflow is sustained almost entirely by discharge of ground water from storage.

In contrast to recharge, which takes place intermittently, discharge takes place continuously both as evapotranspiration and ground-water runoff. During the winter and early spring when the rate of groundwater evapotranspiration is low, the rate of ground-water runoff is large. Conversely, during the growing season when the rate of ground-water runoff is low, the rate of ground-water evapotranspiration is large. These opposing influences tend to balance, making the rate of ground-water discharge much more constant than the rate of surface-water runoff.

\section{ARTIFICIAL DISCHARGE}

In the Ipswich River basin most artificial discharge of ground water occurs from wells. The nature and amount of such discharge is described in the section on ground-water use. Ground water is also discharged by effluent seepage to artificial drains. Artificial drainage in the area consists mostly of ditches on farms and underdrains in housing developments; the amount of ground water discharged thereby is probably small.

\section{STORAGE}

Ground water is only one of the elements of a complex hydrologic system. The three components of the system discussed in this report-precipitation, surface water, and ground water-are entirely interdependent, and the exact relationships among these elements are often obscure. Nevertheless, the functioning of the hydrologic system produces certain effects that are easily measurable and serve as useful indicators of the state of the system. Measured changes in stream stages, for example, are an index to changes in the rate of discharge of surface water from a basin. Similarly, changes in water levels in wells provide an index to changes in ground-water storage within a basin. Seasonal and annual variations of these two indexes provide much information about changes in the total hydrologic environment.

Fluctuations in ground-water levels result from changes in the ratio of recharge to discharge within an aquifer. A rise in the groundwater level reflects a net recharge and an increase in the amount of ground water in storage; conversely, a decline in water level reflects net discharge and a decrease in the amount of ground water in storage.

Hydrographs of representative wells in the Ipswich basin (fig. 6) demonstrate that water-level fluctuations in this region are cyclic. The dominant cycle is an annual one in which the periods of high- and low-water levels recur at nearly the same times each year. It is apparent from the graph of monthly precipitation at a typical station (fig. 2) that the small cyclic fluctuation in precipitation during an 


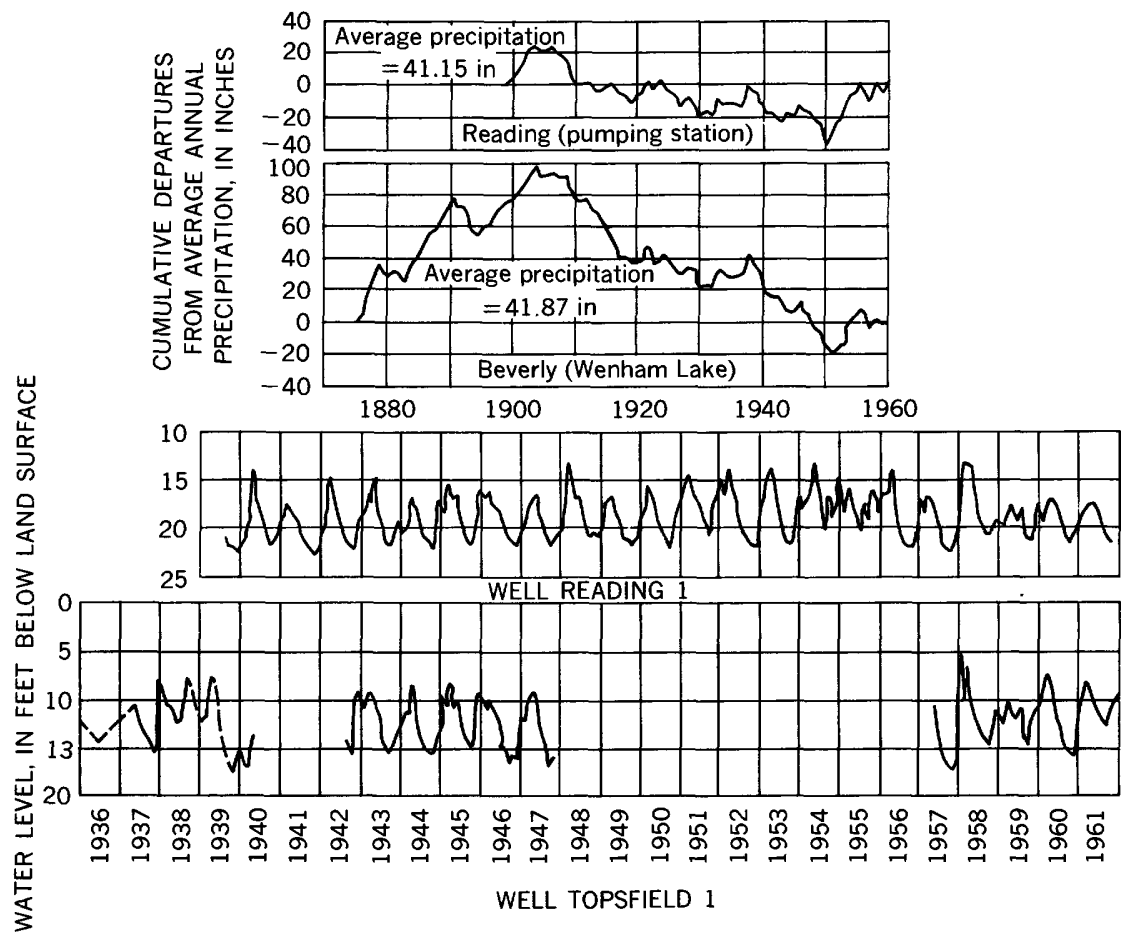

Figure 6.-Water levels in representative wells and cumulative departures from average annual precipitation.

average year cannot account for the amplitude of the annual water'level cycle. On the other hand, the water-level cycle correlates well with the annual temperature cycle and with the annual cycle of vegetation growth that corresponds to the temperature cycle.

Superimposed on the seasonal trends of the water table are fluctuations which occur in response to many local variations in the rate and amount of recharge and discharge. The manner in which the water level in a well responded to changes in recharge and discharge during the month of March 1959 is illustrated in figure 7. Although the overall trend of the water level in this well was upward during the month, the short-term fluctuations occurred as a result of the interaction of several variables, among which were temperature, the amount of precipitation as snow, and the amount of precipitation as rain. During this month, water levels were highly dependent upon temperature variations because freezing and thawing in the upper soil zone alternately held back recharge or allowed water to reach the water table from snowmelt and thawing ground. 

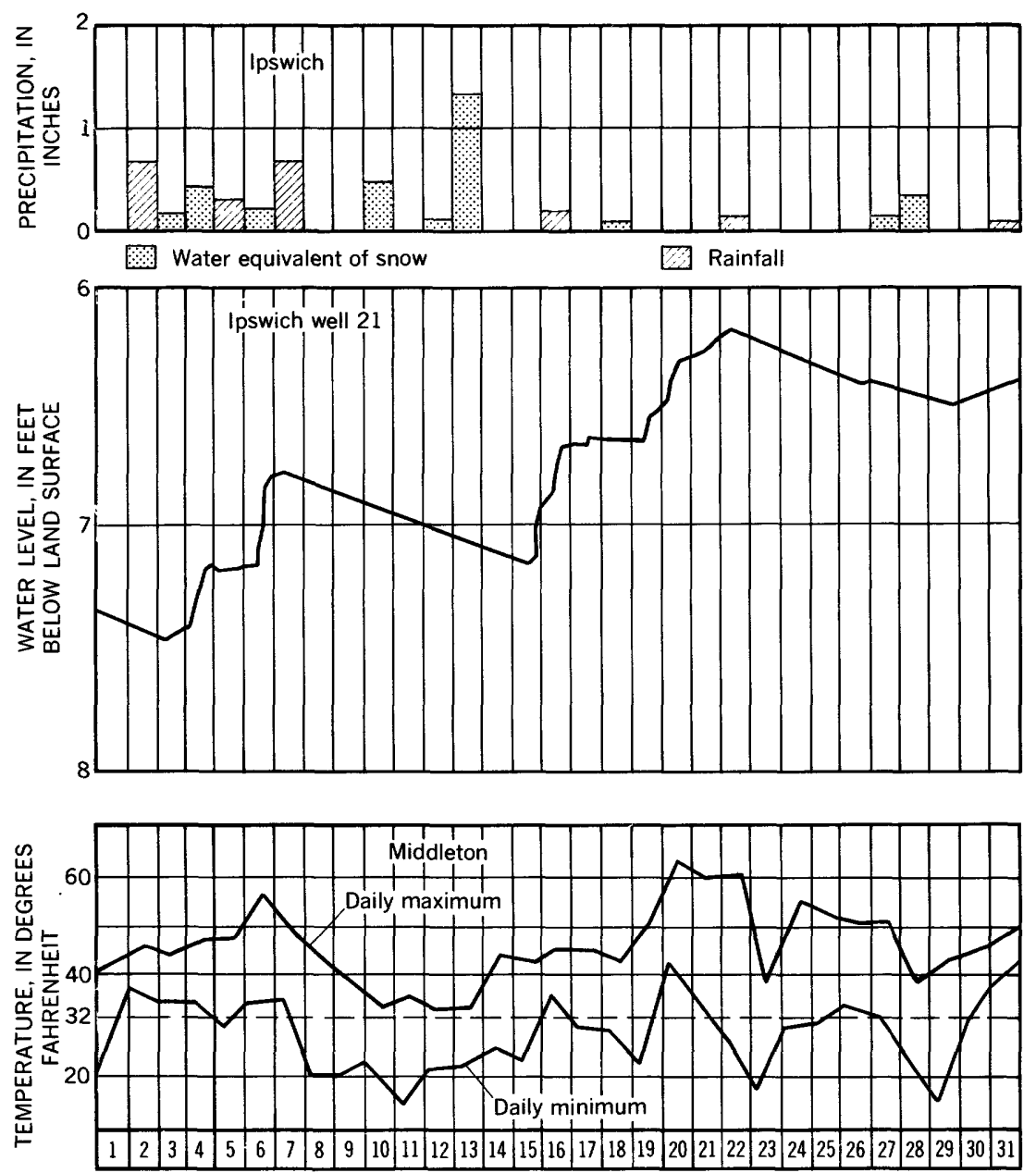

MARCH 1959

Fraure 7.-Ground-water-level fluctuations, precipitation, and temperature during a period of alternate freezing and thawing.

Water levels in several wells in the Ipswich River basin have been measured at intervals since 1939. Records of ground-water levels in nine wells-Ipswich 1 and 2, Reading 1, Topsfield 1, and Wilmington $10,29,56,58$, and 78 -have been published in water-level reports of the U.S. Geological Survey. The records are published by the U.S. Geological Survey (1939-57), beginning with Water-Supply Paper 886 and continuing annually through 1957 ; subsequent reports in this series are published at 5-year intervals. The water-level records show that, although large fluctuations occur from year to year, no long-term 
trend of water levels is perceptible during the period of record (fig. 6). However, as is shown by the cumulative-departure curves of figure 6 , long-term trends or cycles do appear in precipitation records. Annual precipitation in the basin shows a marked decline during the period 1905-50 and an upward trend beginning after 1950. The absence of a long-term downward trend in water levels indicates that the groundwater body in the Ipswich River basin is fully replenished at frequent intervals. Consequently, during parts of most years more water is available for recharge than can be retained in ground-water storage. Most of this "rejected recharge" enters streams as surface runoff and is not stored in the basin.

\section{USE}

\section{METHODS OF RECOVERY}

Ground water in the Ipswich River basin is recovered for use from wells, springs, and small ponds. Most of the ground-water supplies are pumped from wells, and a relatively few supplies, mostly for domestic use, are derived from springs. A few farm ponds, small enough to be considered ground-water rather than surface-water supplies are used for watering stock or for storage of water for emergency supply.

\section{WELLS}

Wells in the Ipswich River basin are classified according to their manner of emplacement. The major types of wells in this classification are dug, driven, and drilled wells. Descriptions of these types of wells and their methods of emplacement are available in many technical and nontechnical publications. (See, for example, Department of the Army, 1957, p. 4-194.)

Most of the wells used for domestic and public supply prior to 1900 were dug wells; comparatively few of these are still in use. The hazard of inadequate supply and the danger of contamination have resulted in the disuse of these wells except as auxiliary sources of domestic supply. Depths of dug wells in the basin range from a few feet to 37 feet, but most dug wells are less than 20 feet deep. Reported yields of $20 \mathrm{dug}$ wells range from $21 / 2$ to $70 \mathrm{gpm}$.

The use of driven wells is restricted almost entirely to areas underlain by stratified deposits. Several reasons account for this. Pipe can be driven through compact till only with extreme difficulty; the necessarily small diameter of driven wells means that the screen area through which water can enter the well is also small-prohibitively so for a well in relatively impermeable till; and finally, little storage space is available in the well itself which could make water available during a period in which the pumping rate exceeds the rate of infiltration into the well. 
Driven wells are widely used throughout the basin to provide small to medium supplies of water for domestic use, and many towns within the basin derive at least part of their municipal supply from driven wells. In a typical municipal installation, 20 or 30 such wells are pumped by means of a common suction line from a central pump. In recent years, however, the tendency has been to replace or supplement these gangs of driven wells with a gravel-packed well which may yield as much as many driven wells.

Most driven wells are between 10 and 45 feet deep. Reported yields of 145 driven wells in the Ipswich basin range from 3 to $150 \mathrm{gpm}$. The average yield is $47 \mathrm{gpm}$, and the median yield is $40 \mathrm{gpm}$.

Depths of most wells drilled into bedrock of the basin range from about 20 to 250 feet. The median depth of 112 bedrock wells is about 102 feet and the average depth is 124 feet. The maximum reported depth is 750 feet. Reported yields of 85 wells drilled into bedrock range from $1 / 2$ to $69 \mathrm{gpm}$. The median yield is $8 \mathrm{gpm}$ and the average yield is about $12 \mathrm{gpm}$.

A type of well much used for municipal water supplies is the gravelpacked well, which consists of a tubular casing and screen set into a large-diameter envelope of gravel. Reported depths of gravel-packed wells, all in stratified drift, range up to 57 feet. Reported yields of 10 large-diameter gravel-packed wells used for municipal supply range from 215 to $730 \mathrm{gpm}$.

SPRINGS

Although springs produce an extremely small part of the ground water used in the Ipswich basin, several large springs are known to provide water for domestic, farm, and commercial use. Only 3 of the 19 springs inventoried during this investigation are reported to have flows of more than $10 \mathrm{gpm}$. The largest reported yield is $150 \mathrm{gpm}$ for Pocahontas Spring, at the head of Wills Brook, Lynnfield.

The flows of most springs reportedly fluctuate little during the year, and few springs become completely dry at any time. This means that the aquifers which supply most of these springs gain sufficient recharge to replenish normal discharges. All the springs inventoried have been dug out, walled up, or otherwise improved.

\section{MUNICIPAL SUPPLY}

Nearly 95 percent of the ground water withdrawn in the Ipswich River basin is used for municipal water supply. (See pl. 2 for well locations.) During the 1960 water year an average of about $5.2 \mathrm{mgd}$ was pumped in the basin. This amount is about equal to the volume of surface water withdrawn in the Ipswich River basin in 1960. About half the ground water withdrawn for municipal use is diverted from the basin. 
Hamilton, North Reading, Topsfield, Wenham, and Wilmington depend entirely on ground water for public supply. Water used in these communities is again discharged within the basin at points of individual use (mainly cesspools and septic tanks). Thus, nearly all the water used returns to the ground and again enters the groundwater reservoir.

Danvers, Reading, and Peabody divert ground water from the basin for municipal supply. A small portion, 30,000 gpd, of the water pumped for the Danvers supply is used in Middleton and again discharged in the Ipswich River basin. Ipswich and Rowley are partly in the basin, but water for these communities is obtained outside the basin.

With the exception of one gravel-packed well in Peabody, all wells that are pumped for municipal supply in the Ipswich basin derive water from the stratified drift overlain by swamp deposits. At most well locations the stratified drift is part of the valley fill that occupies the lowland valleys of the Ipswich River and its tributaries.

The average daily withdrawal of ground water during the 1960 water year is shown in the following table:

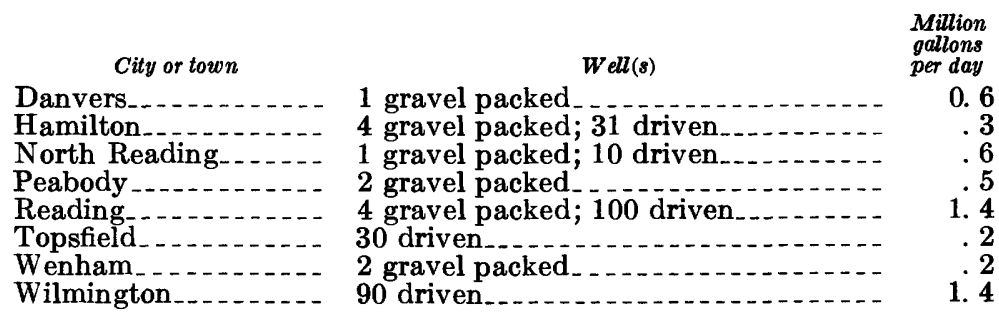

Ground water has been a source of publicly owned municipal water supply in the Ipswich River basin since 1890. The first municipally owned wells were completed for Reading in 1890, and these remained the only municipal supply until 1925 when Wilmington installed a group of wells. Since 1925 the number of communities that obtain ground water from the Ipswich basin has increased to eight, and the amount of water pumped has increased steadily. Figure 8 shows that during the 10 years from 1950 to 1960 water use in three communitiesHamilton, Topsfield, and Wenham-has increased nearly twice as fast as their population. The rate of increase is not as large as that for the entire country, but the national rate includes a large increase in industrial use, whereas the increased consumption in these towns is almost entirely from domestic use. The increased use of ground water in the lower Ipswich River basin since 1941 is illustrated by the graphs in figure 9 . 

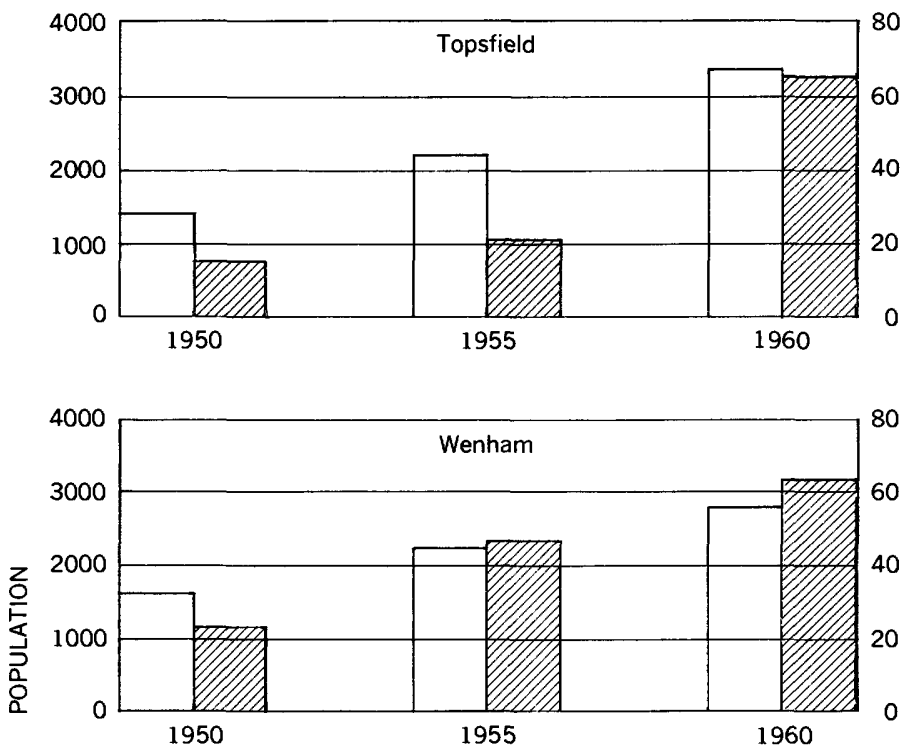

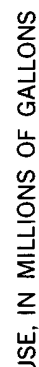

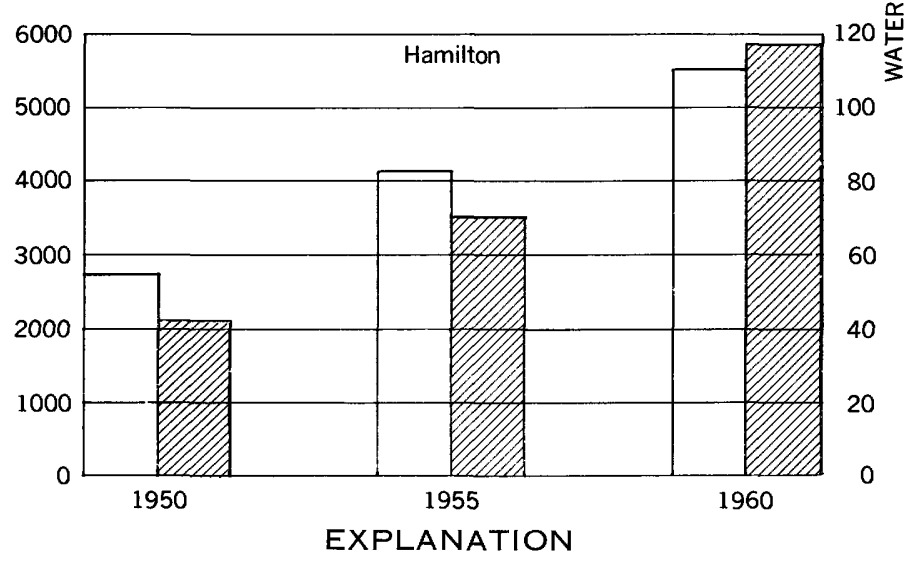

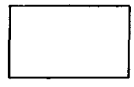

Population

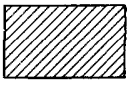

Water use

Figure 8.-Water use and population growth in three towns in the lower Ipswich River basin. 


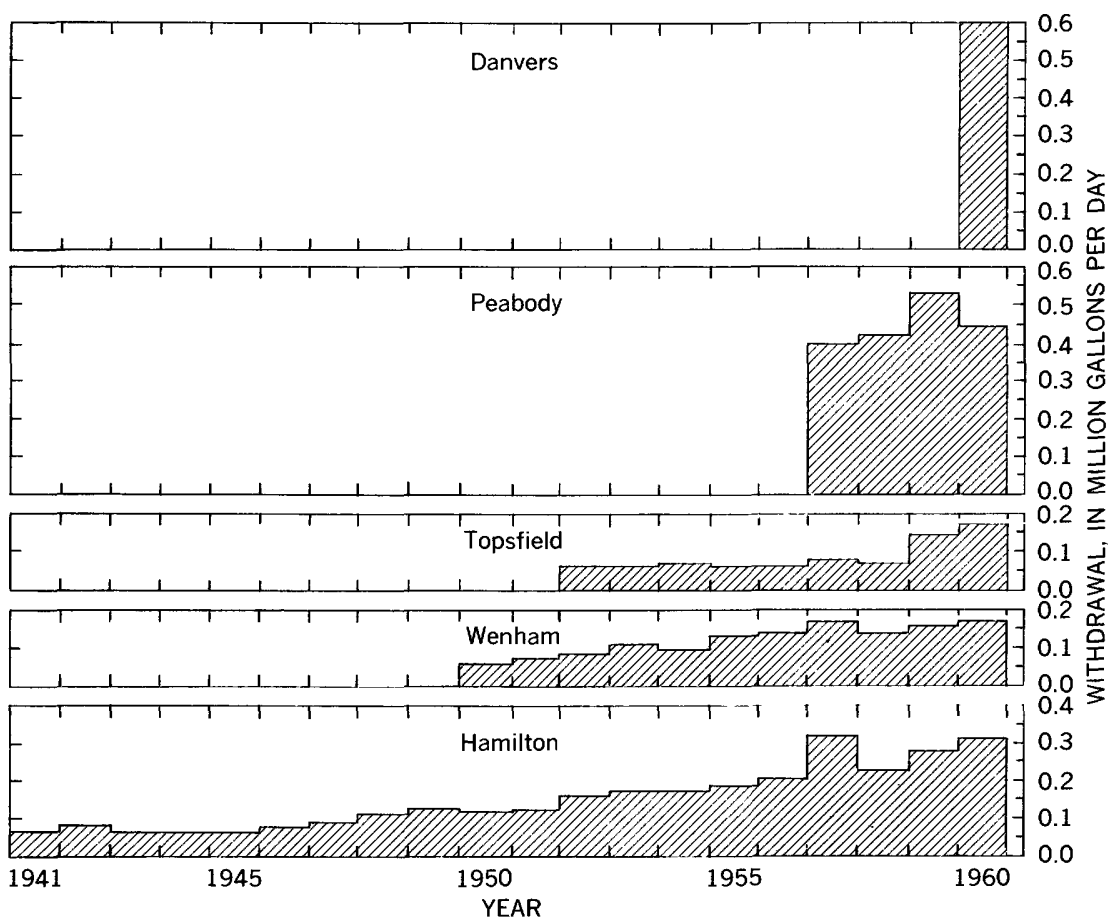

Frgure 9.-Municipal withdrawal of ground water in the lower Ipswich River basin.

\section{DOMESTIC SUPPLY}

The inventory of wells in the Ipswich River basin lists 452 privately owned wells that supply water for domestic use and for watering stock. Most wells. provide the sole water supply for a single household or farm. These 452 wells probably represented about 90 percent of the wells in use in 1960. The average daily discharge of ground water from domestic wells is estimated to be $0.17 \mathrm{mgd}$. This is 3.5 percent of the ground water used in the Ipswich River basin.

\section{DEVELOPMENT OF GROUND WATER IN THE LOWER IPSW ICH RIVER BASIN}

Information in this section relates to recharge, storage, and withdrawal of ground water in only the lower Ipswich River basin. Similar detailed descriptions of ground-water conditions in the Wilmington-Reading area are available in the report "Geology and ground-water conditions in the Wilmington-Reading area, Massachusetts" by Baker, Healy, and Hackett (1964). A summary of hydrologic conditions in the Wilmington-Reading area is included in the present report in the section "Water-Resources Development." 
To arrive at an estimate of potential ground-water use, the three following factors are considered: (1) the annual amount of effective recharge to the ground-water body, (2) the amount of natural storage available, and (3) the feasibility, from both the hydrologic and economic standpoint, of increasing the withdrawal of ground water at given locations within the basin.

\section{ANNUAL EFFECTIVE RECHARGE}

Under natural conditions much of the water that enters aquifers is subsequently lost through evapotranspiration. The water that is eventually discharged from the aquifers to streams is the part of ground-water recharge that could be intercepted by wells and withdrawn for use. This fraction of the total ground-water recharge is termed "effective recharge." Base runoff in streams ordinarily represents ground-water runoff and, by inference, effective recharge. In the lower Ipswich River basin, however, base runoff contains an unknown amount of surface-water runoff from swamps, and estimates of base runoff can be used only to set limits for effective recharge. For the period 1931-58, the least annual base runoff was about 8.3 inches (1941), the average base runoff was about 14.5 inches, and the greatest amount was 22.2 inches (1956). These values establish the upper limits of the least, average, and greatest amounts of effective recharge in the lower Ipswich River basin.

A set of lower limits for effective recharge is obtained by a method described in the Wilmington-Reading report (Baker and others, 1964). This method produces purposely low estimates by the use of two arbitrary procedures: (1) recharge is computed only for outcrop areas of ice-contact and outwash deposits, and (2) the rate of runoff for the whole basin is taken as the rate of ground-water runoff from the recharge areas.

To obtain lower limits of effective recharge for the lower Ipswich River basin, values of the least, average, and greatest annual runoffrespectively 12.6, 22, and 33.6 inches-are multiplied by a fraction (about $1 / 3$ ) which is the ratio of the area underlain by ice-contact and outwash deposits to the total area of the lower basin. The resultant figures-4.4, 7.7, and 11.7 inches-do not represent estimates of recharge; they are arbitrary figures, sufficiently conservative so that they are smaller than the amounts for the least, average, and greatest annual effective recharge during the period of record. Thus, effective recharge to ground-water bodies in the lower Ipswich River basin is assumed to fall between the lower limits just given and the upper limits represented by the figures for base runoff. 
In summary, on the basis of records for the years 1931-58, effective recharge to aquifers in the lower Ipswich basin is estimated to range as follows:

\begin{tabular}{|c|c|c|}
\hline & Inches per year & $\begin{array}{l}\text { Million gallons } \\
\text { per day }\end{array}$ \\
\hline $\begin{array}{l}\text { Least. } \\
\text { Average } \\
\text { Greatest. }\end{array}$ & $\begin{array}{r}\text { 4. } 4-8.3 \\
7.7-14.5 \\
11.7-22.2\end{array}$ & $\begin{array}{l}\text { 16. } 9-31.6 \\
\text { 29. } 3-55.2 \\
\text { 44. } 5-84.5\end{array}$ \\
\hline
\end{tabular}

Frequency curves showing recurrence of effective recharge during the period of record are shown in figure 10. The estimated range of values lies between the upper and the lower limiting curves.

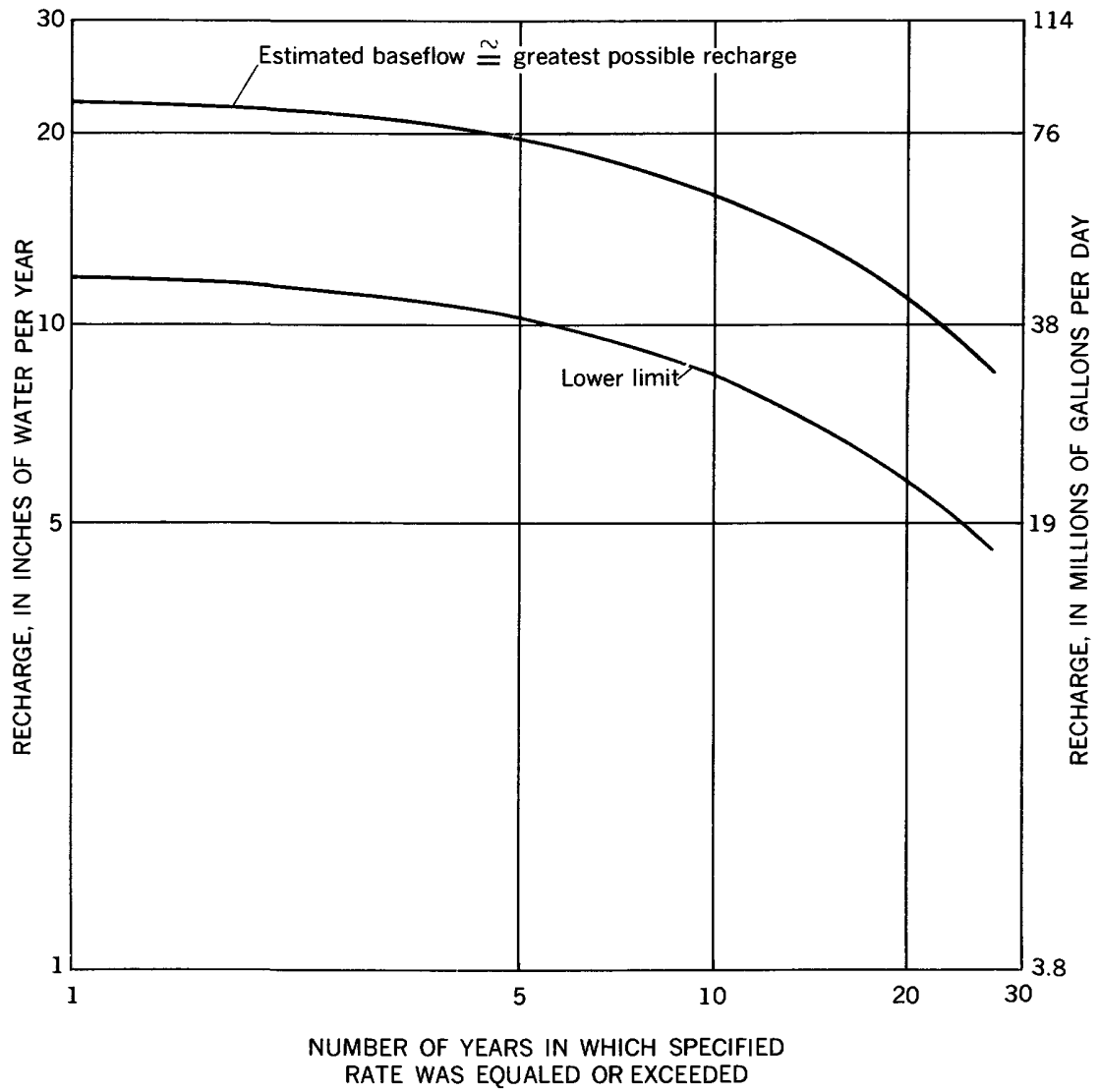

FigURE 10.-Estimated frequency of effective ground-water recharge in the lower Ipswich River basin. Actual recharge in any year of record would fall within the range bounded by the two curves. 
SUSTAINED YIELD AND STORAGE

The maximum sustained yield of an aquifer or drainage basin is greatly dependent upon the amount of storage space that is available to accept water during periods of surplus and to retain water for use during periods of deficiency. Thus, estimates of sustained yield may be based on the long-term average recharge if the volume of storage is large enough to retain water through successive years in which recharge is below average. In the lower Ipswich River basin, where nearly all usable storage is depleted and replenished annually, the maximum sustained yield is probably not much greater than the expected least annual recharge $(16.9 \mathrm{mgd})$. Use of this amount of ground water would require only a storage volume large enough to satisfy pumping demands during the summer and early fall of the driest years.

An estimate of storage has been based on the following facts and assumptions :

1. Usable storage is assumed to exist only in known stratified drift and swamp deposits.

2. The average thickness of stratified drift and overlying swamp deposits reported in logs of 190 wells and test holes in the lower basin is 30 feet. This thickness is assumed to be the average for the basin.

3. Two-thirds of the average thickness is assumed to be saturated. This estimate is based on records of water levels in 256 wells in stratified drift.

4. The average specific yield of the stratified drift is assumed to be 30 percent. This estimate is based partly on results of laboratory tests on 33 samples of stratified drift and swamp deposits from the lower basin, and partly on field estimates of hydrologic characteristics.

On the basis of these four assumptions, storage in aquifers of the lower Ipswich River basin is estimated to be 52 billion gallons. This amount could be withdrawn during 1 year at a rate of $135 \mathrm{mgd}$.

To utilize the entire volume of storage in the lower basin, an impractically large number of wells would be needed to tap the many small isolated aquifers. However, a large increase in use could result from the exploitation of a comparatively small volume of storage. For example, if the estimated sustained yield of about $17 \mathrm{mgd}$ were to be withdrawn from the lower basin, water would have to be withdrawn from storage at this rate during the period of about 150 days each year in which most potential recharge is intercepted by evapotranspiration. Such a withdrawal from storage (2.55 billion gals.) would result in an average lowering of the water table of only 1 foot in the areas of 
stratified drift, if we assume a specific yield of 30 percent. On the basis of the above calculations, the estimated sustained yield of $17 \mathrm{mgd}$ appears reasonable. Thus, withdrawals of ground water could be made in the lower basin at a rate eight or nine times greater than the 1960 rate of about $1.8 \mathrm{mgd}$.

Although total withdrawal in the basin could be greatly increased safely, expanded withdrawals at any specific site should be planned with adequate consideration for local hydrologic conditions.

\section{FEASIBILITY OF INCREASING WITHDRAWAL}

Ground water may be recovered from wells almost anywhere in the lower Ipswich River basin, although continuous use of ground water at any location is limited by the extent to which recharge to the aquifer and storage volume within the aquifer combine to sustain the yield. A still more basic limitation is placed on ground-water development by the permeability of the aquifer. For example, in a large aquifer of low permeability many closely spaced wells would be required in order to use the full recharge and storage potential. On the other hand, a single well might effectively utilize the potential of a highly permeable aquifer in which flow to the well could take place freely. The problem of ground-water development in the lower Ipswich River basin is essentially one of locating materials which have large permeabilities and which have, in addition, either a large volume of storage or are at a location which insures these materials of direct recharge from streams, lakes, or swamps.

In general, the most promising areas for further exploration are (1) those adjacent to the channels of the Ipswich River and its major tributaries, and (2) those areas where relatively permeable ice-contact deposits border, and presumably underlie, extensive swamp deposits or lakes. Several outwash plains and unusually extensive ice-contact deposits appear to possess storage volume large enough to sustain greatly increased withdrawals; the critical problem with these deposits apparently would be to locate areas of high permeability in which to place wells.

In the following description, the lower Ipswich River basin is divided into three areas, of relatively uniform hydrologic conditions. Favorable sites in each of these areas of the basin are shown on the map in plate2.

\section{WESTERN AREA}

The western area comprises parts of North Andover, Boxford, and Middleton. In this area, which is characterized by a patchwork of small isolated stratified deposits and many areas of bedrock exposures, the stratified materials are generally thin and of small areal extent. 'The volume of storage in nearly all deposits except the till masses are 
comparatively small, and the stratified deposits are predominantly fine grained. Over much of the area, therefore, conditions are unfavorable for developing large supplies of ground water. The most favorable conditions appear to exist in several stream valleys where the thicknesses of saturated deposits are relatively great and where recharge from the streams could be expected.

Test holes and wells in the valleys of Mosquito, Fish, and Boston Brooks show that the thickness of saturated stratified drift is generally above average and in several places is greater than 50 feet. Opportunity for recharge from both streams and swamps appears to be good along each of these stream valleys. However, logs of test holes show that at many sites the stratified drift is predominantly fine grained. Further exploration would be required to locate materials that are sufficiently permeable to yield water freely to wells and to permit significant amounts of recharge to be transmitted from the streams.

Several of the ponds in this area are adjacent to and presumably hydraulically connected with deposits of stratified drift (fig. 3). Areas adjacent to these ponds, therefore, offer additional possibilities for the development of ground water, although at many sites locating permeable materials would be difficult.

Most swamp deposits in the western area conceal underlying deposits of stratified drift. Although the nature and extent of most of the underlying deposits are unknown, it is safe to assume that at least some of the swamp areas would prove to be favorable for the development of ground-water supplies. A site which may warrant further exploration is an extensive swamp area of North Andover bordered by Boxford, Forest, and Lacy Streets. The ice-contact and outwash deposits exposed in and around this swamp indicates that the area is a potential source of moderate to large supplies of ground water. Exploration of this and similar areas would be required to determine whether or not thicknesses and permeabilities of the drift are great enough to support large withdrawals.

\section{CENTRAL AREA}

The central area includes Topsfield and parts of Boxford, Danvers, Hamilton, Ipswich, Middleton, Peabody, and Wenham. The area is characterized by relatively broad lowland valleys which are underlain by stratified drift. The Ipswich River and several of its major tributaries traverse these valleys in the southern part of the central area. Stratified drift underlies a significantly greater percentage of the central section than it does the western area.

The geology of much of the north-central area appears in some respects to be favorable for ground-water development. Boxford, Topsfield, and western Ipswich contain broad areas which have been mapped principally as outwash and which undoubtedly store large 
quantities of water. However, logs of wells and test holes in this area indicates that the stratified drift is relatively thin and that permeabilities are probably not high. Nevertheless, further exploration of the region is warranted, especially in the vicinity of ice-contact deposits, most of which are presumably more permeable than the outwash.

The most promising locations for further ground-water development in the central area of the lower Ipswich River basin are in the broad and generally swampy valleys adjacent to the Ipswich River and several of its major tributaries. Many sites have already been explored, and the municipal-water supplies of Danvers, Hamilton, Middleton, Topsfield, and Wenham are drawn largely or entirely from wells in these lowlands.

The thicknesses of saturated unconsolidated materials are known to be greater than 60 feet at many places along the channel of the Ipswich River and in many of the swamps bordering the river. The most extensive deposits are predominantly fine grained, but the many successful wells in this area indicate that the low to moderate permeabilities of the materials are adequately compensated for by ample recharge from streams and swamps near the wells. Additional large ground-water supplies might be obtained at any one of many sites along the Ipswich River and in its extensive swamp systems. Sites on or adjacent to the many ice-contact deposits that border or lie partly buried in the swamps are especially favorable locations. Of particular interest is the area, occupied largely by Wenham Swamp, between the Ipswich River and Wenham Lake. Although parts of this area near Pleasant Pond and the eastern border of Wenham Swamp have been explored, further exploration of the many ice-contact deposits is warranted.

\section{EASTERN AREA}

The eastern area includes parts of Beverly, Hamilton, Ipswich, and Wenham. In this area the effects of the postulated marine inundation in late Pleistocene time appear most clearly, and the topography is dominated by the rounded tops of glacial features that protrude through the relatively level surfaces of low-lying marine and outwash deposits. Extensive deposits of marine clay, silt, and sand, as well as swamp materials, conceal much of the older, more permeable stratified drift, and add to the difficulty of evaluating the ground-water potential of this section of the basin.

A number of the largest ice-contact deposits, most of them in Ipswich and Hamilton, lie above the stream valleys on till and bedrock slopes. These deposits are generally too well drained to warrant consideration as aquifers. However, other ice-contact deposits of at least moderate permeability probably exist in the stream valleys and be- 
neath the swamps of the eastern area. Such deposits, if located, should prove to be favorable sites for ground-water development.

Probably the largest number of favorable sites in the eastern area occur in the Miles River valley. Information collected for this report indicates that thicknesses of the saturated underlying drift are well above average in much of this valley. Permeabilities are generally not high even though at places coarse-grained materials of moderate to large permeability underlie finer grained materials.

Additional parts of the eastern area which appear to be favorable for ground-water development lie mostly in southern Hamilton and Wenham and in northern Beverly. Deposits near Longham Reservoir and Norwood and Beaver Ponds show promise as aquifers, although saturated thicknesses, and therefore storage volumes, appear to be small. Similar thin deposits of coarse-grained materials exist in the Chebacco Lake-Beck Pond area of Hamilton, just outside the boundary of the drainage basin, although near Beck Pond a test boring penetrated 75 feet of predominantly fine-grained material. Some of the area traversed by Black Brook in Hamilton is underlain by relatively coarse-grained ice-contact deposits, and therefore is an area of potential development.

The northeastern part of the drainage basin, almost entirely in Ipswich, apparently offers fow favorable sites. The best opportunities for ground-water development probably exist along the Ipswich River channel, southwest of the town center, although favorable conditions are not precluded elsewhere in the area, especially in the vicinity of several unexplored ice-contact deposits. In general, however, the marine sediments which partly fill the valleys in the eastern part of Ipswich and the northern part of Hamilton are predominantly fine grained, and although saturated thicknesses of these deposits may be large, permeabilities are too small to permit the economical withdrawal of large quantities of ground water.

\section{STREAMFLOW}

\section{GENERAL CHARACTERISTICS}

Streamflow in the Ipswich River normally varies in an annual cycle in which discharge gradually declines from peak flows in the early spring, reaches minimums in the late summer and early fall, and then rises and remains at moderate heights during the winter. Annual peak discharges measured at the gaging station in Ipswich (pl. 2) from 1931 to 1958 averaged about $970 \mathrm{cfs}$ and did not exceed 2,610 cfs. Annual peaks at the South Middleton gaging station averaged about $435 \mathrm{cfs}$ and did not exceed $808 \mathrm{cfs}$. Near peak flows can occur at both stations for as long as a week, when they are sustained by runoff from the large storage areas within the basin. 
The minimum instantaneous flows at the South Middleton gaging station are strongly affected by diversions, and the durations of low flows at this station are extremely variable. Flows at or near the minimums may last a few days or less than an hour. At the gaging station near Ipswich, however, low flows are nearly constant and near minimum flows may be maintained for many days. The minimum flow recorded at South Middleton is $0.1 \mathrm{cfs}$, and the minimum at Ipswich is $1 \mathrm{cfs}$; both occurred in the fall of 1957 .

Large departures from the normal seasonal pattern of streamflow are frequent, mainly as the result of abnormally high precipitation from rainstorms in winter or from tropical storms or hurricanes in the summer and early fall. Variations from normal flow patterns also result from changes in municipal pumpage. Effects of such changes are especially pronounced during the months of low flow in late summer and early fall.

Average annual runoff at Ipswich is 21.98 inches ( $86 \mathrm{mgd}$ ), and at South Middleton it is 22.41 inches (44 mgd). (See table 4.) Departures from the average runoff have ranged from about 40 percent below to about 60 percent above average at both gaging stations. Variations in diversions account for only about 10 percent of these variations in annual streamflow, and therefore changes in the annual streamflow are largely the result of varying precipitation. During the years 1931-58 annual precipitation ranged from 30 percent below average to 44 percent above average. However, because of changes in ground-water recharge and storage, an increase in precipitation during 1 year does not always produce a corresponding increase in runoff for the year. In fact, the data in table 4 show that in several years of record at the Ipswich gage annual increases in precipitation were accompanied by decreases in runoff, or vice versa.

Precipitation records obtained at seven weather stations in and near the Ipswich River basin show that average annual precipitation differs at most by about 10 percent between stations. The northern part of the basin receives slightly more precipitation than the southern part, and the eastern part of the basin, close to the ocean, may receive about 1 inch more precipitation than the inland sections. However, the larger amount of precipitation in the lower basin does not produce a corresponding increase in runoff. The average annual rate of runoff computed for the station at Ipswich is about 2 percent less than the rate computed for the upstream gage at South Middleton. This difference may indicate a greater rate of evapotranspiration in the lower basin than in the upper. This greater rate may be due to the extent of water surfaces of the large continuous swamps in the lower basin. (See section on "Water loss.") 
TABLE 4.-Annual precipitation, runoff, and base runoff, in inches, in the Ipswich River basin

\begin{tabular}{|c|c|c|c|c|c|c|c|c|}
\hline \multirow[b]{2}{*}{ Water year } & \multicolumn{4}{|c|}{ Ipswich River at South Middleton } & \multicolumn{4}{|c|}{ Ipswich River near Ipswich } \\
\hline & $\begin{array}{l}\text { Average } \\
\text { precipi- } \\
\text { tation }\end{array}$ & Runoff 1 & $\begin{array}{l}\text { Water } \\
\text { loss }\end{array}$ & $\begin{array}{c}\text { Esti- } \\
\text { mated } \\
\text { base } \\
\text { runoff } 2\end{array}$ & $\begin{array}{c}\text { Average } \\
\text { precipi- } \\
\text { tation }\end{array}$ & Runoff 3 & $\begin{array}{c}\text { Water } \\
\text { loss }\end{array}$ & $\begin{array}{c}\text { Esti- } \\
\text { mated } \\
\text { base } \\
\text { runoff } 2\end{array}$ \\
\hline $\begin{array}{l}1931 \\
1932 \\
1933 \\
19345 \\
1936 \\
1937 \\
1938\end{array}$ & $\begin{array}{l}43.75 \\
36.63 \\
52.48 \\
38.05 \\
38.99 \\
41.64 \\
39.79 \\
57.81 \\
32.71 \\
36.56 \\
29.59 \\
38.81 \\
37.38 \\
41.41 \\
40.20 \\
47.70 \\
33.79 \\
38.07 \\
37.95 \\
30.21 \\
43.67 \\
49.73 \\
41.40 \\
59.71 \\
43.48 \\
43.49 \\
31.25 \\
56.19\end{array}$ & $\begin{array}{l}421.50 \\
415.00 \\
432.20 \\
422.90 \\
423.90 \\
422.60 \\
420.55 \\
32.05 \\
24.71 \\
19.44 \\
13.00 \\
16.19 \\
20.35 \\
15.67 \\
24.51 \\
27.14 \\
16.49 \\
22.20 \\
13.47 \\
14.10 \\
20.77 \\
28.77 \\
23.94 \\
30.09 \\
26.59 \\
35.28 \\
14.03 \\
29.90\end{array}$ & $\begin{array}{r}22.25 \\
21.63 \\
20.28 \\
15.15 \\
15.09 \\
19.04 \\
19.24 \\
25.76 \\
8.00 \\
17.12 \\
16.59 \\
22.62 \\
17.03 \\
25.74 \\
15.69 \\
20.56 \\
17.30 \\
15.87 \\
24.48 \\
16.11 \\
22.90 \\
20.96 \\
17.46 \\
29.62 \\
16.89 \\
8.21 \\
17.22 \\
26.29\end{array}$ & $\begin{array}{r}11.82 \\
8.25 \\
17.70 \\
12.60 \\
13.15 \\
12.42 \\
11.30 \\
17.65 \\
13.59 \\
10.69 \\
7.15 \\
8.90 \\
11.19 \\
8.62 \\
13.48 \\
14.93 \\
9.07 \\
12.21 \\
7.41 \\
7.76 \\
11.42 \\
15.82 \\
13.17 \\
16.55 \\
14.62 \\
19.40 \\
7.72 \\
16.44\end{array}$ & 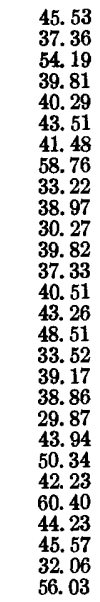 & $\begin{array}{l}21.04 \\
14.54 \\
32.03 \\
22.52 \\
23.51 \\
22.23 \\
20.17 \\
31.98 \\
23.79 \\
18.94 \\
12.58 \\
16.60 \\
19.24 \\
14.31 \\
24.31 \\
26.78 \\
15.63 \\
22.00 \\
13.48 \\
13.99 \\
20.80 \\
28.93 \\
23.83 \\
28.66 \\
25.28 \\
33.56 \\
15.04 \\
29.45\end{array}$ & $\begin{array}{r}24.49 \\
22.82 \\
22.16 \\
17.29 \\
16.78 \\
21.28 \\
21.31 \\
26.77 \\
9.43 \\
20.03 \\
17.69 \\
23.22 \\
18.09 \\
26.20 \\
18.95 \\
21.73 \\
17.89 \\
17.17 \\
25.38 \\
15.88 \\
23.14 \\
21.41 \\
18.40 \\
31.74 \\
18.95 \\
12.01 \\
17.02 \\
26.58\end{array}$ & $\begin{array}{r}13.89 \\
9.60 \\
21.14 \\
14.86 \\
15.52 \\
14.67 \\
13.31 \\
21.11 \\
15.70 \\
12.50 \\
8.30 \\
10.96 \\
12.70 \\
9.44 \\
16.04 \\
17.67 \\
10.32 \\
14.52 \\
8.90 \\
9.23 \\
13.73 \\
19.09 \\
15.73 \\
18.92 \\
16.68 \\
22.15 \\
9.93 \\
19.44\end{array}$ \\
\hline Average. & 41.52 & 22.41 & 19.11 & 12.32 & 42.47 & 21.98 & 20.49 & 14. 50 \\
\hline
\end{tabular}

${ }_{1}$ Adjusted for diversions for municipal supplies of Reading, Lynn, and Peabody.

2 Includes adjustment for diversion of ground water withdrawn by water-supply system of Reading.

3 Adjusted for diversions for municipal supplies of Reading, Lynn, Peabody, Danvers, Salem, and Beverly.

4 Estimates based on comparison of runoff at South Middleton with runoff at Ipswich.

5 Year $(1$ of $10 \mathrm{yr}$ ) used to compute runoff-base runoff relationship.

The delayed runoff is released with equal smoothness from storage in outwash and swamp deposits in all parts of the basin, as shown on discharge hydrographs at the two gaging stations. However, if the magnitudes of discharge, based on discharge per square mile, are compared, durations of flows in the low discharge ranges are appreciably smaller at South Middleton than at Ipswich. This difference is probably due to the large diversions from the Wilmington-Reading area during low-flow periods rather than to differences in topography or geology between upstream and downstream parts of the basin. (See section on "Duration of flow.")

\section{DURATION OF FLOW}

The shapes of flow-duration curves for a stream offer a means of estimating some of the hydrologic characteristics of a basin, provided the stream is unregulated, or substantially so. A steeply sloping curve indicates that streamflow is intense after a period of rainfall or snowmelt but is quickly depleted, where as curve of smaller slope indicates 
that initial streamflow is less intense and flow is more evenly sustained. Under conditions of natural runoff, therefore, a duration curve of low slope implies that the volume of available surface- and ground-water storage within the basin is large and that a significant portion of potential streamflow is retained for some time in natural storage before being released to the channel. In the Ipswich River basin, deposits of outwash and swamp materials provide large volumes for groundwater storage adjacent to the stream channels. The amount of storage volume varies from place to place, and the characteristics of the duration curves obtained at several stations afford a means of comparing storage characteristics in the basin above each station.

Flow-duration data are used also to predict the percentage of time specified flows will be equalled or exceeded in the future. The reliability of predictions depends on how accurately the data represent the natural-flow characteristics of the basin and on the amount of changes in hydrologic conditions that occur thereafter. Inevitable changes due to urban development, diversion of water, and regulation of streamflow make the prediction of future flows in the Ipswich River somewhat uncertain.

Duration curves representing flow at the Ipswich and South Middleton gages are computed on a unit area basis (cubic feet per second per square mile) in order to provide a means of comparing the two sets of data (fig. 11). For example, discharge equals or exceeds $1.82 \mathrm{cfsm}$ at both stations about 30 percent of the time, and the curves for higher discharges are nearly identical at the two stations. For discharges smaller than about $1.8 \mathrm{cfsm}$, the duration curves are divergent; for example, at the 70 percent level, discharge at South Middleton is 0.22 cfsm while at Ipswich the discharge is $0.33 \mathrm{cfsm}$. The difference in low-flow durations is due to the amount of diversion above the South Middleton gage during low-flow periods as compared with diversions from the lower basin. Most of the diversions above the Middleton gage during low-flow periods are the result of pumpage of ground water at the Reading muncipal well field. The decrease in streamflow caused by this pumpage illustrates the close relationship between groundwater and surface-water resources of the basin.

Characteristics of high flows are greatly dependent on basin topography, and the similarity of the duration curves for flows greater than $1.8 \mathrm{cfsm}$ implies a high degree of similarity in the topography of the two parts of the basin. The moderate slopes of the two duration curves indicate that large volumes of storage exist in both drainage areas. 


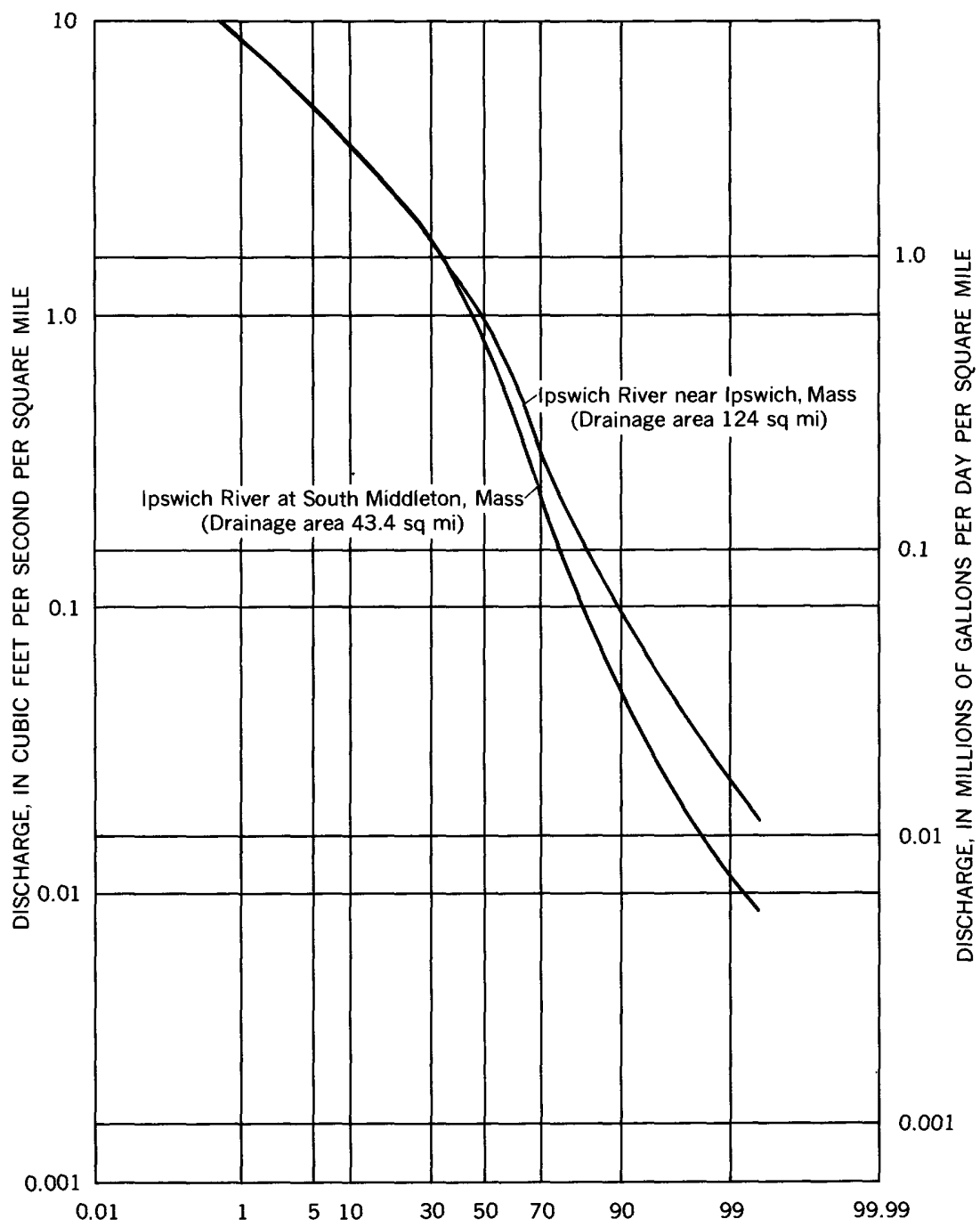

PERCENTAGE OF TIME DISCHARGE EQUALED OR EXCEEDED THAT SHOWN

Figure 11.-Cumulative duration of flows at the South Middleton and Ipswich gaging stations.

Duration curves were derived for six partial-record stations located in basins from which there were no known diversions (fig. 12). Differences among these curves reflect differences in basin characteristics. A comparison of the curves for Lubber and Martins Brooks in figure $12 \mathrm{~A}$, for example, shows that the discharge of Martins Brook is greater than that of Lubber Brook at the 70 and 80 percentile levels, 


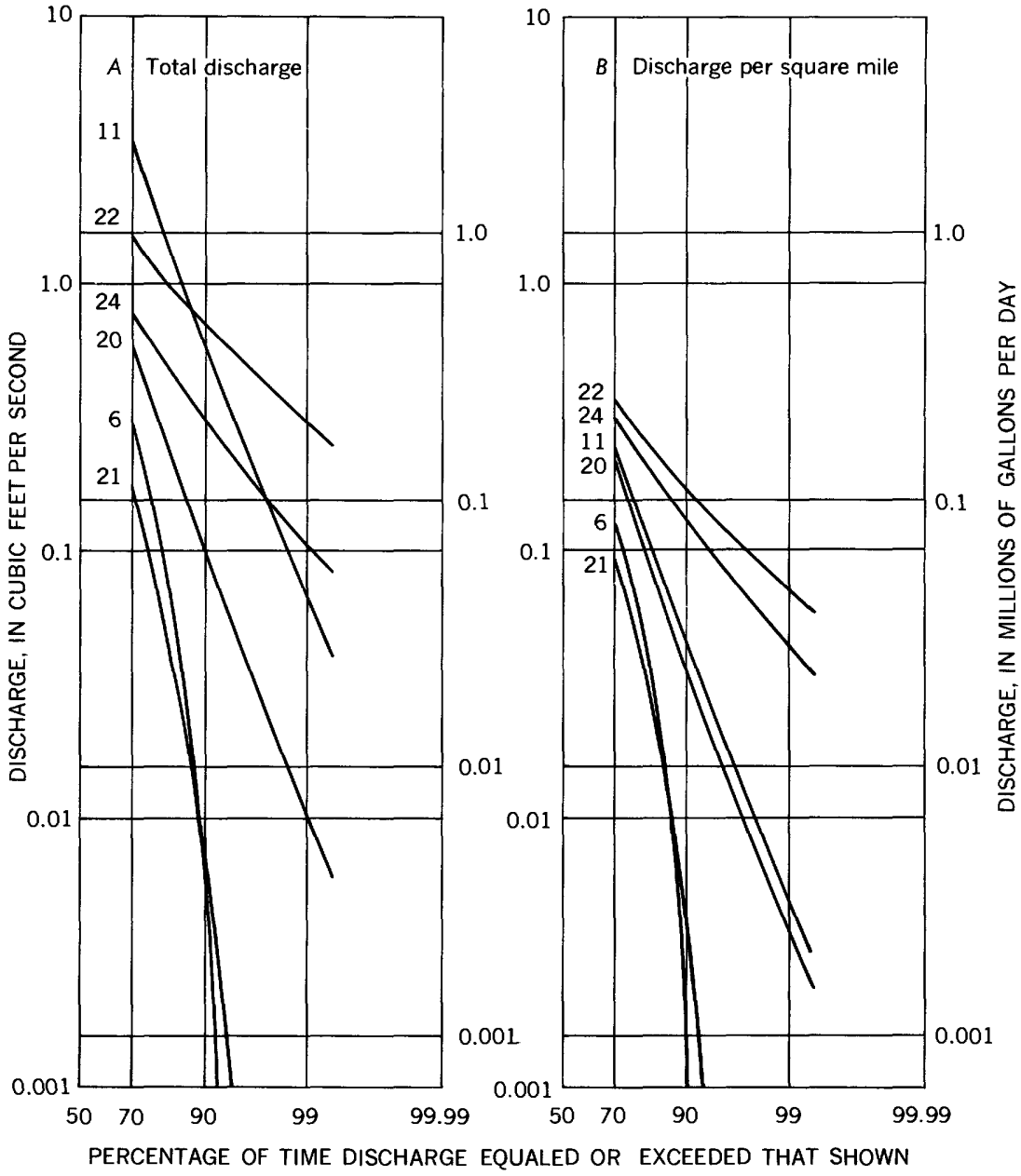

Frgure 12.-Cumulative duration of flows at partial-record stations in the Station Ipswich River basin:

6, Unnamed tributary draining Eisenhoures Pond, North Reading.

11, Martins Brook at Park St., North Reading.

20, Ipswich River at Church St., Wilmington.

21, Ipswich River at Main St., Wilmington.

22, Lubber Brook at Middlesex Ave., Wilmington.

24, Lubber Brook at Main St., Wilmington. 
but the depletion rate in Martins Brook is high and at the 90 percentile level the discharge is below that of Lubber Brook. Furthermore, the duration curve of discharge per unit area (fig. 12B) shows that base flow in Lubber Brook is greater than that in Martins Brook. These facts suggest that the volume of outwash deposits and, therefore, the volume of ground water storage is larger in the Lubber Brook basin. This conclusion has been substantiated by the geologic mapping (pl. 1).

\section{LOW-FLOW FREQUENCY}

Low-flow frequency curves graphically represent the average interval of time between occurrences of specified discharges. The curves thus provide a useful supplement to the flow-duration curves which represent the percentage of time during which specified discharges actually flowed.

Frequency curves may be used to forecast the future occurrence of discharge if hydrologic conditions during the base period are representative of long-term conditions. The use of low-flow frequency curves can therefore be of great value in assessing future storage requirements, selecting sites for water supplies, appraising the adequacy of natural flow for the dilution of wastes, and delineating general hydrologic characteristics. of the river basin. Users of the frequency curves presented in this report must bear in mind, however, that these curves represent flows that are affected both by diversions and by the use of water within the basin, and they must assume that future changes in the pattern and amount of diversions will alter the low-flow characteristics of the river.

On the basis of the data show in figure 15, and considering that diversions and hydrologic conditions during the period 1930-58 were typical, the average discharge at South Middleton during the lowest 7 days of a climatic year will be about $0.3 \mathrm{cfs}$ at a recurrence interval of 10 years. At Ipswich the lowest 7-day flow will average about 1.8 cfs about once in 10 years (fig. 16). This is not to say that these flows will occur once in every 10 years, but rather that the average interval between such occurrences will be 10 years. The useful implication follows that there is a probability of 10 percent that these discharges will occur at the respective stations in any given year; thus a 5-year recurrence interval indicates a 20 percent probability for the specified flow in any given year, and so on.

A comparison of figures 13 and 14 shows that the frequency curves derived for the station at South Middleton are somewhat steeper than those for the station at Ipswich. This difference is probably a further result of diversions above the station at South Middleton during lowflow periods. (See section on "Duration of flow.") 


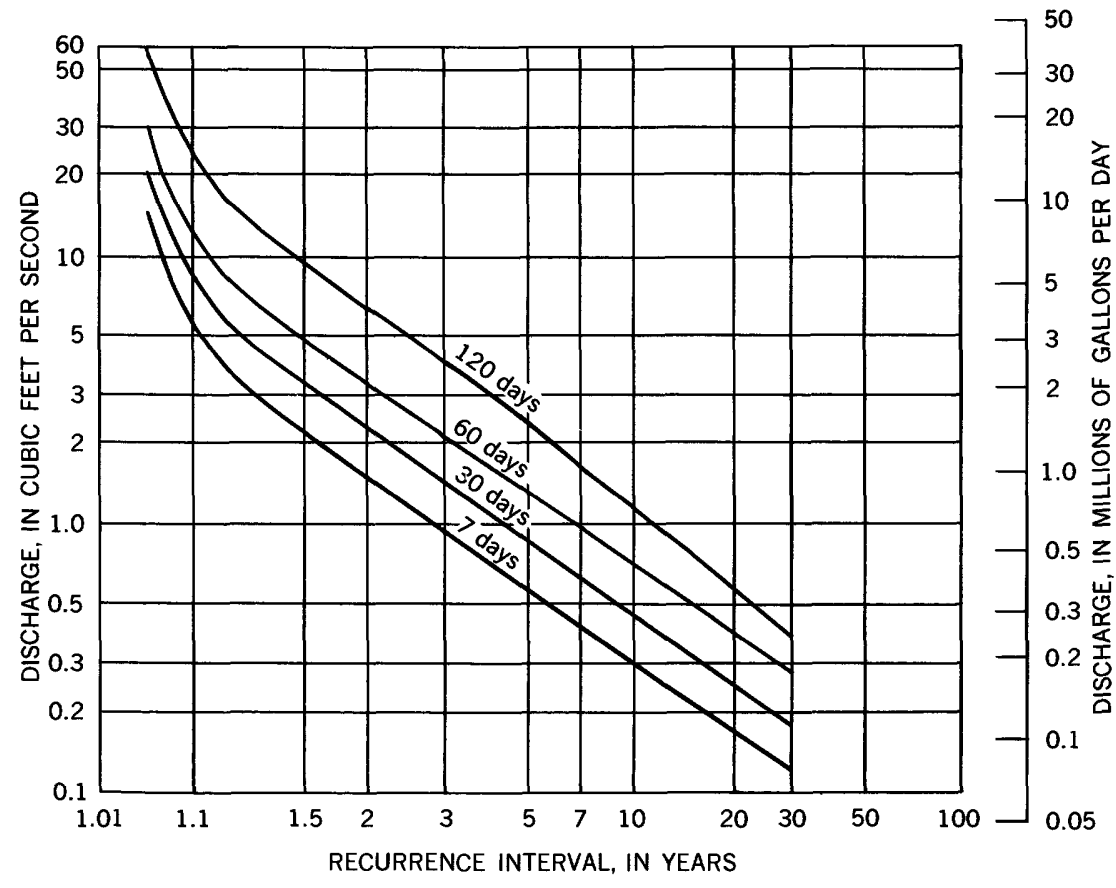

FTGURE 13.-Frequency of lowest average discharges for 7, 30, 60, and 120 consecutive-day periods at the South Middleton gaging station. (Base data adjusted by regional correlation.)

\section{BASE RUNOFF}

Base runoff in the Ipswich River basin is sustained largely by the discharge of ground water to the streams from adjacent unconsolidated deposits. Average annual base runoff at the Ipswich gaging station is estimated to be about 14.5 inches, and that at South Middleton station, about 12.3 inches (table 4). Thus base runoff comprises about 67 percent of the average annual discharge at Ipswich and about 55 percent of the annual discharge at South Middleton.

A significant amount of streamflow included in the figures for base runoff may be derived from water ponded on swamp surfaces. Swamps occupy nearly one-fifth of the land area in the basin, and they are known to store vast quantities of water. However, hydrologic conditions in the swamps are complex and it is not known how much of the stored water contributes directly to streamflow and how much infiltrates aquifers beneath the swamps and enters the streams at some later time. The large ratio of base runoff to total runoff in the basin above the Ipswich gage probably indicates a sizeable contribution to base runoff from the large swamp systems in the lower basin. 


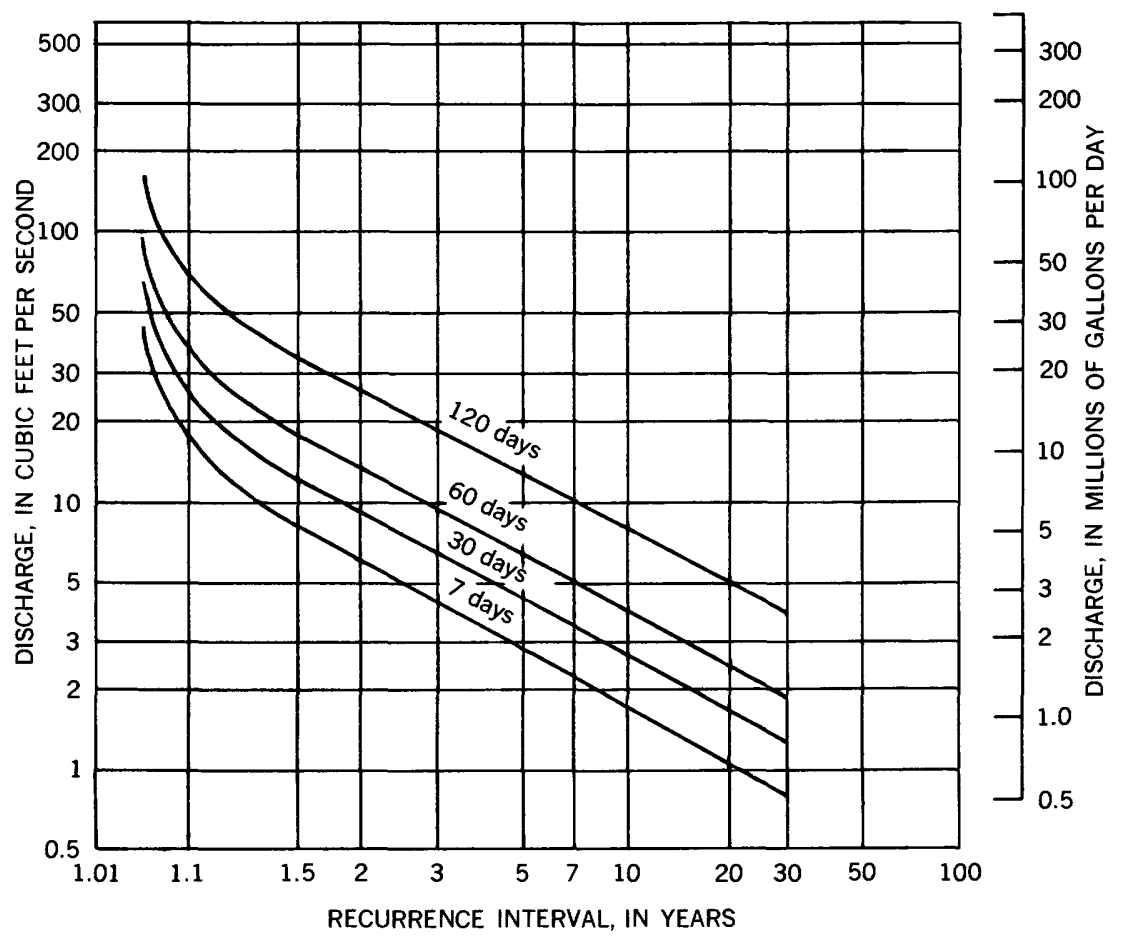

FIGURE 14.-Frequency of lowest average discharges for 7, 30, 60, and 120 consecutive-day periods at the Ipswich gaging station. (Base data adjusted by regional correlation.)

Amounts of annual base runoff at the South Middleton and Ipswich gaging stations (table 4) were computed by means of the relationship between the adjusted yearly runoff and estimated base runoff for those 10 years in which diversions were relatively small and constant and streamflow most nearly approached natural conditions.

Frequency curves of base runoff at the South Middleton and Ipswich gaging stations (fig. 15) indicate that annual base runoff per unit area at the gage near Ipswich is consistently greater than that at the South Middleton gage by about 20 percent. This difference in base runoff is probably only partly attributable to a difference in precipitation in the two areas inasmuch as the average precipitation in the Ipswich drainage area exceeded that in the South Middleton drainage area by only 2 percent during the period of record. Furthermore, the topographic and vegetal characteristics of both areas are similar. (See "Duration of flow" section.) Geologic mapping has shown, however, that in the lower basin the ratio of outwash deposits to other deposits is about 15 percent greater than in the upper basin. It is likely, 
therefore, that large volumes of outwash deposits, such as those that exist relatively far from principal drainage channels in Andover, North Andover, Middleton, and Boxford, contribute much of the additional base runoff in the lower drainage basin. These deposits, in conjunction with the large swamp systems, undoubtedly store much water during recharge periods and release it slowly during low-flow periods. Thus base runoff characteristics in the two parts of the basin appear to be related to geologic characteristics.

\section{FLOODS}

Overbank flooding occurs at places along the Ipswich River nearly every year, but catastrophic floods are rare. Only two major floods have been recorded in historic times, one in February 1886 and one in March 1936. The first of these is known only from accounts by local inhabitants. In Ipswich water reportedly rose as high as "the sidewalk on the river side of Market Street" (Thomson and others, 1964, p. 52). The river stage at this point must therefore have been at least 10 feet above normal stream levels, and perhaps was backed up by blockage at the historic Choate bridge a few yards downstream. The second major flood, that of March 1936, reached a peak flow of 2,610 cfs at the gaging station in Ipswich. This flood was not gaged at South Middleton, but it was there reported that the flood was the greatest since the flood of 1886 . It is not known how the two floods compare

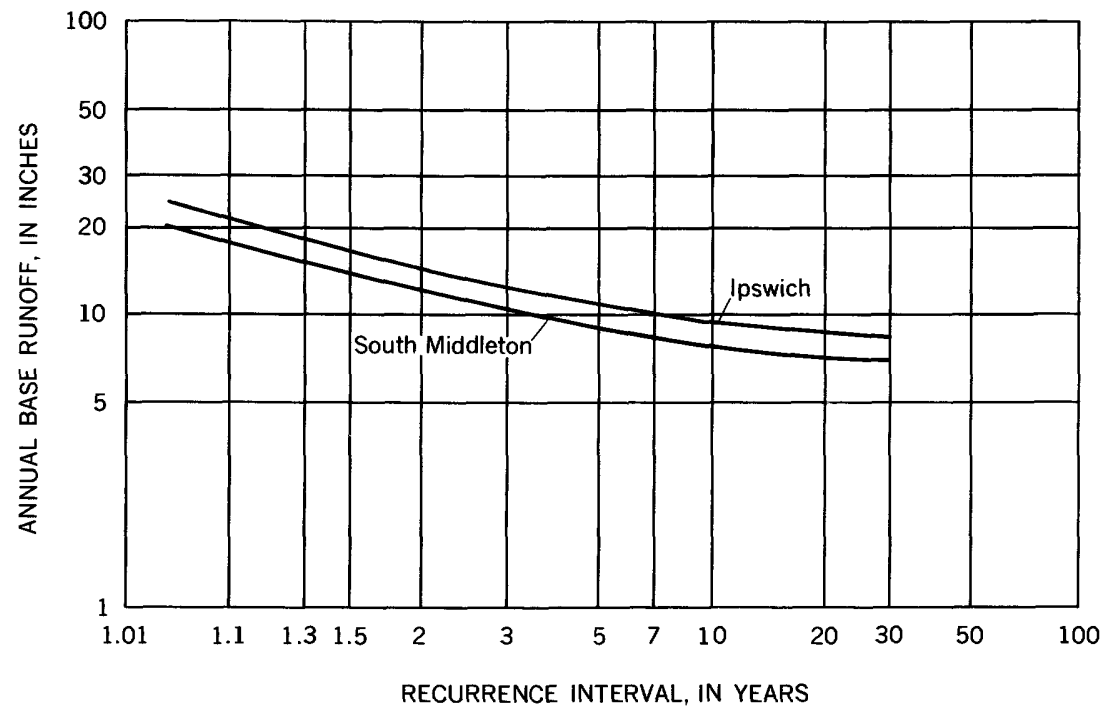

Figure 15.-Frequency of annual base runoff at the South Middleton and Ipswich gaging stations. 
in magnitude, but many residents of Ipswich reported that the 1886 flood was much higher than the one in 1936 (Thomson and others, 1964, p. 52, 81).

An apparent scarcity of reports of flood damage along the Ipswich River probably can be attributed to two causes. First, there has been little urbanization of the valley adjacent to the stream until recent years, and second, the wide swamps through which the river flows along much of its course are capable of storing tremendous quantities of flood discharge and releasing it slowly over a period of days or weeks. Increasing urbanization of the Ipswich basin will, however, not only contribute to larger flood flows in the stream, but will also increase the risk of damage when floods occur. A knowledge of high-flow characteristics is essential to the planning of many of the future developments in the basin.

Flood-frequency curves indicate the recurrence interval (in years) of momentary annual peak discharges (figure 16). The recurrence interval is defined as the average interval of time within which the given flood will be equaled or exceeded once (American Society of Civil Engineers, 1953, p. 1221). From a given recurrence interval it is possible to estimate the probability of a flood of given magnitude occurring in

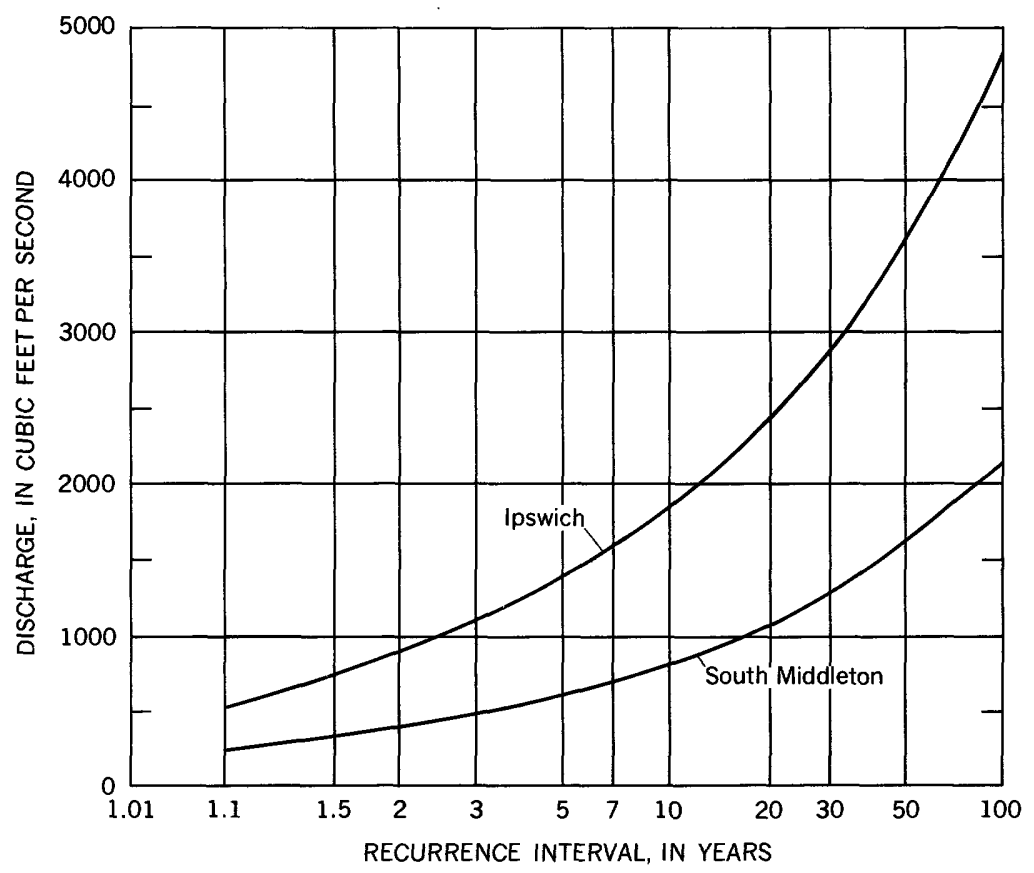

Figure 16.-Frequency of annual floods at the South Middleton and Ipswich gaging stations. 
any one year. For example, if the recurrence interval of a flood of given magnitude is 50 years, the probability of it occurring in any one year is 2 percent; similarly, if the recurrence interval is 25 years, there is a 4-percent probability of the flood occurring in any year, and so on.

The mean annual flood has been found to be the annual peak flow whose recurrence interval is about 2.3 years. At the Ipswich gage the mean annual flood is about $970 \mathrm{cfs}$, and at South Middleton it is 435 cfs. Nearly every year, peak flows exceed $500 \mathrm{cfs}$ at Ipswich and 250 cfs at South Middleton.

\section{DIVGRSION AND STREAM REGULATION}

Diversion of water from the Ipswich River basin occurs as the result of pumpage by six cities or towns. Beverly, Danvers, Lynn, Peabody, Reading, and Salem obtain all or part of their water supplies from the Ipswich River or from wells within the Ipswich River basin, and the waste water from these communities is released outside the basin. Much of the diversion occurs upstream from the South Middleton gage, and, during the period of record, diversions have ranged from about 1 to 29 percent of the annual runoff at South Middleton. For the last 5 years of the period of record (1956-60), the average annual diversion of water above South Middleton was 1,819 million gallons, or about 11 percent of the average annual runoff. Diversions from the basin above the Ipswich gage have ranged from about 1 to 16 percent of the annual runoff. The average annual diversion from the basin (1956-60) was 2,969 million gallons, or about 6 percent of the average annual runoff.

The stage hydrograph at South Middleton shows appreciable effects from municipal pumping, and at times of low or moderate flow, natural discharge may be reduced temporarily by more than 50 percent. During 1956 and 1957, flow in the Ipswich River ceased entirely for short periods in the vicinity of the Reading municipal well field, and it is estimated that as much as 35 square miles of the drainage basin contributed no water to the discharges measured at South Middleton. The report on ground-water conditions in the Wilmington-Reading area (Baker and others 1964) stresses the fact that excellent hydraulic connections exist between the Ipswich River and adjacent groundwater bodies, and it is clear that pumpage of ground water strongly affects streamflow in the Wilmington-Reading area. Downstream from the South Middleton gage, pumpage of water for use in the basin and diversions from the basin are small relative to total stream discharges, and the effects of pumping are not usually apparent in streamflow records obtained at the Ipswich station. However, changes in municipal water supply facilities, such as those introduced 
at Danvers in 1960, may eventually alter flow patterns in the lower Ipswich basin.

Discharge of the Ipswich River is occasionally affected by regulation at a mill upstream from the South Middleton gage. The effect of this regulation is usually perceptible at the South Middleton gage for no more than 24 hours, and the effect is too small to be discernible at the Ipswich station.

\section{WATHR LOSS}

The term "water loss" includes water lost to evaporation, transpiration, and ground-water flow (underflow) at the stream gages, as well as changes in the amount of soil moisture, surface retention, and ground-water storage. Average annual water loss for the upper part of the basin is 19.11 inches; the average loss for the entire basin is 20.49 inches. The figures for annual water loss in table 4 were obtained by subtracting the amounts of annual runoff from the annual precipitation.

Over a period of several years the average water loss in the Ipswich River basin is nearly equal to the amount of evapotranspiration from the basin. This is true only because other losses, such as underflow at the gaging station, are negligible, and because there is no long-term change in the amount of ground-water storage in the basin. Thus over a period long enough to average out annual fluctuations in storage, nearly all the difference between the amount of precipitation and the amount of runoff represents water lost through evapotranspiration. At the end of any one year, however, the difference between the annual precipitation and the annual runoff may include a large increase or decrease in soil moisture and ground-water storage in addition to the amount lost by evapotranspiration.

The average water loss computed for the Ipswich River basin above the gaging station near Ipswich is about 6.7 percent greater than the loss computed for the Wilmington-Reading area (table 4). This difference is large enough to suggest a dissimilarity in hydrologic characteristics between the upper and lower parts of the drainage basin. The nature of the dissimilarity is difficult to assess, particularly because the percentages of deposits that are assumed to have maximum evapotranspiration potential (swamps and low-level outwash deposits) are about equal in the two parts of the basin. A possible explanation is that there is a greater evaporation potential in the large, continuous swamp areas of the lower basin, typified by Wenham Swamp, than in the many shallow, discontinuous swamp areas of the upper basin. 


\section{QUALITY OF WATER}

Most natural waters in the Ipswich River basin are of suitable chemical quality for domestic and many industrial uses. The waters range from weakly alkaline to weakly acidic, and from soft to moderately hard. In addition to calcium (to which most of the hardness is attributable), the elements most commonly present in objectionable amounts are iron and manganese. These elements are in nearly all waters of the basin, and at many places concentrations are sufficiently high to require treatment prior to domestic and industrial use.

The major chemical constituents and properties of ground water in the Ipswich basin are listed in table 5, along with a brief summary of their significance for water use in this area. Chemical analyses reported by the Branch of Quality of Water of the U.S. Geological Survey are given in open-file reports for the Wilmington-Reading area (Baker and Sammel, 1961) and for the lower Ipswich River basin (Sammel and Baker, 1962). Table 6 of the present report summarizes the chemical analyses arranged according to the geologic source of the water sample. Statistical treatment has been limited to listing the range of concentrations and the median concentration of each chemical constituent.

Limits recommended by the U.S. Public Health Service (1962) for manganese and iron are $0.05 \mathrm{ppm}$ (parts per million) and $0.3 \mathrm{ppm}$, respectively. Of the 28 samples of ground water analyzed, the concentration of manganese exceeded the recommended limit in 11 samples, and the concentration of iron exceeded the limit in 8 samples. Table 7 shows amounts of iron and manganese in samples of river water taken at locations along the Ipswich River on the dates indicated. The concentrations of iron and manganese were highest in samples taken during the late summer, and the increase is attributed to the larger proportion of ground-water runoff in the streamflow.

In several samples of ground water, concentrations of nitrate were as high as $44 \mathrm{ppm}$. The usual sources of such contamination are sewage and agricultural fertilizers.

The chemical analyses show that concentrations of dissolved substances differ widely from place to place. Iron and manganese are the most common objectionable constituents, and in general, the samples that contain the highest concentrations of iron and manganese also contain the largest total amounts of dissolved solids. Concentrations of individual constituents and the total amounts of dissolved solids are apparently unrelated to the geologic unit from which the water samples were obtained. 


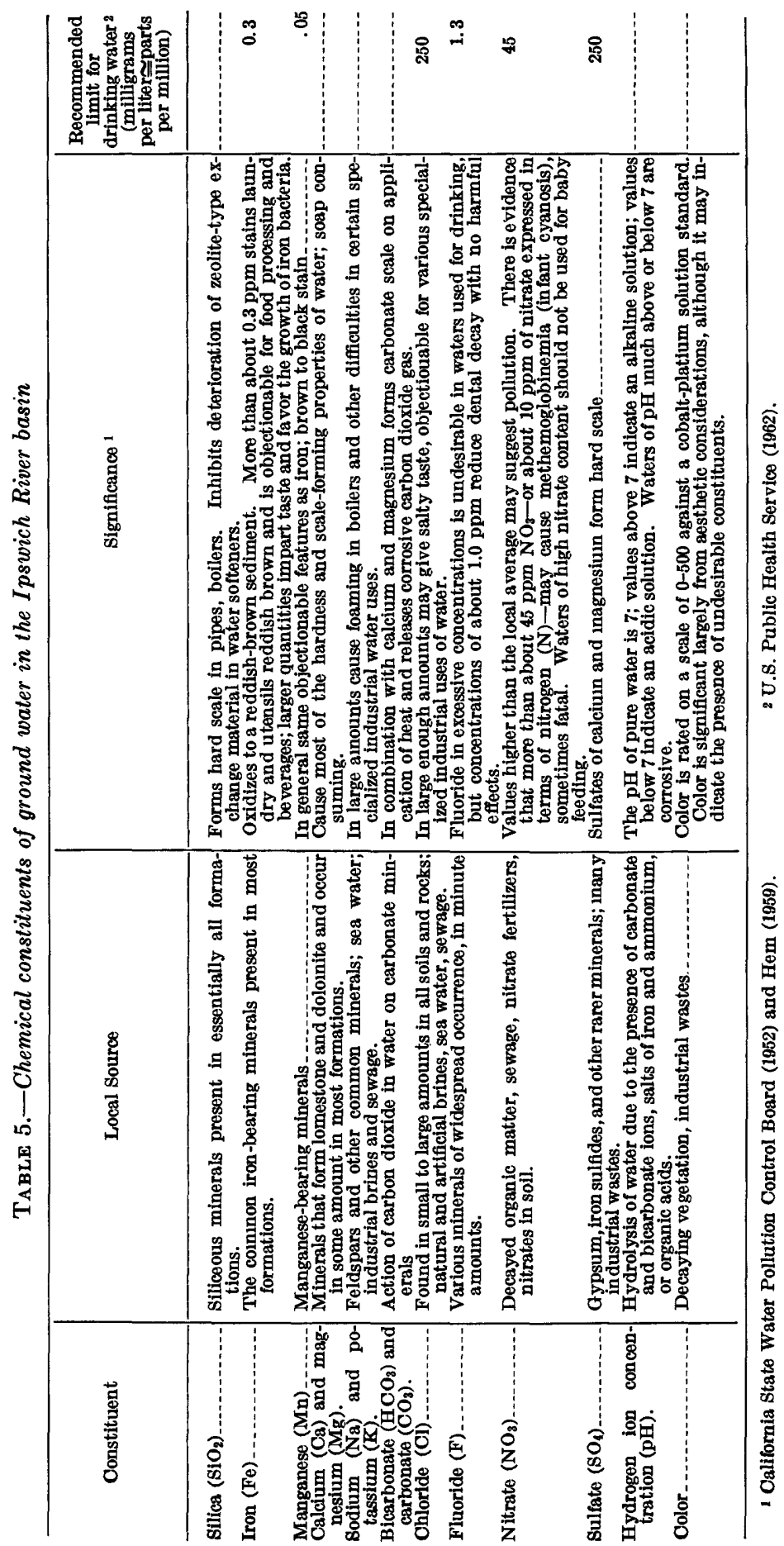




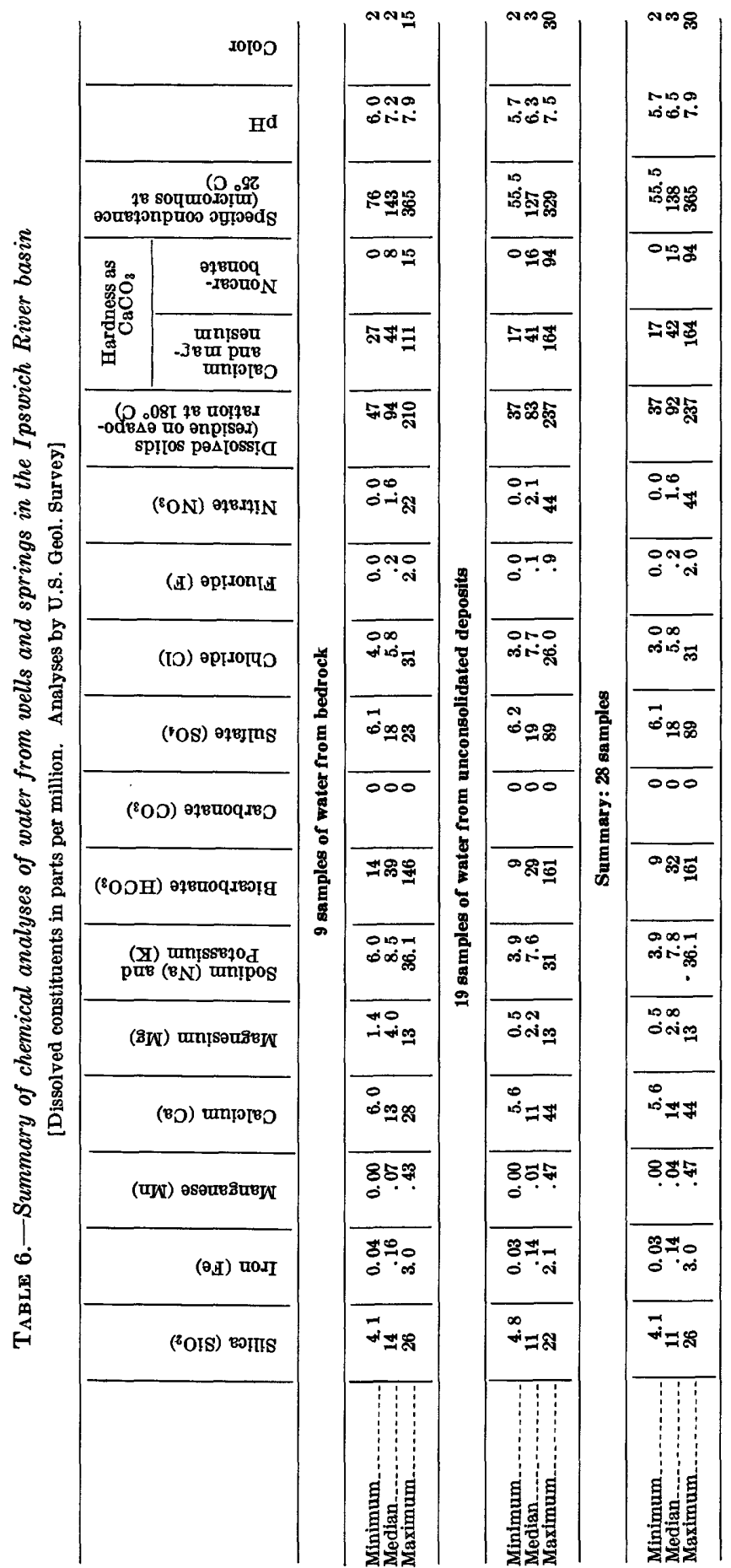


TABLE 7.-Concentrations of iron and manganese in samples of water from the Ipswich Rvver

[Analyses by U.S. Geol. Survey]

\begin{tabular}{|c|c|c|c|c|}
\hline Location & Dates & $\underset{(\mathrm{ppm})}{\text { Iron }}$ & Mn (ppm) & $\underset{\left({ }^{\circ} \mathrm{F}\right)}{\text { Temp. }}$ \\
\hline Burlington St., Wilmington & $\begin{array}{l}9- \\
4-20-58\end{array}$ & $\begin{array}{r}0.19 \\
.13\end{array}$ & $\begin{array}{r}0.00 \\
.01\end{array}$ & 54 \\
\hline Route 28, Reading & $\begin{array}{r}8-13-59 \\
10-2-58 \\
4-20-59 \\
8-13-59\end{array}$ & $\begin{array}{r}.37 \\
.59 \\
.45 \\
.80\end{array}$ & $\begin{array}{r}.01 \\
.03 \\
.00\end{array}$ & $\begin{array}{l}67 \\
51 \\
52 \\
70\end{array}$ \\
\hline Federal St., Wilmington_.-- & $\begin{array}{l}9-30-58 \\
4-20-59 \\
8-13-59\end{array}$ & $\begin{array}{l}.30 \\
.46 \\
.69\end{array}$ & $\begin{array}{l}.06 \\
.00 \\
04\end{array}$ & $\begin{array}{l}52 \\
50 \\
69\end{array}$ \\
\hline Wills Brook, Lynnfield & $10-2-58$ & .33 & .04 & 52 \\
\hline Route 62, Middleton. & 4-20-59 & .33 & .03 & 52 \\
\hline Route 114, Middle & $\begin{array}{l}8-1: \\
4-21\end{array}$ & $\begin{array}{l}.72 \\
.28\end{array}$ & $\begin{array}{l}.06 \\
.04\end{array}$ & $\begin{array}{l}71 \\
52\end{array}$ \\
\hline Salem Street, Topsfield & $4-20-59$ & .22 & .01 & 53 \\
\hline Winthrop Street, Hamilton & $4-20-59$ & .12 & .01 & 53 \\
\hline
\end{tabular}

Compositions of water samples from the stratified drift are similar to those from bedrock. Only two significant differences between the groups appear in the samples analyzed. Concentrations of iron and manganese are appreciably higher in water samples from bedrock, and the hardness is somewhat greater in water from the stratified drift.

The chemical relationships of the samples of ground water are presented in the trilinear diagrams of figures 17 and 18. (See Piper, 1944 , for a discussion of trilinear chemical diagrams.) The diagrams, which include only data on concentrations of ionized substances, show that, although there is a considerable amount of scatter in the anion fields, the cations are tightly grouped. Projections onto the diamondshaped field fall within an area in which water quality is dominated by the alkaline earths, calcium and magnesium. The dominant characteristic of the samples containing large amounts of dissolved solids (large circles) is that of relative hardness, both carbonate and noncarbonate. On the other hand, in samples containing small amounts of dissolved solids, no cation-anion pair predominates over the others. The diagrams further demonstrate that, with the possible exception of the carbonate contents, there is little difference between the quality of water derived from bedrock and the quality of water derived from unconsolidated deposits.

Temperatures of water measured in 115 wells in unconsolidated deposits range from $44^{\circ}$ to $62^{\circ} \mathrm{F}$. The water temperatures recorded in three wells in bedrock are $48^{\circ}, 52^{\circ}$, and $52^{\circ} \mathrm{F}$. The average temperature in all wells measured is $53^{\circ} \mathrm{F}$, which is about $4^{\circ} \mathrm{F}$ higher than the mean annual air temperature in the basin. Nearly all the temper- 


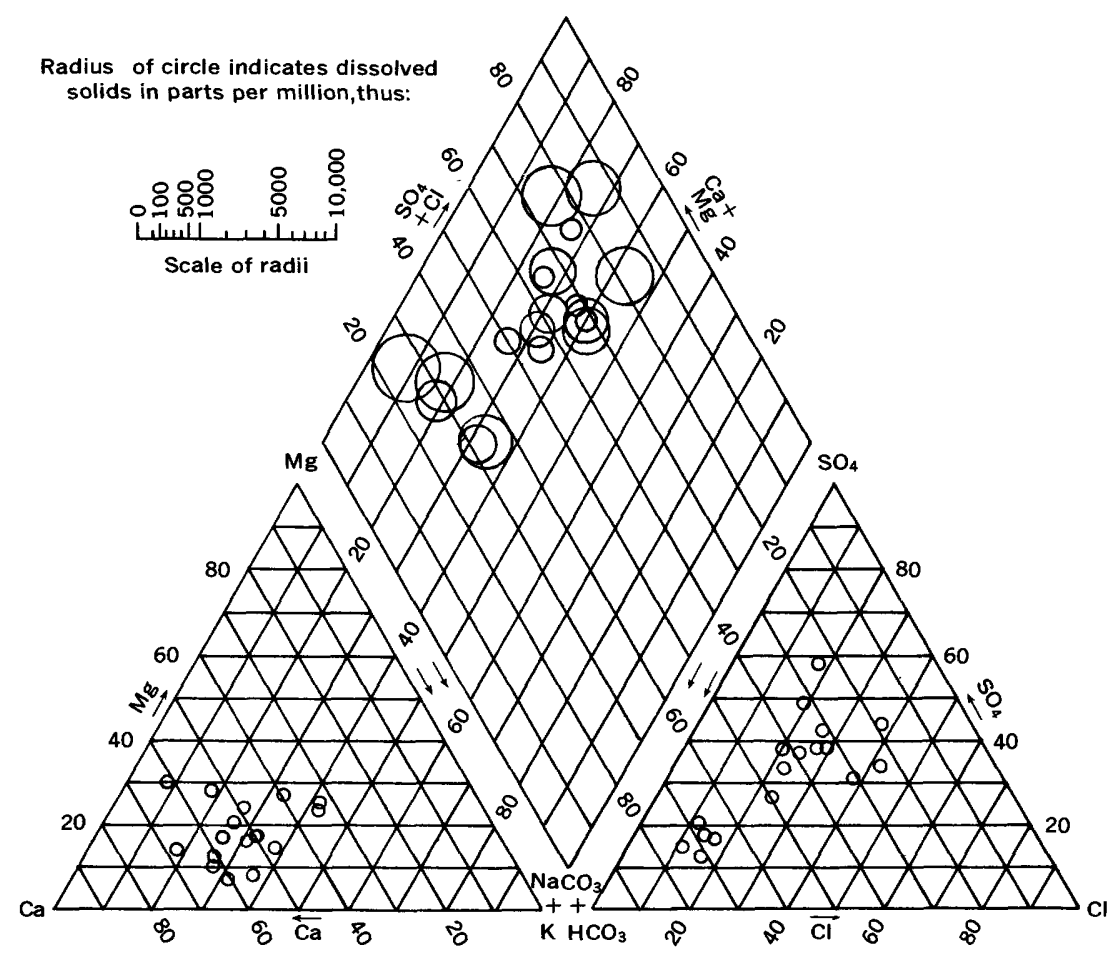

FIGURE 17.-Relative amounts of selected chemical constituents in 17 samples of ground water from wells penetrating unconsolidated deposits.

ature measurements were made during the summer months, and it is assumed that the average temperature computed from these measurements reflects the influence of summer air temperatures. Groundwater temperatures in individual wells in the area have been observed to fluctuate within a range of about $10^{\circ} \mathrm{F}$ during the year. Surfacewater temperatures fluctuate through a wide range, and although few measurements are available as evidence, it is assumed that the range of temperatures in most surface-water bodies approaches the range of the mean monthly air temperatures.

Stream pollution occurs at many places in the basin as the result of discharge of both industrial and domestic wastes. A study by the New England-New York Inter-Agency Committee (NENYIAC, 1955, sec. V, p. 1-70) determined that the entire main stem of the Ipswich River and many of its tributaries were polluted and that, in certain areas, pollution was relatively severe, especially during periods of low flow. In most of the main channel and in all but two of the major tributaries, pollution was not objectionable and the waters were classified as being in Condition II, which corresponds to New England 


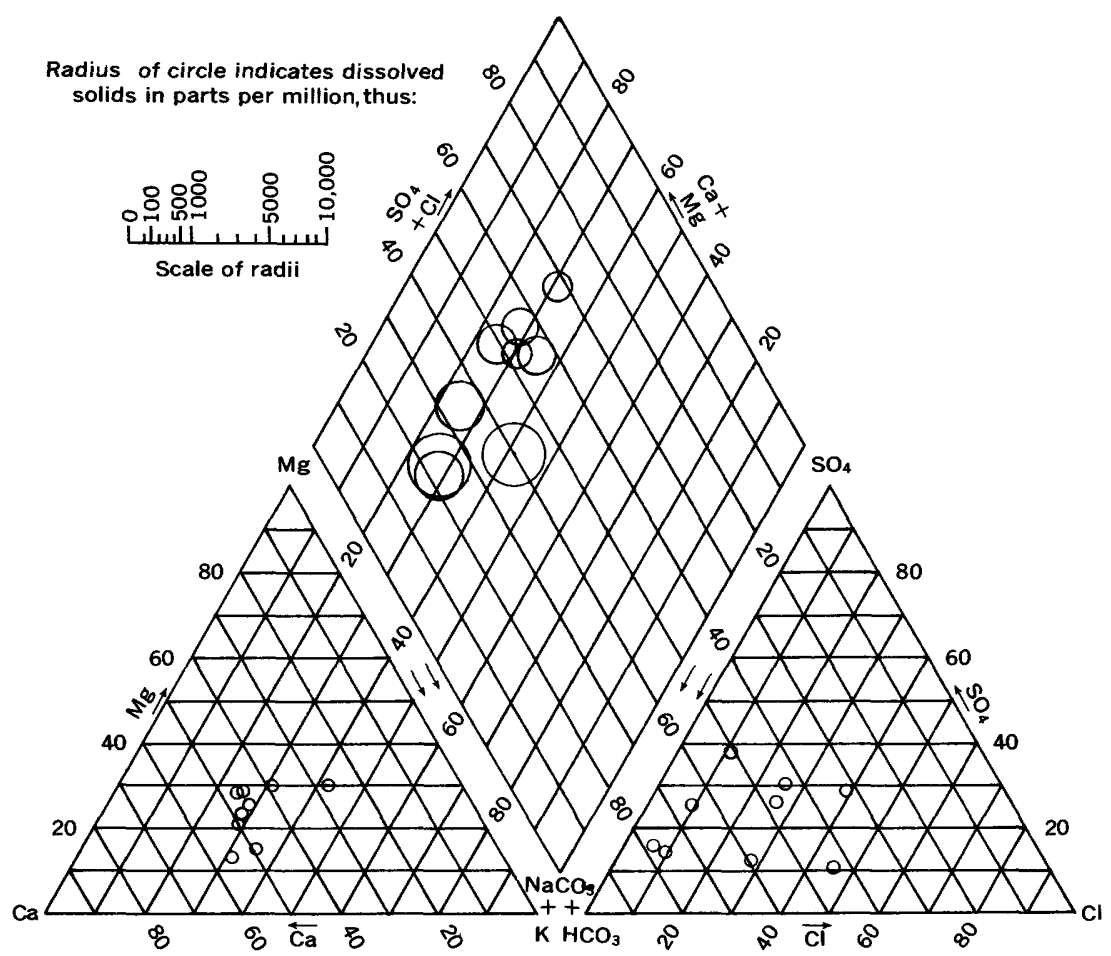

Frgure 18.-Relative amounts of selected chemical constituents in nine samples of ground water from wells penetrating bedrock.

Interstate Water Pollution Control Commission classification B: "Suitable for bathing and recreation, irrigation and agricultural uses; good fish habitat; good aesthetic value. Acceptable for public water supply with filtration and disinfection." Diversions for the municipal supplies of Salem, Beverly, Lynn, and Peabody are made from waters of this class.

The NENYIAC (1955, sec. V, p. 16-19) describes pollution in excess of the standards for Condition II in 1.5 miles of Lubber Brook, 1 mile of Martins Brook in Wilmington, and the lower 4 miles of the main channel in Ipswich. During the years since the study was made for the NENYIAC report, two of the sources of pollution have been eliminated by the closing of a tannery on Lubber Brook and by the installation of a sewage-treatment facility in Ipswich. As of 1962, no additional changes are reported by the Massachusetts Department of Public Health, and it is assumed that stream conditions in 1962 are generally similar to those described in the NENYIAC report. 


\section{WATER USE}

\section{AGRICULTURE, INDUSTRY, AND PUBLIC SUPPLY}

Annual withdrawal of water in the Ipswich River basin fluctuates widely from year to year. Since 1931 annual pumpage has ranged from about $2 \mathrm{mgd}$ in 1939 to $13.9 \mathrm{mgd}$ in 1958. (See fig. 19.) Much of the fluctuation in demand is due to variations in the water needs of Lynn, Peabody, and Salem, all of which divert streamflow from the basin for municipal supply. Changes in use from year to year in these municipalities result partly from variations in climate and partly from variations in industrial demand for water. A 5-year running average of annual withdrawals indicates that use of water from the Ipswich basin has more than doubled since 1931.

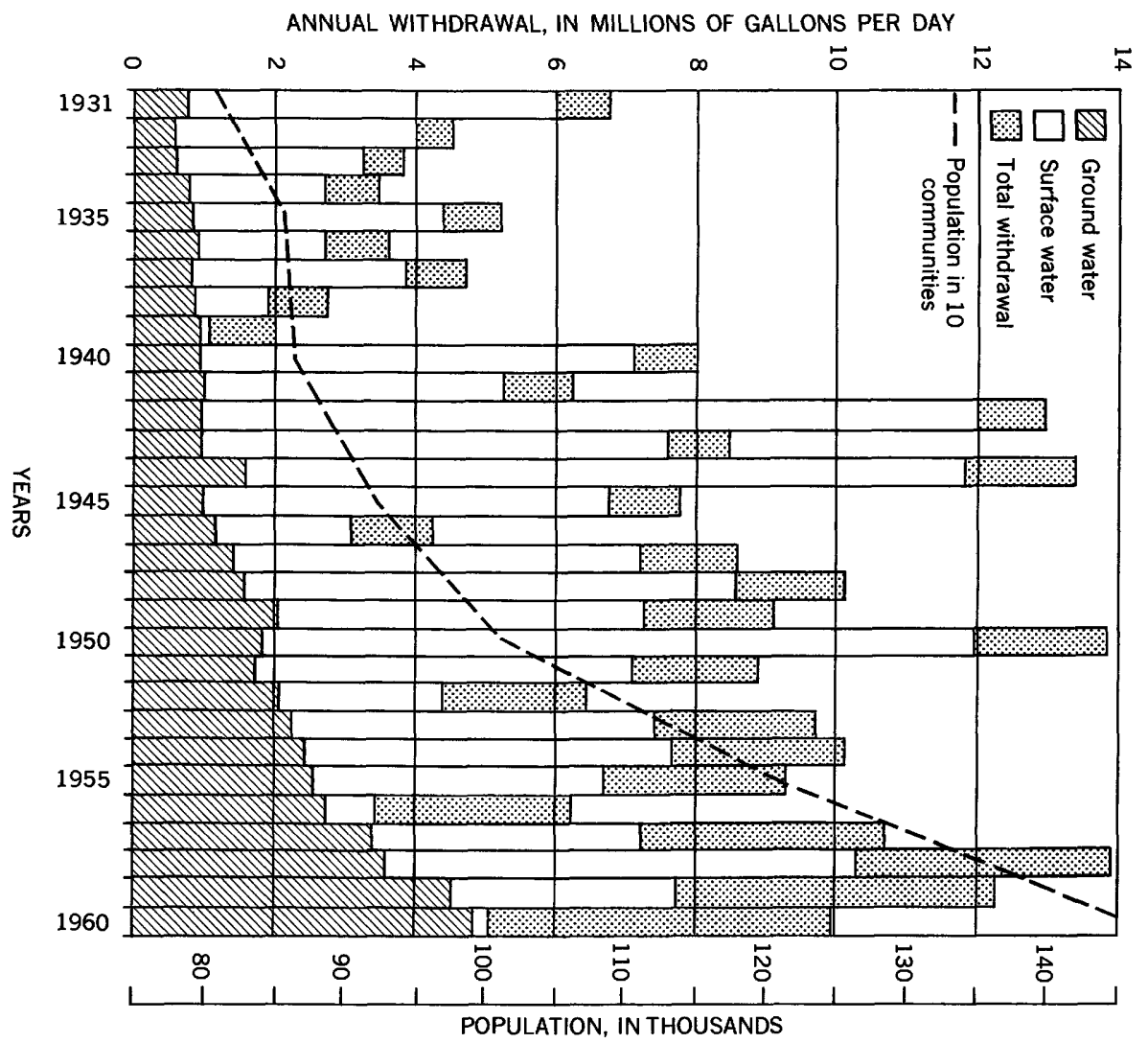

Frgure 19.-Annual withdrawals of water and population trends in $10 \mathrm{com}$ munities in the Ipswich River basin (1931-60). 
Use of ground water in the Ipswich River basin has increased steadily from about $0.7 \mathrm{mgd}$ in 1931 to about $4.8 \mathrm{mgd}$ in 1960 (fig. 19). Amounts of ground water used annually show only small changes from year to year. Ground water is supplied mostly for domestic rather than industrial use, and the increase in use since 1931 reflects primarily the population growth in the towns served.

During the years 1930-60 the total population served by water withdrawn from the basin increased from about 226,500 to about 379,000 . The rate of increase implied by these figures is somewhat misleading, inasmuch as the two largest municipalities, Lynn and Salem, actually decreased in population during this period. The population graph in figure 19 shows the population increase between 1930 and 1960 in 10 communities which are the areas of future major growth. Not included in the graph is the town of Ipswich which derives its municipal water supply from sources outside the Ipswich River basin and which disposes of most of its imported water downstream from the gaging station at Ipswich.

Diversions of water from the Ipswich River basin constitute a large share of the total use of water, although the proportion of diversions to total water use has decreased over the years. The decrease is illustrated by the fact that, for the period 1931-35, average annual diversions amounted to 96 percent of total water use, while for the period 1956-60, the average diversion was 76 percent of the water use. The relative change is largely due to population growth rates, which were higher for towns in the basin than for the towns nearer Boston to which pumpage was diverted.

Per capita use of water from the basin has increased during recent years. Combined data from three representative communities. Hamilton, Reading, and Wilmington, show that over a 20 -year period of record the per capita use of water has increased from about 55 to 79 gpd (fig. 20). The change represents increases in both industrial and domestic use.

Water distributed in communities within the basin is used mostly for domestic purposes. Little or no industrial use of water is reported in towns within the basin except for Wilmington, where three industrial concerns use about 40 percent of the total pumpage. Although agricultural use of water occurs in all communities, the amounts used each year are relatively small. Much of the water used for agricultural purposes is derived from private sources mainly during June, July, and August of each year.

Much of the water diverted from the basin is used for industrial or commercial purposes, predominantly in Peabody, Salem, and Lynn. According to data compiled for the report by the New England-New York Intêr-Agency Committee (1955), industrial use of water in these 


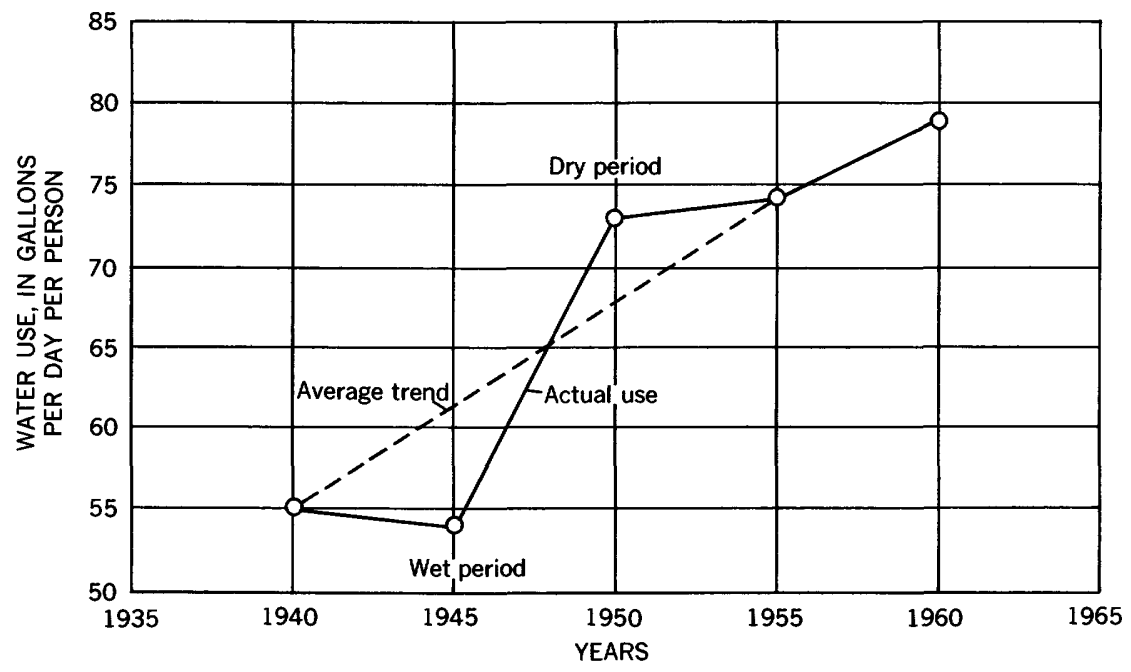

Figure 20.-Per capita use of water in the towns of Hamilton, Reading, and Wilmington.

cities ranged from about 52 to 93 percent of total fresh-water use. It is estimated, however, that amounts of water used industrially have decreased greatly in recent years, in some years to about one-third the percentage reported for the early 1950's although percentages used commercially (for air conditioning and other uses) have probably increased.

Statistics relating to municipal water supplies withdrawn in the Ipswich River basin are given in table 8. A small amount of water is withdrawn by private owners for domestic and agricultural use, mostly in the towns of Boxford, Andover, and North Andover where there is no public supply. It is estimated, however, that all nonmunicipal use of water adds less than 5 percent to the figures for municipal use.

\section{RECREATION}

The use of water for recreation is important in the Ipswich River basin. About 40 major ponds, in addition to many miles of stream channel, provide opportunities for fishing, boating, hunting, and swimming. The public is permitted to use all major water bodies in the river basin except for Wenham Lake and Longham Reservoir in Wenham and Putnamville Reservoir in Danvers. A limited number of permits are issued for the recreational use of Middleton Pond in Middleton and Swan Pond in North Reading. The State maintains two recreation areas within the basin-the Bradley W. Palmer State Park in Hamilton and the Harold Parker State Forest in Andover. Both of these facilities depend to some extent on water resources for their recreational appeal. 
WATER USE

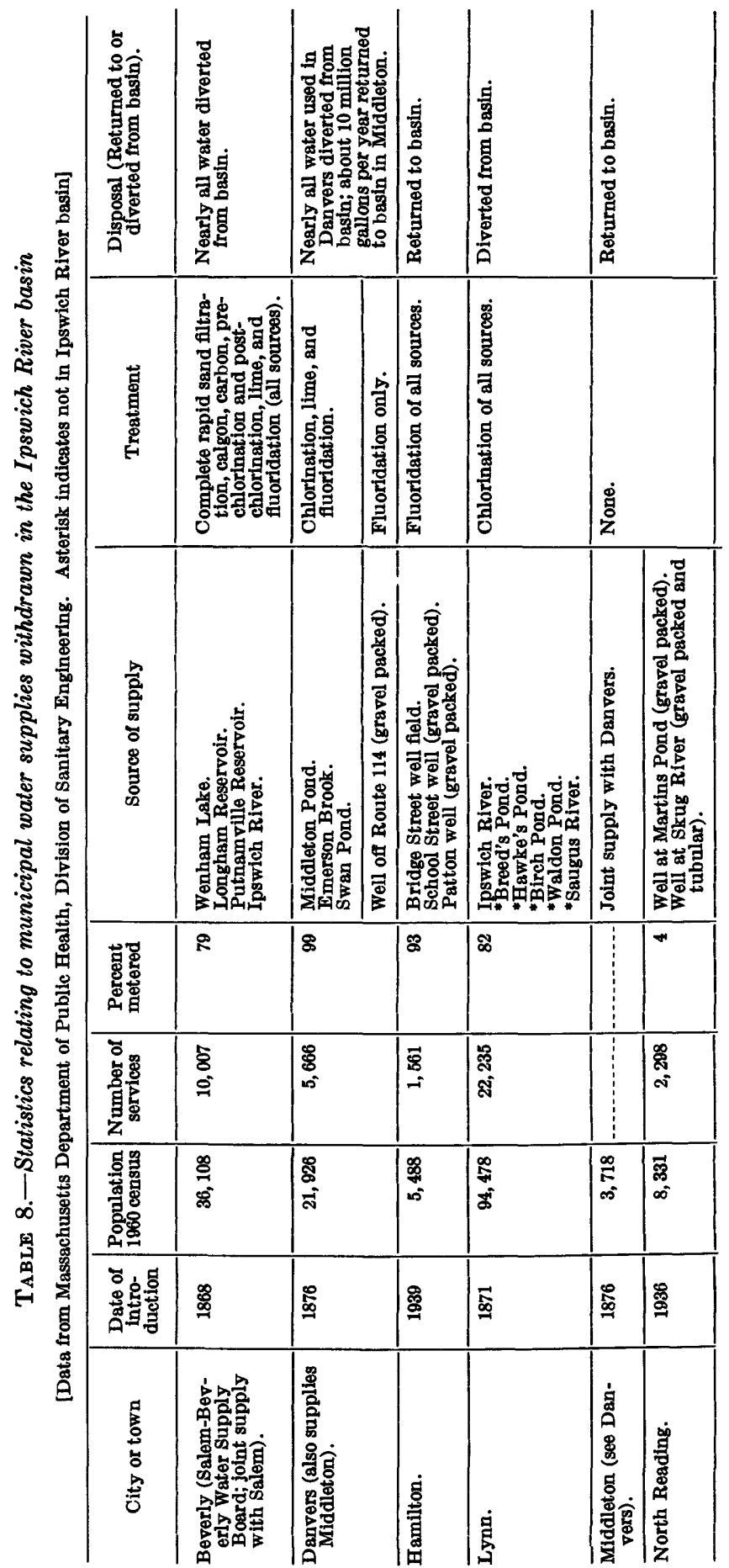




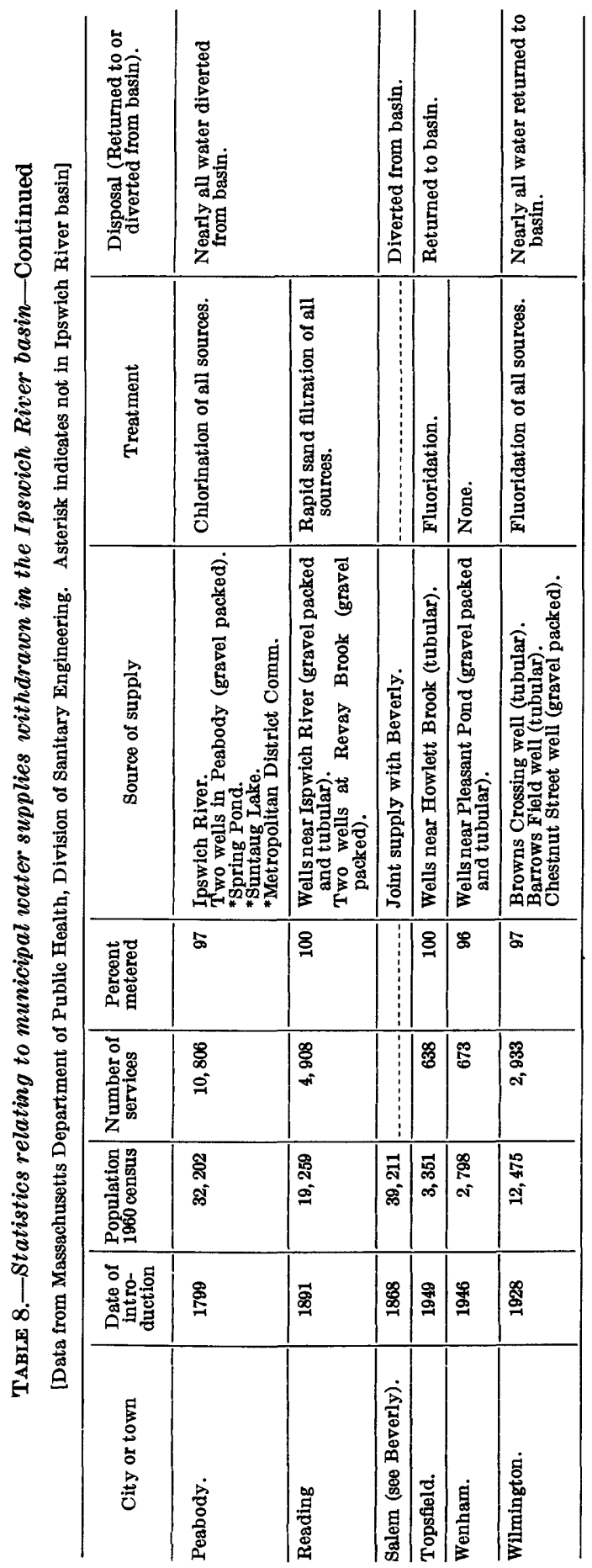


The quality of water in the major surface-water bodies is generally good for any recreational use. The few known exceptions are described in this section of this report dealing with quality of water.

\section{WATER-RESOURCES DEVELOPMENT}

Trends of population growth in communities within the basin indicate that by the year 2000 the present population of the area will be doubled. If the trend of water use in relation to population growth continues to rise, the use of water from the basin will probably increase to more than twice the present use during this same period. This section of the report summarizes data which may be of use in assessing the capacity of the river basin to provide the water required for future needs.

The average rate of runoff from a river basin provides a measure of the theoretical upper limit of sustained water use. In the Ipswich basin, the average use of water in the period from 1958 to 1960 amounted to less than 10 percent of the theoretical limit of use (fig. 21). In the Wilmington-Reading area, use was about 16 percent of the long-term average runoff; in the downstream part of the basin, use was about 6 percent of the average runoff.

Although the foregoing percentages indicate that a great increase in water use is theoretically possible, they are of little value in determining the practical limits of future development. The complex problems of water-supply development require simultaneous consideration of such factors as the availability of surface- and groundwater storage, transmissibility of ground-water aquifers, relationship of storage changes to streamflow, amount and nature of base flow, low-flow characteristics of streams, reuse of water within the basin, and many other factors of both local and regional importance. Although the scope of this investigation does not permit a detailed analysis of local water-developed potential, this report and the report on ground-water conditions in the Wilmington-Reading area (Baker and others, 1964) include data which should facilitate consideration of the essential hydrologic factors. The data on low-flow frequencies (figs. 13 and 14) provide a partial basis for estimating the storage necessary to sustain any desired pumpage from streamflow, and they provide information which should be helpful in predicting effects of ground-water withdrawals and storage.

Graphs of precipitation frequencies for the months of April through October (fig. 22) may be useful in estimating potential use of water resources during critical months of each year. Although these data were obtained from only one precipitation station, the resulting frequency curves are assumed to represent conditions over most of the 


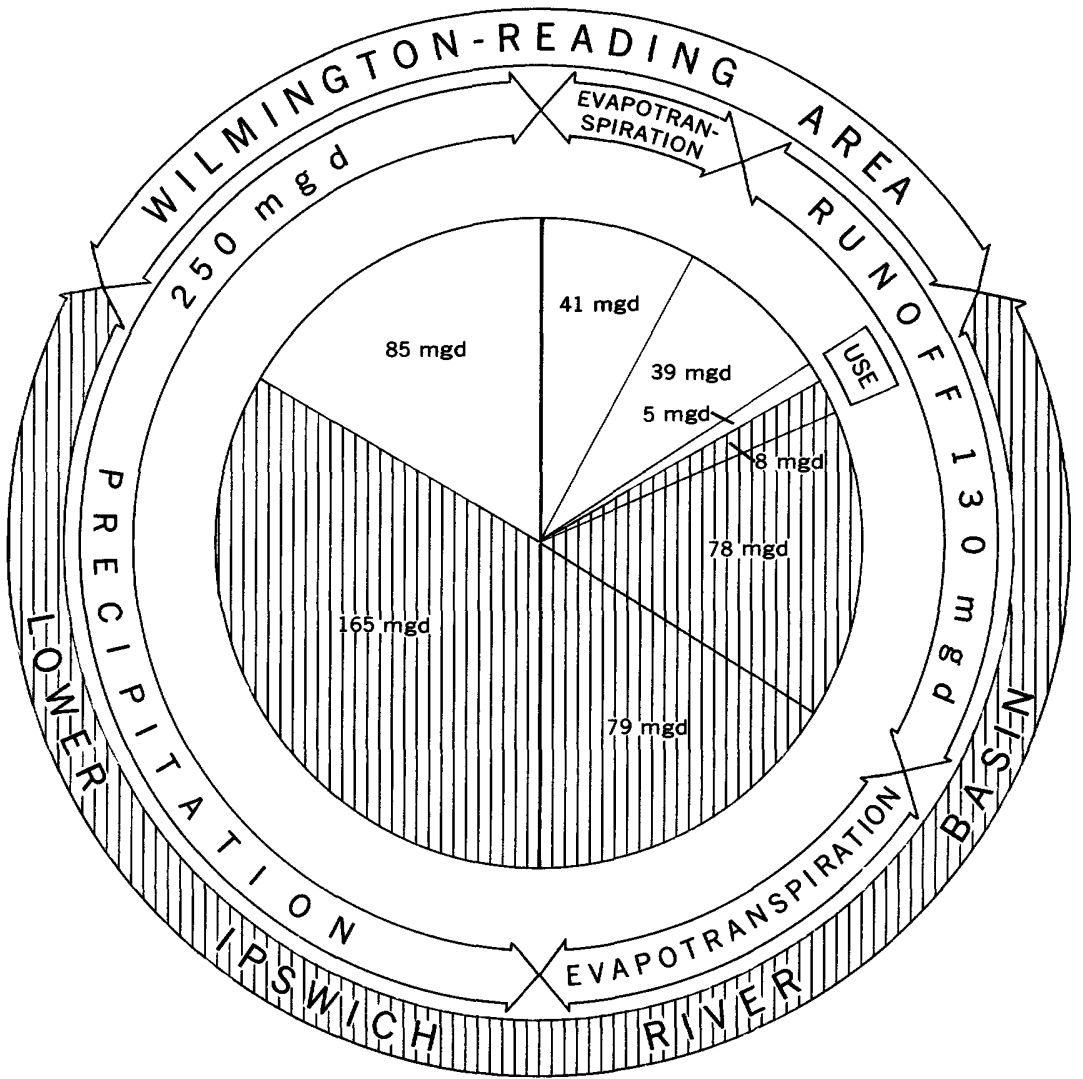

Figure 21.-Average annual precipitation, evapotranspiration, and runoff (1931$60)$ and average annual use of water (1958-60).

river basin. The frequency curves can be used to estimate the probability of occurrence of specified amounts of precipitation during the growing season.

Estimates of effective annual recharge to unconsolidated aquifers provide a measure of the potential availability of ground water. The effective annual recharge to aquifers in the Wilmington-Reading area is estimated to be no less than 4 inches ( $8.3 \mathrm{mgd})$, and effective annual recharge in the lower basin is estimated to be no less than 4.4 inches (16.9 mgd). The 1960 rates of ground-water use (fig. 19) therefore represent about 50 and 10 percent, respectively, of the conservatively estimated yields that could be sustained in the two parts of the basin.

The ability of an aquifer to sustain a given yield throughout the year depends on its ability to store enough water to sustain the given yield during the approximately 150 days each year when ground-water recharge is negligible. Estimates of storage capacity in the Ipswich 
River basin indicate that aquifers could yield an amount of water equal to the average annual recharge by dewatering about 1 foot of the aquifer during the summer months. Although the full potential of all aquifers in the basin undoubtedly will never be realized, the above figures afford assurance that greatly increased use of ground water could be sustained by maximum exploitation of available aquifers. Areas which appear to be favorable for further development are described in the Wilmington-Reading area report and in the section of the present report headed "Development of ground water in the lower Ipswich River basin".

In considering the development of surface-water supplies from streamflow, it is apparent that pumpage during low-flow periods could be increased very little in the Wilmington-Reading area and only moderately in the lower river basin. The low-flow frequency curve for the stream-gaging station at South Middleton (fig. 13) indicates, for example, that an average flow of $1 \mathrm{mgd}$ for 120 consecutive days occurs about once in $71 / 2$ years, and the probability of occurrence in any one year is therefore about 13 percent. At the gaging station near Ipswich, streamflow averages less than $1 \mathrm{mgd}$ for

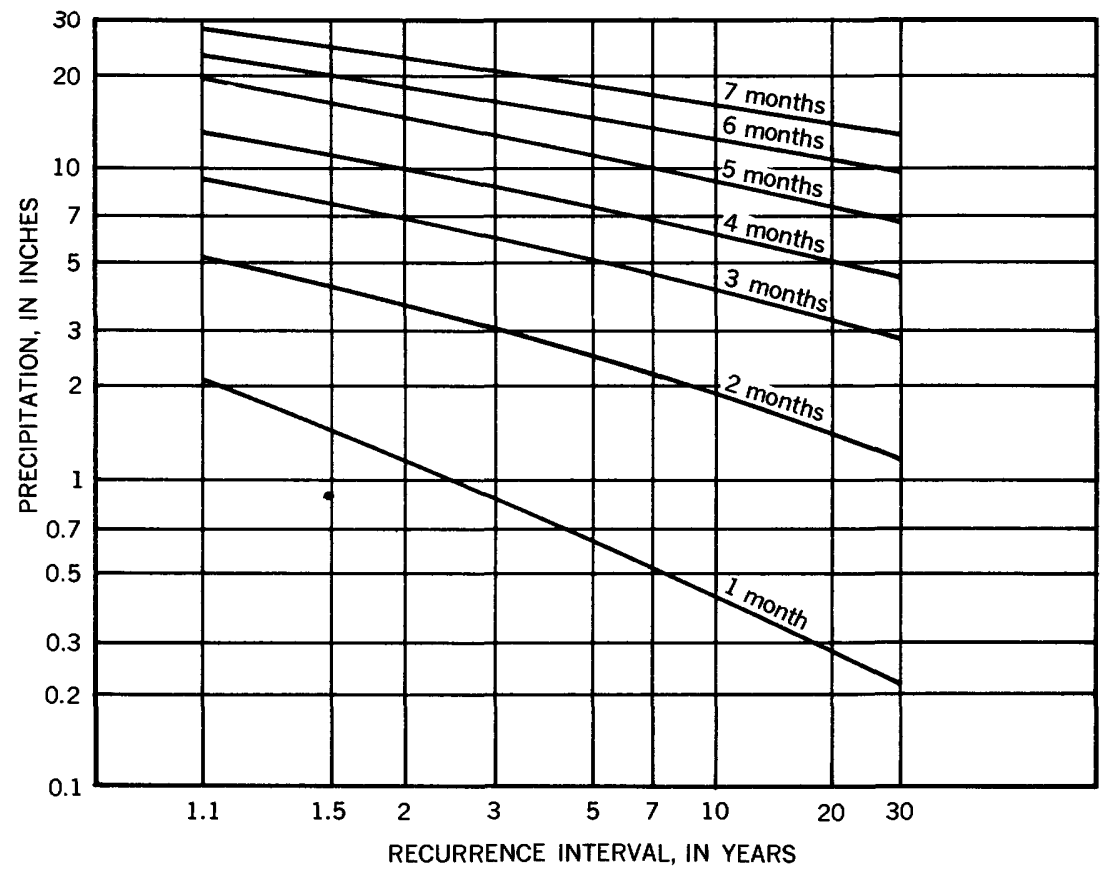

Fraure 22.-Frequency of lowest precipitation for periods ranging from 1 month to 7 consecutive months during the growing season (April to October) at Middleton. 
30-day periods about once in 20 years and the probability of this occurence each year is about 5 percent. Average minimum flows are about $1 \mathrm{cfs}$ at the South Middleton gage and about $4 \mathrm{cfs}$ at the Ipswich gage.

Any substantial increase in the pumpage of streamflow from the Ipswich River basin will necessitate the use of storage facilities which allow pumpage of high flows for use during low-flow periods. Estimates of possible rates of surface-water withdrawal can be made from data available in the files of the Branch of Surface Water, U.S. Geological Survey, whenever one desires to relate these data to specific volumes of storage and predicted rates of use.

The ponds within the drainage basin are potential sources of water supply. Such sources have not been investigated in detail for this report. Many of the ponds are merely depressions in a generally swampy surface, and their use for water supply would necessitate extensive treatment of the water for removal of color, odor, and in most places, excessive amounts of iron and manganese. Most of the ponds capture runoff from very small watersheds, and hence pumpage from these sources would largely be ground-water withdrawal. In addition, these ponds that would provide the best conditions for use as water supplies have been preempted to a large extent for recreational use. Although certain limited recreational uses of small lakes are not incompatible with water-supply use, the tendency at present is to look elsewhere for water-supply and to leave the ponds for unrestricted use. Ponds currently in use as water-supply or storage reservoirs are listed in table 8.

It should be remembered that development of either ground water or surface water can not occur irrespective of each other. The close relationship between ground- and surface-water supplies has been amply documented by the Wilmington-Reading report and the section, "Diversions and stream regulation" in the present report. The hydrologic principles that underlie this relationship are true anywhere in the river basin. An increase in the withdrawal of ground water at any point will have some effect on streamflow, particularly on base flow, downstream from that point. New wells near stream channels will intercept potential base flow and, if drawdowns from such wells intersect the stream channels, streamflow will be captured. In the drainage basin above South Middleton, the existing municipal supply wells and most of the areas that are favorable for further development of ground water are adjacent to stream channels. It may be assumed, therefore, that large increases in the withdrawal of ground water will result in appreciable reductions of streamflow during base-flow periods. 
The nature and magnitude of the effects of increased ground-water withdrawals will depend greatly on whether the water withdrawn is diverted from the basin, wasted to a stream from a central point, or returned to the ground at numerous points within the basin. At the Reading well field, for example, where wells obtain much of their recharge from the river, water withdrawn from the wells is diverted from the river basin and, as a consequence, streamflows downstream from the well field are seriously reduced during most low-flow periods. In Topsfield, on the other hand, ground-water withdrawal occurs relatively far from the main channel of the river, and the water is returned to the ground at many points within the town. Under these conditions, ground-water withdrawal probably does little to alter base flows in the river except for the reduction of flow due to a presumed slight increase in the amount of water lost through evapotranspiration. Development of additional ground-water supplies could therefore occur in several areas of the lower Ipswich River basin with relatively little reduction of low flows in the Ipswich River, but only in areas remote from major stream channels and if waste disposal would replenish aquifers at a rate approaching the rate of withdrawal. Areas in which these conditions can exist are probably found only in the rural parts of Andover, Boxford, and northwestern Ipswich. Additional pumpage of ground water from the entire Miles River subbasin in Hamilton and Wenham would reduce streamflow only in the lower few miles of the Ipswich River and would have no effect on flows measured at the gaging station near Ipswich.

In the lower Ipswich River basin, induced infiltration of streamflow to ground-water aquifers probably occurs along the Ipswich River at the Danvers and Middleton municipal supply wells. Induced infiltration at both of these sites is postulated largely on the basis of the proximity of the wells to the river, the known geology of the area, and an analogy to hydrologic conditions at the Reading municipal well field. No estimate of the amount of induced infiltration is available, but it is assumed that a large increase in ground-water pumpage at these or other similar locations would be reflected in a reduction of low-flow stages downstream.

As the converse of the situation in which withdrawal of ground water reduces flow in a stream, reduction of streamflow may cause a decrease in the withdrawal of ground water. Data from the municipal well field in Reading show that a decline in stage of the river results in increased drawdowns in the adjacent wells, and when the drawdowns become critically large pumping rates are reduced. Therefore, the inability of a stream to supply all the induced recharge needed during a long low-flow period could result in both drying up the 
stream and reducing the amount of available water from a well field. These effects can occur as the result of many conditions that tend to reduce streamflow during low-flow periods. Thus, swamp drainage and channel dredging, diversions of streamflow to other basins, and pumpage of ground water so as to divert potential base flow would tend further to reduce low streamflows, and each could also reduce ground-water withdrawals at points downstream.

Large increases in diversions from the basin are possible if adequate discharges are maintained during low-flow periods. At the present time, diversions of streamflow from the basin occur almost entirely during periods of high stream stages, and there are no measurable effects of these diversions on the pumpage of ground water in the basin. Under optimum conditions of pumpage, diversions of streamflow could probably be increased to about three times present annual rates without reducing average base flows. Although present diversions of ground water in Reading reduce base flows in the Ipswich River by a considerable amount, additional diversions of ground water could be readily sustained in any part of the river basin if made during high-flow periods.

Investigations made during the study of the coastal region of Massachusetts by the New England-New York Inter-Agency Committee (1955, p. V-59 and VII-3) indicated that no new power, conservation-storage, or flood-control sites are feasible in the Ipswich basin. Although relatively small local conservation or flood-control projects are not ruled out by this finding, it is likely that future waterresources development in the Ipswich River basin will be undertaken mainly for municipal and industrial water supply and that this development will proceed largely through expansion of local storage facilities and the optimum utilization of water under existing hydrologic conditions.

Effective use of both ground water and surface water in the basin will depend on the extent to which all possible hydrologic factors are taken into account in the planning. The abundance of water in the river basin has made possible a relatively uncoordinated approach to water-supply problems by individual communities, but it is apparent that increasing development will bring increasing problems unless planning is expanded to include a basin-wide approach to the use of water resources. In particular, future development will necessitate a more complete appraisal of the vast storage reservoir represented by the swamps of the basin. Expanding urbanization in the Ipswich River basin, at the same time as it increases the demands on water resources, will inevitably restrict the functioning of wetlands in the hydrologic system. Other factors of the hydrologic system will be altered as the result of changes in land use, the building of new high- 
ways, the restriction of stream channels, and developments as yet unforeseen. It is apparent, therefore, that a better understanding of the relationships among all the factors of the hydrologic system will help to insure that future water needs are met as effectively and economically as possible.

\section{PRINCIPAL CONCLUSIONS}

1. An abundance of ground water is available for use in the Ipswich River basin. It is estimated that withdrawal of ground water could be sustained under present conditions at about five times the 1960 rate of $4.9 \mathrm{mgd}$. Most of this increase would necessarily occur in the lower Ipswich River basin.

2. Conditions appear to be favorable for increased withdrawal of ground water in many places throughout the basin. One or more favorable sites exist in each of the 10 communities that occupy the major part of the river basin.

3. The principal sources of present and future ground-water supplies are the stratified glacial deposits that underlie most lowlands in the drainage basin. However, the yield at any given site depends on the thickness and distribution of permeable materials.

In the Wilmington-Reading area, the chances of locating thick, permeable materials appear to be best in the Martins Brook-Skug River drainage basins. In the lower Ipswich River basin, the most favorable areas appear to be the Wenham Swamp-Pleasant Pond area, the Miles River subbasin, and the central reaches of the Ipswich River valley. In the areas listed above, as well as in others described in this report and the Wilmington-Reading report (Baker and others, 1964), careful exploration and testing are necessary in order to locate the most permeable zones in potential aquifers.

4. Swamp deposits occupy large areas of the basin and exert a strong influence on streamflow characteristics, evapotranspiration, and ground-water recharge. The lowland swamps, the underlying stratified drift, and the principal streams of the area form the three major components of a complex hydrologic system. Although the function of swamps in the hydrologic system is imperfectly understood, swamp areas are known to store large amounts of water throughout the year, and thereby retard stream runoff and provide potential recharge for ground-water reservoirs.

5. Surplus streamflow drains from the basin during the late fall, winter, and spring seasons. However, the usable water supply of the basin is basically limited by the rate at which water can be obtained from ground- and surface-water storage during the remainder of each year when little recharge occurs and stream- 
flow declines. The period during which little recharge occurs may be nearly 180 days, and conditions of critically low streamflow have lasted as long as four months.

6. Further development of water supplies from streamflow could be sustained on a year-round basis in the downstream reaches of the river. At the South Middleton gaging station, flows averaging only $1 \mathrm{mgd}$ for a period of 60 days have a 24 percent probability of occurrence each year, whereas at the gaging station near Ipswich, flows averaging only $1 \mathrm{mgd}$ for a period of 60 days have not occurred during the past 30 years. Greatly increased amounts of water could be taken from the Ipswich River during high-flow periods in both the Wilmington-Reading and the downstream areas.

7. The quality of water in the Ipswich River basin is generally satisfactory for domestic as well as for many commercial needs. In comparison with most ground and surface water throughout the nation, the water is relatively soft and possesses few objectionable constituents. Iron and manganese are elements most commonly present in objectionable amounts.

8. Future changes which will accompany the rapidly increasing urbanization of the river basin will greatly affect the hydrologic regimen in the basin. The drainage or filling of swamps, the construction of highways and housing developments, and many other changes in land use will tend to increase the cost and difficulty of obtaining future water supplies. Specifically, in addition to the decrease in areas available for water development, the tendency will be toward more rapid stream runoff, higher peak flows, lower base flows, less ground-water storage, and less recharge to aquifers.

9. The complex relationships that exist among the many elements of hydrology in the river basin imply the necessity for a basinwide approach to hydrologic problems and a regard for the inseparable nature of ground- and surface-water resources.

\section{SELECTED REFERENCES}

American Society of Civil Engineers, 1953, Report of the subcommittee on the joint division committee on floods: Am. Soc. Civil Engineers Trans., v. $118, \mathrm{p}$ 1220-1230.

Baker, J. A., 1960, Wetland and water supply : U.S. Geol. Survey Circ. 431, 3 p.

1964, Ground-water resources of the Lowell area, Massachusetts : U.S. Geol. Survey Water-Supply Paper 1669-Y, 37 p.

Baker, J. A., Healy, H. G., and Hackett, O. M., 1964, Geology and ground-water conditions in the Wilmington-Reading area. Massachusetts: U.S. Geol. Survey Water-Supply Paper 1694. 
Baker, J. A., and Sammel, E. A., 1961, Records and logs of selected wells and test holes, chemical analyses of water, and water levels in observation wells in the Wilmington-Reading area, Massachusetts: U.S. Geol. Survey open-file rept., $50 \mathrm{p}$.

Bloom, A. L., 1960, Late Pleistocene changes of sea level in southwestern Maine : Augusta, Maine, Dept. Econ. Devel., 143 p., 5 maps, 7 figs.

Bradley, E., 1964, Ground-water resources of southeastern New Hampshire: U.S. Geol. Survey Water-Supply Paper 1695, 80 p.

Brashears, M. L., Jr., 1941, Cooperative ground-water investigations in Massachusetts : New England Water Works Assoc. Jour., v. 56, no. 2, p. 152-156.

1944, Ground-water studies in northeastern Massachusetts: New England Water Works Assoc. Jour., v. 58, no. 4, p. 307-316.

Brown, T. C., 1932, Late Wisconsin ice movements in Massachusetts : Am. Jour. Sci., ser. 5, v. 23-24, no. 137, p. 462-468.

Byers, D. S., 1959, Radiocarbon dates from the Bull Brook site, Massachusetts : Am. Antiquity, v. 24, no. 4 , pt. 1, p. 427-429.

California State Water Pollution Control Board, 1952, Water quality criteria: Sacramento, Calif., pub. 3, 512 p.

Castle, R. O., 1958, Surficial geology of the Lawrence quadrangle, MassachusettsNew Hampshire: U.S. Geol. Survey Geol. Quad. Map GQ-107. 1959, Surficial geology of the Wilmington quadrangle, Massachusetts : U.S. Geol. Survey Geol. Quad. Map GQ-122.

Chute, N. E., and Nichols, R. L., 1941, The geology of the coast of northeastern Massachusetts : Massachusetts Dept. Public Works-U.S. Geol. Survey Coop. Geol. Proj., Bull. 7, 48 p.

Chute, N. E., 1960, Glacial Geology of the Mystic Lakes-Fresh Pond area, Massachusetts : U.S. Geol. Survey Bull. 1061-F, p. 187-216.

Clapp, C. H., 1921, Geology of the igneous rocks of Essex County, Massachusetts : U.S. Geol. Survey Bull. 704, 132 p.

Collins, W. D., 1925, Temperature of water available for industrial use in the United States : U.S. Geol. Survey Water-Supply Paper 520-F, p. 97-104.

Commonwealth of Massachusetts, 1955, Special report of the Department of Public Works relative to the drainage of swamp lands in the town of Wilmington and for such other improvements in the Ipswich River as may be necessary therefor : Commonwealth Massachusetts, House doc. 2391.

Crosby, I. B., 1937, Ground-water conditions of parts of Middlesex, Worcester and Norfolk Counties in the buried valleys of the preglacial Merrimack, Sudbury and Charles Rivers: Ann. Rept. Dept. Public Health, Commonwealth Massachusetts, Public doc. 34, year ending Nov. 30, 1937, p. 219-224.

1939, Ground water in the preglacial buried valleys of Massachusetts: New England Water Works Assoc. Jour., v. 53, no. 3, p. 372-383.

1945, Glacial erosion and the buried Wyoming valley of Pennsylvania: Geol. Soc. America Bull., v. 56, p. 389-400.

Crosby, W. O., 1899, Geoological history of the Nashua Valley during the Tertiary and Quaternary periods : Technol. Quart. v. 16, p. 64-92.

Currier, L. W., 194la, Disappearance of the last ice sheet in Massachusetts by stagnation zone retreat [abs.] : Geol. Soc. America Bull., v. 52, no. 12, pt. 2, p. 1895.

194lb, Tills of eastern Massachusetts [abs.]: Geol. Soc. America Bull., v. 52, no. 12, pt. 2, p. 1895-1896.

Currier, L. W., 1947, Granitization and its significance as a regional metamorphic process in New England: Washington Acad. Sci. Jour., v. 37, no. 3, p. 75-86. 
Ourrier, L. W., and Jahns, R. H., 1952, Geology of the "Chelmsford Granite" area : Geol. Soc. America Guidebook for Field Trips in New England, p. 105-117.

Cushman, R. V., Allen, W. B., and Pree, H. L., Jr., 1953, Geologic factors affecting the yield of rock wells in southern New England: New England Water Works Assoc. Jour., v. 67, no. 2, p. 77-95.

Dachnowski, A. P., 1926, Factors and problems in the selection of peat lands for different uses : U.S. Dept. Agriculture, Dept. Bull. 1419, 23 p.

Dachnowski-Stokes, A. P., 1935, Peat land as a conserver of rainfall and water supplies : Ecology, v. 16, p. 173-177.

Department of the Army, 1957, Wells : Dept. Army Tech. Manual TM5-297, $264 \mathrm{p}$.

Ellis, E. E., 1909, A study of the occurrence of water in crystalline rocks, in Gregory, H. E., 1909, Underground water resources of Connecticut: U.S. Geol. Survey Water-Supply Paper 232, p. 54-103.

Emerson, B. K., 1917, Geology of Massachusetts and Rhode Island: U.S. Geol. Survey Bull. 597, 289 p.

Fenneman, N. M., 1938, Physiography of the Eastern United States : New York, McGraw-Hill, 714 p.

Ferris, J. G., 1950, A quantitative method for determining ground-water characteristics for drainage design: Agr. Eng., v. 31, no. 6, p. 285-289, 291.

Flint, R. F., 1953, Probable Wisconsin substages and Late-Wisconsin events in northeastern United States and southeastern Canada: Geol. Soc. America Bul., v. 64, no. 8, p. 897-919.

Green, A. R., 1964, Magnitude and frequency of floods in the United States, pt. 1-A : U.S. Geol. Survey Water-Supply Paper 1671, 260 p.

Harold, L. L., 1934, Relation of streamflow to ground-water levels : Am. Geophys. Union Trans., v. 15, no. 2, p. 414-416.

Hem, J. D., 1959, Study and interpretation of the chemical characteristics of natural water: U.S. Geol. Survey Water-Supply Paper 1473, 269 p., 2 pl.

Jahns, R. H., 1941, Stratigraphy of the Lowell-Fitchburg area, Massachusetts [abs.] : Geol. Soc. America Bull., v. 52, no. 12, pt. 2, p. 1910-1911.

1942, Origin of the Ayer granodiorite in the Lowell area, Massachusetts : Am. Geophys. Union Trans., v. 23, no. 2, p. 341-342.

1943, Sheet structure in granites; its origin and use as a measure of glacial erosion in New England : Jour. Geol., v. 51, p. 71-98.

King, F. H., 1892, Observation and experiments on the fluctuations in the level and rate of movement of ground water on the Wisconsin Agricultural Experiment Station Farm at Whitewater, Wisconsin: U.S. Dept. Agriculture Weather Bur. Bull 5, p. 1-74.

Knox, C. E., 1956, Index of surface-water records to September 30,1955 , pt. 1 , North Atlantic slope basins : U.S. Geol. Survey Circ. 381, $30 \mathrm{p}$.

Knox, C. E., and Soule, R. M., 1949, Hydrology of Massachusetts: U.S. Geol. Survey Water-Supply Paper 1105, pt. 1, 240 p.

LaForge, L., 1932, Geology of the Boston area, Massachusetts : U.S. Geol. Survey Bull. 839, 105 p.

I,angbein, W. B., and Iseri, K. T., 1960, General introduction and hydrologic definitions, pt. 1 of Manual of hydrology : General surface-water techniques : U.S. Geol. Survey Water-Supply Paper 1541-A. 29 p.

Latimer, W. J., and Lanphear, M. O., 1929, Soil survey of Middlesex County, Massachusetts : U.S. Dept. Agriculture Soil Survey Rept. 26, ser. 1924, 58 p.

Lautzenheiser, R. E., 1959, Climate of Massachusetts: U.S. Weather Bur., Climatography of the United States, no. 60-19, 16 p. 
Lee, C. H., 1934, The interpretation of water levels in wells and test holes : Am. Geophys. Union Trans., v. 15, no. 2, p. 540-554.

Lee, F. W., Farnham, F. C., Raspet, A., and Currier, L. W., 1940, The seismic method for determining depths of bedrock as applied in the Lowell quadrangle, Massachusetts : Mass. Dept. Public Works-U.S. Geol. Survey Coop. Geol. Proj. Spec. Paper 3, 46 p.

MacConnell, W. P., 1957, Cover mapping Massachusetts from aerial photographs : Syracuse, N.Y., Soc. Am. Foresters Proc., p. 159-162 [repr.]

Manson, P. W., and Miller, D. G., 1954, Groundwater fluctuations in certain open and forested bogs of northern Minnesota : Univ. Minnesota, Agr. Expt. Sta. Tech. Bull. 217, 29 p.

Massachusetts Cooperative Wildlife Research Unit, 1959, Classification of land cover types by towns in Middlesex County : Univ. Massachusetts, Coop. Ext. Service, $59 \mathrm{p}$.

Meinzer, O. E., 1923, The occurrrence of ground water in the United States with a discussion of principles: U.S. Geol. Survey Water-Supply Paper 489, 321 p., 31 pls.

1932, Outline of methods for estimating ground-water supplies : U.S. Geol. Survey Water-Supply Paper 638-C, p. 99-144.

Meinzer, O. E., and Stearns, N. D., 1929, A study of ground water in the Pomperaug Basin, Connecticut: U.S. Geol. Survey Water-Supply Paper 597-B, p. 73-146.

Mills, F. S., 1903, The delta-plain at Andover, Mass. : Am. Geologist, v. 32, p. 162-170.

New England-New York Inter-Agency Committee (NENYIAC), 1955, The resources of the New England-New York region, Massachusetts Coastal Area : pt. 2, chap. 16.

Oldale, R. N., 1962, Surficial geology of the Reading quadrangle, Massachusetts : U.S. Geol. Survey Geol. Quad. Map GQ-168.

1964, Surficial geology of the Salem quadrangle, Massachusetts: U.S. Geol. Survey Geol. Quad. Map GQ-271.

Piper, A. N., 1944, A graphic procedure in the geochemical interpretation of water analyses: Am. Geophys. Union Trans., v. 25, pt. 6, p. 914-923.

Renfro, G. M., Jr., 1955, Applying water under the surface of the ground, in Yearbook of Agriculture, 1955: Washington, U.S. Govt. Printing Office, p. 273-278.

Roe, H. B., 1943, The soil moisture and cropping problem on peat and muck lands in the northern United States: Agr. Exp. Sta., Univ. Minnesota Dept. Agr. Sci. Paper 2032, 72 p., pub. by U.S. Dept. Agriculture, Soil Conserv. Service.

Sammel, E. A., 1963, Surficial geology of the Ipswich quadrangle, Massachusetts : U.S. Geol. Survey Geol. Quad. Map GQ-189.

Sammel, E. A., and Baker, J. A., 1962, Records of wells, materials tests, and chemical analyses of water in the lower Ipswich River basin, Massachusetts : U.S. Geol. Survey open-file rept., $47 \mathrm{p}$.

Sears, J. H., 1905, The physical geography, geology, mineralogy, and paleontology of Essex County, Massachusetts: Salem, Mass., Essex Inst., $418 \mathrm{p}$.

Stearns, N. D., 1927, Laboratory tests on physical properties of water-bearing materials: U.S. Geol. Survey Water-Supply Paper 596-F, p. 121-176, pls. 11-13.

Stephens, J. C., 1955, Drainage of peat and muck lands, in Yearbook of Agriculture, 1955 : Washington, U.S. Govt. Printing Office, p. 539-557. 
Theis, C. V., 1953, The relation between the lowering of the piezometric surface and the rate and duration of discharge of a well using ground-water storage: Am. Geophys. Union Trans., v. 16, pt. 2, p. 519-524.

Theis, C. V., and others, 1954, Estimating transmissibility from specific capacity : U.S. Geol. Survey open-file rept., $11 \mathrm{p}$.

Thomson, M. T., Gannon, W. B., Thomas, M. P., Hayes, G. S., and others, 1964, Historical floods in New England, U.S. Geol. Survey Water-Supply Paper 1779-M, $105 \mathrm{p}$.

U.S. Department of Agriculture, 1957, Hydrology : U.S. Agriculture, Soil Conser. Service, Eng. Handb., sec. 4, supp. A, 343 p.

U.S. Geological Survey, 1930-1960, Surface-water supply of the United States, pt. 1, North Atlantic slope basins : U.S. Geol. Survey Water-Supply Papers 696, $711,726,741,756,781,801,821,851,871,891,921,951,971,1001,1031,1051$, $1081,1111,1141,1171,1201,1231,1271,1331,1381,1431,1501,1551,1621$, and 1701.

U.S. Geological Survey, 1939-1957, Water levels and artesian pressure in observation wells in the United States, pt. 1, Northeastern States: U.S. Geol. Survey Water-Supply Papers 886, 906, 936, 944, 986, 1016, 1023, 1071, 1096, 1126, 1156, 1165, 1191, 1221, 1265, 1321, 1404, and 1537.

U.S. Public Health Service, 1946, Public Health Reports: reprint 2697.

1962, Drinking water standards : U.S. Public Health Service Publ. 956, 61 p.

U.S. Weather Bureau, 1926-60, Climatological data. 
INDEX

[Italic page numbers indicate major references]

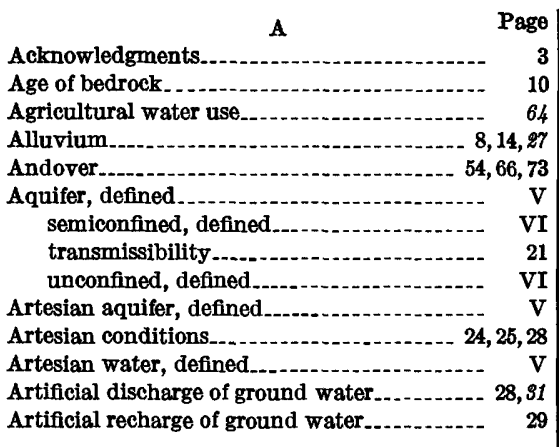

B

Base flow $30,69,72,74$

Base runoff VII, 39, 47, 52, 53

Beach and dune deposits

Beaver Pond

Beck Pond.

Bedrock wells in

Beverly ............ 6,44,45, 56 municipal water supplies............... 63

Black Brook

Boston Brook.

Boston Hill. well in 11

Boxford. $42,43,54,66,73$

Brackish water

Buried valleys ground water in

Burleys Corner.

\section{C}

Capillary fringe.

Castle Hill.

Cedar Swamp

Central area.

Chebacco Lake.

Chemical constituents in ground water.

Climate

Climatic year.

Coefficient of permeability........ VI, 16, 19, 21, 23,27

Coefficient of transmissibility.................. VIII

Conclusions.

Confined aquifer.

Consolidated rocks.

Consumption.

See also Use of water.

Contaminants.

Contamination hazard, dug wells
D

Page

Danvers................ 43, 56, 57, 66, 73 municipal water supply......-........... 36, 44

Danvers-Middleton municipal wells...-.-... $\quad 30$

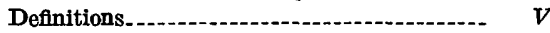

Delta structure.......-...-... 18

Depth, bedrock

water-_... 11 See also under particular deposit.

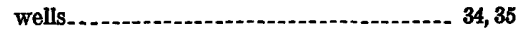

Development of ground water................. 38

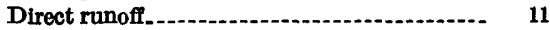
See also Runoff.

Discharge. See also Artificial discharge. ground-water.-......................... VI, 62 rate in bedrock............................ 11 surface-water.......................... VI

Dissolved solids. Diversion............... VI, 28, 47, 66, 63, 64, 65, 72, 74

Domestic water supply.................... $\$ 8$

Domestic water use_.......................... 64

Drainage basin, defined...... VI

Drainage channels............................. 54

Drainage divide, defined.................. VI

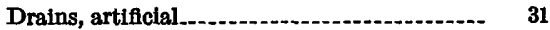

Drawdown

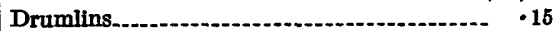

Dunes_............................................ 14, 27

See also Beach and dune deposits.

$\mathbf{E}$

Eastern area-.......-.-..- 44

Effective recharge............... $\$ 9$ See also Recharge.

Evapotranspiration.-........-...-.-.-.-... VI,

$11,26,28,30,31,39,41,46,57,75$ F

Fertilizer, source of contamination............. 58

Fish Brook...................................... 20

Flood-frequency curves........ 55

Floods.-...... 64

Flow-duration curves.......................... 47,51

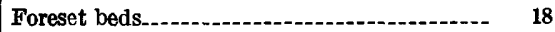

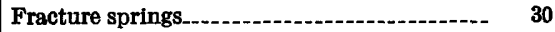

Frequency curves, base runoff-........-...-. $\quad 53$

\section{G}

Gage height, defined........-... VII

Geologic unit, defined............. VI

hydrologic characteristics.-............... 7

Grain size............ 18, 23

Gravel cap........................ 19

34 Gravel-packed wells._._. 21, 35, 36 


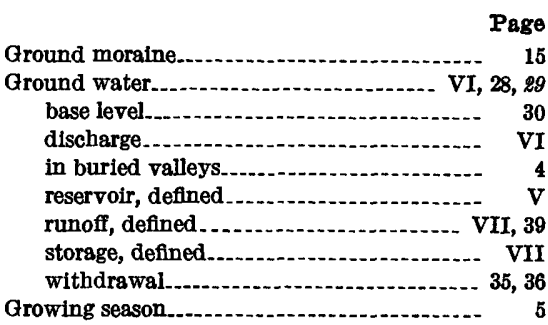

\section{H}

Hamilton municipal water supply

$43,45,65,66,73$ wells.

36,44 olt Hill

23,24

Hydraulic gradient......................... VI, 28, 30

Hydrograph.................. VI, 31

Hydrology. . . . .

bedrock. ............. 10

ice-contact deposits...................... 19

marine deposits................-

outwash deposits.

swamp deposits.

till

unconsolidated deposits

Ico-channel fillings hydrology

Industrial waste

Industrial water use

Infiltration.

Intergranular openings

Investigations, previous. purpose and scope

Ipswich

annual runoff

$8,14,16,21,29,39,42,44,45$

$43,44,45,47$

gaging station municipal water supply $45,48,51,52,57,71,73$ wells

Ipswich River. $6,16,42,43,44,45,56,73$

dam at.

flooding

ground water near

pollution.

Iron concentrations.

\section{$\mathbf{J}$}

Joints, ground water in

\section{K}

Kames

$\mathbf{L}$

Little Neck

Longham Reservoir

Low-flow frequency

Lubber Brook. pollution in

Lynn municipal water supplies
Manganese concentrations

Marine deposits.................... 8, 14, 17, 20,44

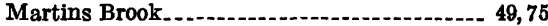
pollution in

Martins Brook valley....................... 24

Massachusetts Department of Public Health, cited........... 63

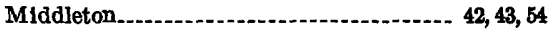
gage at.................... 48

municipal water supply.................. 44

test hole................................ 17

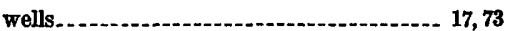

Middleton Pond............... 66

Miles River............................ 23, 45, 73, 75

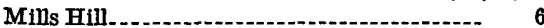

Mosquito Brook

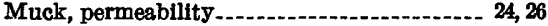

Municipal water supply.............. 30, $55,36,44,63$

\section{$\mathbf{N}$}

Natural discharge of ground water

New England Interstate Water Pollution Control Commission, quoted....- 63

New England-New York Inter-Agency Committee, cited..................... 62, 65, 74

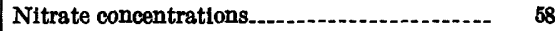

North Andover........................... 42, 66

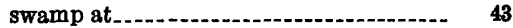

well

North Reading

municipal supply

well............ 20

Norwood Pond.-..-_.

Outwash deposits........... 8, 14, 17, $20,29,39,44,47$ hydrology

Palmer State Park.

Parker State Forest_. .

Partial-record station, defined............. VI

Particle-size distribution. ................... 14, I8 See also Grain size.

Peabody-........ 43, 56, 64, 65 municipal water supply.................. 36, 63

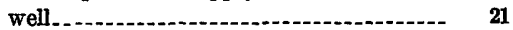

Peak discharges of streamflow -........... 45

Peak-storm runoff-............... 26

Peat.-._-_..._.

Permeabllity....................... 14, 21

bedrock.................................. 10

coefficient................ VI, 16, 19, 21, 23, 27

defined..................................... VI

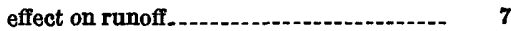

horizontal........... 23, 25

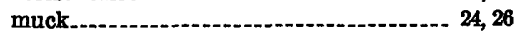

peat.

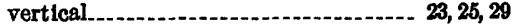

See also under particular deposit.

pH.-1.-.... VI

6, 64, 65 Pleistocene.

63 Pocahontas Spring-...-..- 35 
Pollution

Ponded water.

Ponds, potential water sources

Population growth.

Porosity.

Precipitation

Public supply of water

Putnamville Reservoir

Pye Brook

Q

Quality of water

\section{$\mathbf{R}$}

Reading. municipal water suppiy wells.

Recession curve, defined $30,33,48,73$

Recharge VII, 26, $29,39,70$ rate in bedrock rejected.

Recovery methods of ground water

Recreation

Reservoir, ground-water

Rock types

Rowley municipal water supply

Runoff. VII, 11, 26, 28, 30, 39, 46, 69 annual. effect of permeability on peak storm

Salem municipal water supplies

$56,64,65$

Salt water-

Seepage springs

Semiconfined aquifer

Sewage, source of contamination

Skug River

Snowfall records

Soil moisture

Soll zone percolation

Sorting coefficient.

South Middleton annual runoff

gages at

gaging station

stage hydrograph

Specific capacity

Specific yield

Springs as water source

Stage, defined.

Storage

bases for estimates

in bedrock

Storm seepage

Storms.

Stratified deposits

sources of future ground water

Stratified drift

Stratigraphy, defined

Stream channel deepening, proposed

Streamfiow.
62
8

$\begin{array}{rr}\text { Temperature, cycle. } & 5 \\ \text { water... } & 61 \\ \text { Theis, C. V., and others, cited.... } & 19\end{array}$

Theis, C. V., and others, cited......

Till................. 8, 14,15,29

Topography _......................... 5

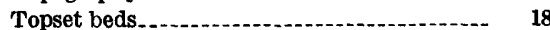

Topsfield.................. 20,43,73

municipal water supply ................... 36, 44

well ................... 33

Transmissibility

\section{$\mathrm{U}$}

Unconfined aquifer....................... VI Unconsolidated rocks.................. VIII, 7, 14 Unregulated streams. U.S. Public Health Service limits recom-

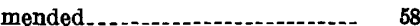

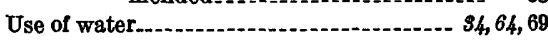

\section{W}

Waste water

Water-level fluctuation............................ 31

Water loss.............................. VIII, 57

Water-resources development_...-.......... 69

Water table, defined............... VIII

Water-table aquifer....................... VI, VIII

Water use........................... $\$ 4,64,69$

Water year, defined......................... VIII

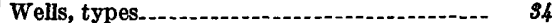

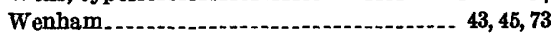

municlpal water supply................ 36, 44

well......................................... 24

Wenham Lake............ 6, 44, 66

Wenham Swamp........... 24,44, 57, 75

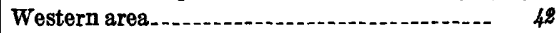

Wills Brook

Wilmington................... 20,65

municipal water supply................... $\quad 36$

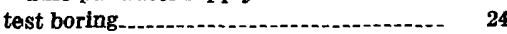

wells........................................ 33

Wilmington-Reading area, ground-water con-

Wind deposits...........................

Wisconsin ice.......................... 15

Withdrawal of ground water._._._._._._. 35,36

feasibility of increasing.

36,41

VIII

30

Yields

\section{$\mathbf{Y}$}

See also under particular deposit.

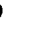

73

(1)

